WAPD-TM-1063

\title{
BRAZING FIXTURE MATERIALS FOR FABRICATION OF AM-350 FUEL ROD SUPPORT GRIDS (LWBR DEVELOPMENT PROGRAM)
}

\author{
R.J. Towner
}

August 1976

Contract E(36-1)-GEN-14

Printed in the United States of America

Available from the

National Technical Information Service

U. S. Department of Commerce 5285 Port Royal Road

Springfield, Virginia 22151

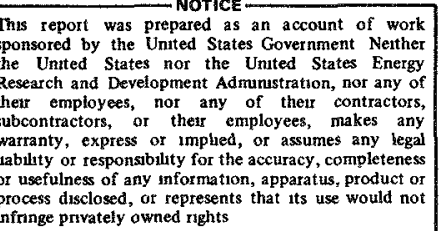

process disclosed, information, apparatus, product or infinge privately owned nights

\section{NOTE}

This document is an interım memorandum prepared primarily for internal reference and does not represent a final expression of the opinion of Westinghouse. When this memorandum is distributed externally, it is with the express understanding that Westinghouse makes no representation as to completeness, accuracy, or usability of information contained therein

BETTIS ATOMIC POWER LABORATORY WEST MIFFLIN, PENNSYLVANIA

Operated for the U. S. Energy Research and Development Administration by WESTINGHOUSE ELECTRIC CORPORATION 


\section{NOTICE}

This report was prepared as an account of work sponsored by the United States Government. Neither the United States, nor the United States Energy Research and Development Ådministration, nor any of their employees, nor any of their contractors, subcontractors, or their employees, makes any warranty, express or implied, or assumes any legal liability or responsibility for the accuracy, completeness or us efulness of any information, apparatus, product or process disclosed, or represents that its use would not infringe privately owned rights. 


\section{DISCLAIMER}

This report was prepared as an account of work sponsored by an agency of the United States Government. Neither the United States Government nor any agency Thereof, nor any of their employees, makes any warranty, express or implied, or assumes any legal liability or responsibility for the accuracy, completeness, or usefulness of any information, apparatus, product, or process disclosed, or represents that its use would not infringe privately owned rights. Reference herein to any specific commercial product, process, or service by trade name, trademark, manufacturer, or otherwise does not necessarily constitute or imply its endorsement, recommendation, or favoring by the United States Government or any agency thereof. The views and opinions of authors expressed herein do not necessarily state or reflect those of the United States Government or any agency thereof. 


\section{DISCLAIMER}

Portions of this document may be illegible in electronic image products. Images are produced from the best available original document. 
II EXPERIMENTAL

A Description of Brazing Cycles in Processes $M$ and $A$

B Thermal Expansion and Contraction During the Brazing Cycle

1 Process $M$

2 Process A

C Dimensional Changes Due to Brazing Cycles

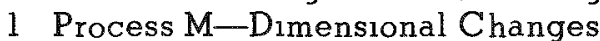

a Bar and Plate Specimens (Process $M$ )

b AM-355 Machined Fixture Plates (Process M)

c Dilatometer Test Specimens (Process M)

d Dimensional Restoration Thermal Treatment (Process $M$ )

e Metallography (Process M)

$f$ Dimensional Stabilization Thermal Treatment Experiment (Process M)

2 Process $A$-Dimensional Changes

a Bar and Plate Specimens (Process $A$ )

b Machined Fixture Plates (Process A)

c Dilatometer Test Specimens (Process $\mathbb{A}$ )

d Metallography (Process A)

D Flatness Changes Due to Brazing Cycles

1 Process M-Flatness Changes

a Bar and Plate Specimens (Process M)

b AM-355 Machined Fixture Plates (Process M)

2 Process A-Flatness Changes

a Bar and Plate Specimens (Process A)

III DISCUSSION

IV CONCLUSIONS

A Candidate Brazıng Fixture Material Characterıstıcs

B Procedures for Development of Brazing Fixtures

1 Procurement of Materials

2 Evaluation of Material Prior to Design and Machining of Fixtures

3 Layout and Machining of Fixture Plates, Dimensional Measurements, and Thermal Treatments Durnng Service

C Chemistry and Heat Treatment Information on Materials Investigated 10

V EXPERIENCE WITH PROCESS M DEVELOPMENT BRAZING FIXTURE MATERIALS 10

A Process M-M2 Tool Steel Brazing Fixture Mismatch with Grid 10

B Process M-AM-355 Brazing Fixture Dimensional Stability 10

C Process A-N $\mathrm{N}_{1} \mathrm{CrFe}$ Alloy 600 Brazing Fixtures 10

VI EXPERIENCE WITH LWBR PRODUCTION BRAZING FIXTURES 10

VII ACKNOWLEDGMENTS 11

VIII REFERENCES 


\section{LIST OF ILLUSTRATIONS}

3 Dilatometer Tests for Process M Brazing on Low-Carbon, Low-Nitrogen AM-350 Plate versus AM-350 Sheet

Dilatometer Tests for Process M Brazing on M2 Tool Steel Plate versus AM-350 Sheet

Dilatometer Tests for Process $\bar{A}$ Brazing on $\mathrm{NiCrFe}$ Alloy 600 Plate versus AM-350 Sheet

6 Process M-Dimensional Change Tests on Low-Carbon, Low-Nitrogen AM-350 Plate Fixture Material versus Braze Cycles

Process M-Dimensional Change Tests on AM-355 and M2 Tool Steel Fixture Materials versus Braze Cycles

Microstructure Showing Delta Ferrite Stringers in a Longitudinal Section of AM-355 Plate 3/4-Inch Thick (Heat 27205) in the As-Received Condition

Microstructure Showing Remnants of Delta Ferrite Stringers in a Longitudinal Section of AM-355 Plate 3/4-Inch Thick (Heat 27205) After Fourth Process M Braze

Microstructure Showing Delta Ferrite Stringers in a Transverse Section of Extra Low-Carbon AM-350 Bar 1 3/4-Inch $\times 1$ 3/4-Inch Thick (Heat 7C547) in AsReceived Condition (Top) and After Third Process M Braze (Bottom)

11 Microstructure Showing Various Types and Sizes of Carbide Particles and Very Fine-Grain Matrix in a Longitudinal Section of M2 Tool Steel Plate 3/4-Inch Thick (Heat 27433) in As-Received Condition (Top) and After Fourth Process M Braze (Bottom)

Microstructure Showing Remnants of Delta Ferrite Stringers in Longitudinal (Top) and Transverse (Bottom) Sections of AM-355 Plate 3/4-Inch Thick (Heat 27205) After 6 Hours at $2150 \mathrm{~F}$ with Sub-Zero Cool

13 Microstructure Showing Delta Ferrite Stringers (Top) As-Received, and Remnants of Stringers (Bottom) After 6 Hours at 2150F with Sub-Zero Cool in Longitudinal Sections of Low-Carbon, Low-Nitrogen AM-350 Plate 3/4-Inch Thick (Heat 7C601)

14 Microstructure Showing Grain Size of Matrix in a Longitudinal Section of $\mathrm{NiCrFe}$ Alloy 600. Plate 3/4-Inch Thick (Heat NX0895) in As-Received Condition (Top) and After Third Process A Braze (Bottom)

Process A-Dimensional Change versus Braze Cycles of Production Fixture Top Plate BA-2, S/N-01

Process $\mathrm{A}-$ Dimensional Change versus Braze Cycles of Production Fixture Bottom Plate BA-2, S/N-01

Process A-Dimensional Change versus Braze Cycles of Production Fixture Top Plate BA-1, S/N-02 


\section{LIST OF TABLES}

Carbon and Nitrogen Contents of AM-350 Sheet Specimens Investigated in the Dilatometer Tests Performed at the Battelle Memorial Institute

2 Process M-Dimensional Change Tests on Bar and Plate Specimens versus Braze Cycles

Process M-Dimensional Change Tests on AM-355 Fixture Plates versus Braze Cycles

Process M-Comparison of Dimensional Change of Dilatometer Test Specimens and Plate Specimens versus Braze Cycles

Process M-Dimensional Restoration Thermal Treatment Experiments to Produce Expansion for Offsetting Cumulative Shrinkage

Process M-Examples of Dimensional Restoration Thermal Treatments for AM-355 to Produce Expansion for Offsetting Cumulative Shrinkage

Process M-Experiment on Dimensional Stabilization Thermal Treatment for Delta Ferrite Phase Morphology in AM-355 and AM-350

Process A-Dimensional Change Tests on Bar and Plate Specimens versus Braze Cycles

Process M-Flatness of Bar and Plate Specimens versus Braze Cycles

Process M-Flatness of AM-355 Fixture Plates versus Braze Cycles

Process A-Flatness of Bar and Plate Specimens versus Braze Cycles

12 Chemistry and Heat Treatment Information on Materials Investigated

13 Average Dimensional Changes from the Original As-Received Dimension of the AM-355 Brazing Fixture Plates

Dimensional Difference Between the Initial and Last Braze Cycle Measurements (Process $\bar{A}-\mathrm{NiCrFe}$ Alloy 600 Brazing Fixtures) 
Results are presented of an investigation of the thermal expansion and contraction anisotropy and dimensional stability characteristics of candidate brazing fixture materials for LWBR fuel rod support grid structures These characteristics are assessed in regard to their compatibility and usefulness with $A M-350$ grid material during two different brazing/fabrication processes $M$ and $A$ both of which involve 2070 to $2080 F$ brazing in vacuum Fixture materials evaluated for Process $M$ are AM-355 low-carbon low-nitrogen AM-350 and M2 tool steel NiCrFe Alloy 600 is evaluated for Process $A$ Subsequent experience with development and production brazing fixtures for full-size grids is summarized

\title{
BRAZING FIXTURE MATERIALS FOR FABRICATION OF AM-350 FUEL ROD SUPPORT GRIDS (LWBR DEVELOPMENT PROGRAM)
}

\author{
R J Towner
}

\section{INTRODUCTION}

This report presents the results of an investigation of the thermal expansion and contraction, anisotropy, and dimensional stabilıty characteristics of candidate brazing fixture materials for use at $2100 \mathrm{~F}$ These characteristics were assessed in regard to their dimensional compatibility and usefulness with $\bar{A} M-350$ stainless steel grid material during the brazing portion of two candidate brazing/fabrication processes, $M$ and $\AA$, for LWBR luel rod support grid structures Conclusions are drawn pertaining to selection and operational procedures during use of brazing fixture materials based on the results of this study

The need to characterize brazing fixture materials (by dilatometry in the longitudinal and transverse directions, and measurement for evidence of dimensional change or distortion after each thermal cycle) was recognized as part of the AM-350 grid dimensional control work program and also as part of the fixture program to assess if the number of braze cycles that a fixture could be used before it had to be discarded (useful lifetime) was limited Concurrently, the thermal expansion and contraction characteristics in Process $M$ of AM-350 sheet material containing three levels of carbon and nitrogen were obtained for evaluation by other investigators These data are used as a basis of comparison in this report

\section{EXPERIMENTAL}

\section{A. Description of Brazing Cycles in Processes $M$ and $\mathbf{A}$}

The brazing schedules in Processes $M$ and $A$ used for reference in this study are described below Brazing was performed in a vacuum furnace (pressure of $5 \times 10^{-4}$ torr or less at the brazing temperature)

The brazing portion of Process $M$ involved the following (1) start with the previously decarburized and sub-zero cooled low-carbon, lownitrogen AM-350 grid (assembled but unfixtured) in the martensitic condition, (2) position grid on the martensitic or ferritic fixture, which includes top and bottom plates with holes for $\mathrm{N}_{1} \mathrm{Cr} F e$ Alloy 600 slotted inserts to extend through for holding the grid, plus pins and spacers to maintain proper distance between fixture plates, $(3)$ heat to the $1825 \mathrm{~F}$ equilibration temperature and hold for 20 minutes in the austenitic region, (4) vacuum braze at 2070 to $2080 \mathrm{~F}$ for 4 to 6 minutes, (5) solution-treat at $1900 \mathrm{~F}$ for 1 hour, (6) triggeranneal (austente condition) at 1710F for 1 hour, (7) cool rapidly to $1100 \mathrm{~F}$ and continue cooling slowly to room temperature, and (8) remove the fixture from the grid

The brazıng portion of Process $\AA$ was as follows (1) start with undecarburized, solution-annealed AM-350 material in the austenitic condition which has been assembled into a grid, (2) position grid on an austenitic fixture, (3) heat to the $1825 \mathrm{~F}$ equilibration temperature and hold for 20 minutes, (4) vacuum braze at 2070 to $2080 \mathrm{~F}$ for 4 to 6 minutes, (5) cool rapidly to room temperature, and (6) remove the fixture from the grid

\section{B. Thermal Expansion and Contrac- tion During the Brazing Cycle}

Dilatometer tests were conducted up to $2070 \mathrm{~F}$ with a standard hold of 4 minutes, $+2,-0$ minutes at $2070 \mathrm{~F}$ in a vacuum of $5 \times 10^{-5}$ torr on 0250 inch-diameter by 2000 -inch-long specimens of 
candidate fixture materials The tests were performed at the Westinghouse Research and Development Center, using a high-temperature dilatometer (Reference 1) Constant heating and cooling rates of $126 \mathrm{~F}$ (7C) per minute were employed For Process $\mathrm{M}$ specimens, the standard sub-zero cool to $-100 F,+0 F,-25 F$ with a hold of 180 minutes \pm 10 minutes at $-100 \mathrm{~F}$ followed by warming to room temperature was applied after each dilatometer test to the brazing temperature (2070F) Calibration standard specimens were run both in vacuum in the high-temperature dilatometer to $2070 \mathrm{~F}$ and in argon in a quartz dilatometer to $1832 \mathrm{~F}(1000 \mathrm{C}$ ) according to ASTM-E-228 (Reference 2) The quartz dilatometer was also used for the sub-zero cools following each hightemperature run

\section{Process M}

In describing the results of dilatometer tests on candidate brazing fixture materials (performed at the Westinghouse Research and Development Center using constant heating and cooling rates), comparisons are made with dilatometric test results shown in Figure 1 on 0015 -inch-thick AM-350 sheet specimens (Heat 48836) taken in the transverse direction These tests, performed at the Battelle Memorial Institute using simulated Process $M$ heating and cooling rates (Reference 3 ), investigated the carbon and nitrogen contents listed in Table 1

All specimens were decarburized and sub-zero cooled at Bettis prior to testing at Battelle and were primarily martensitic at the beginning of the simulated vacuum braze (2075F)/heat treatment cycle in the dilatometer

Since the brazing fixture is removed from the grid after the braze and prior to the sub-zero cool, dilatometer curves in this report are provided only for the braze portion of the braze/heat treatment cycle The dimensional change effects of sub-zero cooling and tempering are presented in tabular form and discussed later in this report

The dilatometer results for AM-355 plate (Heat 27205) in the longitudinal direction starting with the martensitic condition (previously sub-zero cooled) are given in Figure 2 The thermal expansion to the braze temperature was indicated to be only $04 \mathrm{mll}$ per inch greater for the AM-355 than for 0043 percent $C$ and 0042 percent $N$ Type II AM-350 sheet On cooling to room temperature, the AM-355 plate showed only a very small amount of transformation to martensite-less than that of any AM-350 sheet material

Figure 3 shows the superimposed dilatometer curve for low-carbon, low-nitrogen (0 053 percent C, 0064 percent N) AM-350 plate (Heat 7C601) in the longitudinal direction starting with the martensitic condition (previously sub-zero cooled) and returning to room temperature The heating and cooling curves for the AM-350 plate material generally lie slightly below those for the 0043 percent $C$ and 0042 percent $N$ Type II sheet matenal At the 2070F braze tem perature, the test results indicated the plate material expanded approximately the same amount as the Type II AM-350 sheet material (withın $06 \mathrm{mll}$ per inch) On cooling to room temperature, the plate material underwent a degree of transformation to martensite which was less than that of the Types II and III sheet materials and about the same as the higher carbon and nitrogen Type I sheet material

Figure 4 compares M2 tool steel plate (Heat 27433) thermal expansion characteristics in the longitudinal direction with those for $\bar{A} \mathrm{M}-350$ sheet The M2 tool steel transformed rather abruptly to austenite at a higher temperature (1500 to $1600 \mathrm{~F}$ ) than the AM-350 at 1200 to $1400 \mathrm{~F}$ The contraction in the $\mathrm{M} 2$ tool steel due to transformation over this 1500 to $1600 \mathrm{~F}$ range was approximately $1 \mathrm{mil}$ per inch This led to the $\mathrm{M} 2$ being undersize by about $1 \mathrm{mil}$ per inch at $1600 \mathrm{~F}$ compared with the Type II AM-350 sheet Upon reaching the braze temperature, there was an indicated difference of only $05 \mathrm{mil}$ per inch between the M2 and the 0043 percent $C, 0042$ percent $N$ AM-350 $\AA$ rather abrupt expansion of 2 mils per inch occurred over the 750 to $600 \mathrm{~F}$ range during cooling of the $\mathrm{M} 2$ as austenite transformed to bainite At 600F this led to a mismatch of 3 mils per inch with the $\mathrm{M} 2$ being larger than AM-350 On further cooling from $600 \mathrm{~F}$ to room tem perature, a maximum mis match of 5 mils per inch developed between the M2 and AM-350 However, complete transformation of austenite to martensite in the AM-350, as shown by the Type III material, resulted in the $\mathrm{M} 2$ and the $\mathrm{AM}-350$ having essentially the same dimensions at room temperature This mismatch of the M2 with the incompletely transformed Type I and Type II AM-350 was about $3 \mathrm{mils}$ per $1 \mathrm{nch}$ and $1 \mathrm{mil}$ per $1 \mathrm{nch}$, respectively

Repeat dilatometer tests on the same longitudinal specimen, starting with the martensitic (sub-zero cooled) condition each time, ind cated that the thermal expansion on heating to $2070 \mathrm{~F}$ was within $05 \mathrm{mil}$ per $1 \mathrm{nch}$ of the previous run for each plate material (AM-355, low-carbon, low-nitrogen AM-350, and M2 tool steel) Furthermore, the $M_{s}$ (start of the austenite-to-martensite transformation) temperature on cooling was within $10 F$ of that for the previous run for $\bar{A} \mathrm{M}-355$ and AM-350 The austenite-to-bainite transformation on cooling M2 always ceased at 600F in repeat runs

Observations were made concerning anisotropy effects in the dilatometer tests For comparable starting conditions, the thermal expansion at $2070 \mathrm{~F}$ was within $05 \mathrm{mil}$ per inch in the longitudinal and transverse directions on each 
plate material (AM-355, low-carbon, low-nitrogen $A M-350$, and $\mathrm{M} 2$ tool steel) On cooling, the $\mathrm{M}_{\mathrm{s}}$ temperature of AM-355 was approximately $40 \mathrm{~F}$ higher in the transverse specimen than in the longitudinal specimen For $A M-350$, the $M_{s}$ was about 60F higher in the transverse than in the longitudinal specimen The M2 tool steel had the same austenite-to-bainite transformation temperature range in the transverse and longitudinal directions

The comparisons made in Figures 2, 3, and 4 indicate that M2 tool steel plate material matches the dimensions of AM-350 sheet material better than does low-carbon, low-nitrogen AM-350 or AM-355 plate when considering dimensions at both the brazing temperature and at room temperature for Process M (The AM-350 sheet starts through the Process $\mathrm{M}$ brazing cycle in the martensitic condition and is intended to end in the martensitic condition at room temperature where the brazing fixture is removed from the grid)

\section{Process $\mathbb{A}$}

Dilatometer test results for $\mathrm{N}_{1} \mathrm{CrFe}$ Alloy 600 brazing fixture material (performed at the Westinghouse Research and Development Center using constant heating and cooling rates) are compared with those for austenitic AM-350 sheet material (solution-annealed at 1900 to $1975 \mathrm{~F}$ by the vendor and not decarburized) in Figure 5 Also included in Figure 5 are data on AM-350 published by Allegheny Ludlum Steel Corporation (Reference 4) and data on $\mathrm{N}_{1} \mathrm{CrFe}$ Alloy 600 from The International Nickel Company (References 5 and 6)

The $\mathrm{N}_{1} \mathrm{CrFe}$ Alloy 600 plate (Heat NX0895) was tested in the longitudinal direcion starting with the mill-annealed condition On healing, there is a good match at the braze temperature between the thermal expansion for $\mathrm{N}_{1} \mathrm{CrFe}$ Alloy 600 and that for AM-350, the data for the latter being extrapolated to 2070F from 1710F On cooling, the dimensional match down to room temperature between the two materials is maintaned as long as the AM-350 remains austenitic and does not transform to martensite This transformation can be avoided by cooling rapidly from the brazing temperature to below the carbide precipitation range This minimizes carbide precipitation and keeps the $\mathbf{M}_{\mathrm{s}}$ temperature below room temperature

Four dilatometer tests on the same transverse specimen indicated that the individual values of thermal expansion at $2070 \mathrm{~F}$ were within $06 \mathrm{mil}$ per inch of each other for the $\mathrm{N}_{1} \mathrm{CrFe}$ Alloy 600 plate material

Concerning anisotropy effects, the longitudinal and transverse specimens from the plate were observed to give thermal expansion values within $04 \mathrm{mil}$ per inch of each other at $2070 \mathrm{~F}$

\section{Dimensional Changes Due to Brazing Cycles}

Bar and plate specimens of substantial size, representing various heats of candidate fixture materials, and actual machined AM-355 fixture plates for development grids were given thermal treatments and were measured dimensionally All thermal treatments, including sub-zero cooling, were performed in LWBR grid production facilities to simulate as closely as possible production conditions with regard to the facilities, specimen location and means of support in the vacuum furnace, and operating personnel The dimensions of the specimens were determined before and after thermal treatments by measurements made with a coordinate measuring machine (CORDAX) to the nearest $0.0001 \mathrm{inch}(0.1 \mathrm{mil})$. Dimensional change was calculated in units of mils per inch (0 $001 \mathrm{inch}$ per inch) with reference to the original dimensions of the as-recelved (as-machined) material The data presented in this report will indicate shrinkage by a minus sign and expansion by a plus sign in reference to the original dimensions.

In the case of the bar and plate specimens, dimensions were determined in terms of $\mathrm{X}$ and $\mathrm{Y}$ coordinate distances of machined holes (two holes in bar and eight holes in plate) with respect to a datum reference hole [In one case, however, the overall length and distance between machined flats in the diametrical direction of an AM-355 bar specimen (Heat 23326) was measured rather than hole distance.]

For machined fixture plates, such as the AM-355 top and bottom plates for the development seed grid, both hole distances with respect to a datum reference hole and overall length and width were measured Since the two methods of measurement gave comparable results, data from only one method usually will be reported For hole distance determinations, two adjacent holes at a minimum of nine different locations spaced across the length and width of the plate (making a total of 18 preselected holes minimum) covering edge and interior locations were measured each time. Overall dimensions were measured each time at three fiducial marks across the length and three fiducial marks across the width The $X$ and $Y$ coordinates were aligned longitudinally and transversely with respect to the direction of metal working; i.e., rolling direction. In the case of crossrolled plate, the last direction of rolling was designated the rolling direction

All dimensional change values reported are averages for changes occurring over a distance of 3 inches or greater, with the exception of those in the drametrical direction of the AM-355 13/8inch-diameter bar and the thickness direction of the low-carbon, low-nitrogen $\overline{A M}-350$ 1/2-inch $\times 3$-inch $\times 3$-inch plate. 


\section{Process $\mathbf{M}$-Dimensional Changes}

a Bar and Plate Specimens (Process $M$ )-The results of dimensional change tests conducted on bar and plate specimens to which the Process $M$ braze was applied are given in Table 2 and $F i g-$ ures 6 and 7

The AM-355 bars and plate were originally procured in the equalized and overtempered cond1tion Application of the Process $M$ braze and cooling to room temperalure resulted in little or no transformation of austenite to martensite in AM-355 with the result that the dimensions were generally 4 mils per inch or more undersize after the braze The sub-zero cool for 3 hours at $-100 \mathrm{~F}$ was necessary to complete the transformation to martensite The dimensional change noted after the braze plus sub-cool varied substantrally from specimen to specimen (heat to heat) The temper ( 3 hours at $1000 \mathrm{~F}$ ) produced relatively little dimensional change from the sub-cooled condition in measurements at room temperature

Cumulative shrinkage of $A M-355$ and lowcarbon, low-nitrogen $\overline{A M}-350$ plate matenal occurred in the length and width directions as a result of repeated brazes A cumulative expansion occurred in the thickness direction This may be seen by a comparison of dimensional change values (from the as-received condition) for the same thermally treated condition in successive braze cycles (refer to Table 2) Figure 6 illustrates the cumulative shrinkage effect for two thermally treated conditions (after brazes and after brazes plus sub-zero cools) by reference to the lowcarbon, low-nitrogen ĀM-350 plate, $1 / 2$ inch $\times 3$ inches $\times 3$ inches, used for the top plate of a GRIP-III fixture (Heat 7C600/7C601) Cumulative shrinkage of AM-355 round bar matenal occurred in the longitudinal direction, while cumulative expansion was experienced in the thickness (diametrical) direction This is illustrated by the behavior of Heat 23326, AM-355 bar in the brazed plus sub-zero cooled condition (refer to Table 2 and see Figure 7) $\bar{A}$ lso included in Figure 7 are dimensional change results in the length and width dimensions for Heat 27205, AM-355 plate specimen $3 / 4$ inch $\times 9$ inches $\times 9$ inches, Heat 27268, AM-355 bottom fixture plate for a 218-cell blanket array, and Heat 27433, M2 tool steel plate specimen $3 / 4$ inch $\times 9$ inches $\times 9$ inches The AM-355 plate materials tended to shrink in both the length and width dimensions with repeated braze cycles, while the $\mathrm{M} 2$ tool steel matenal did not (The Heat 27205 of AM-355 plate was rather unique in that it showed a significant net expansion after the first braze and after the first braze plus sub-zero cool compared to the asreceived condition, while other heats of AM-355 plate showed a very small expansion or a contrac- tion All of the AM-355 heats of material were procured in nominally the equalized and overtempered condition)

Small anisotropy effects were revealed in Heat 27205, AM-355 plate, after the first braze plus sub-cool and after successive cycles Directionality differences of about $05 \mathrm{mll}$ per inch were maintained while cumulative shrinkage was occurring in both the longitudinal (length) and transverse (width) dimensions The longitudinal dimension was always smaller than the transverse for the same thermal treatment in measurements at 70F

Heat 7C60l of low-carbon, low-nitrogen AM-350 plate in Table 2 did not completely transform to martensite on cooling from the braze temperature Sub-zero cooling for 3 hours at $-100 F$ was necessary to complete the transformation As in the case of AM-355, tempering for 3 hours at $1000 \mathrm{~F}$ had italatively little effect on dimensions measured at room temperature

It may be noted that average dimensional change values for the large (5/8-inch $\times 15$-inch $\times 24-1 n c h$ ) low-carbon, low-nitrogen AM-350 plate are reported in Table 2 in terms of both hole distance and overall dimensions There was very good agreement between the two methods of measuring dimensional change

Cumulative shrinkage from repeated braze cycles was more severe in low-carbon, low-nitrogen AM-350 than in AM-355 This may be seen by comparing dimensional change values for the same thermal treatment condition, braze plus subcool, for successive cycles

As in the case of AM-355, the AM-350 plate showed some anisotropy in that the longitudinal (length) direction was always smaller than the transverse (width) direction for the same thermal condition

The M2 tool-steel plates in Table 2 were not nearly as undersize, only about $1 \mathrm{mll}$ per 1 nch, as AM-355 or $\mathbb{A M}-350$ after the braze Subsequent sub-cooling and tempering both led to additional transformation of austenite causing an expansion and returned the plate dimensions close to those of the as-received condition in measurements at room temperature

Cumulative shrinkage in $\mathrm{M} 2$ from cycle to cycle was very low or nonexistent, (Table 2 and Figure 7)

Anisotropy effects were low and amounted to about 05 mil per inch dimensional difference between the longitudinal and transverse directions in the large $(5 / 8$-1nch $\times 24$-1nch $\times 24$-1nch) crossrolled plate of $\mathrm{M} 2$ with the longitudinal direction tending to be the smaller of the two dimensions

b AM-355 Machined Fixture Plates (Process $M$ )-The dimensional changes observed on 
the top and bottom plates of AM-355 brazing fixtures originally designed for AM-350 development grids are listed in Table 3 and Figure 7 There was a substantial undersize condition after the braze, amouning to 3 to 6 mils per inch, indicating incomplete transformation of austenite to martensite The sub-cool completed the transformation, causing expansion Tempering for 3 hours at $1000 \mathrm{~F}$ had relatively little effect, but it did tend to shrink the plates slightly due to contraction of the martensite latice The dimensional behavior of Heat 27205 as fixture plates for the reflector grid was very similar to that of the plate specimen of the same heat shown in Table 2 and Figure 7 for the first braze plus sub-cool

The different fixtures and heats of AM-355 material in Table 3 did not respond dimensionally in the same way to thermal treatment The cumulative shrinkage effect was noted to be less marked in the fixture plates for the seed grid (Heat 26818) than in those for the 218-cell blanket array (Heat 27268)

c Dilatometer Test Specumens (Pro. cess $M$ )-The 0 250-inch-diameter $\times 2000$-1nchlong dilatometer test specimens were measured with a micrometer having a vernier scale to the nearest $00001 \mathrm{inch}(01 \mathrm{mil})$ before and after each heating to the braze temperature (2070F) which involved constant heating and cooling rates, and before and after each sub-zero cool ( 3 hours at - 100F) The dimensional changes at 70F in the 2-inch direction from the as-received condition are listed for several specimens in Table 4, and include specimens taken in the longitudinal and transverse directions Comparison of these dimensional changes with those determined on plate specimens of the same heats of AM-355, AM-350, and M2 tool steel subjected to Process $\mathrm{M}$ heating and cooling rates in the production vacuum furnace show close agreement Therefore, the metallurgical reactions affecting dimensions during the dilatometer tests closely approximated those in the actual Process $M$ cycle

d Dimensional Restoration Thermal Treat ment (Process $M$ )-Experimental thermal treatments were applied to $\overline{A M}-355, \bar{A} \mathrm{M}-350$, and $\mathrm{M} 2$ tool steel bars and plates in an attempt to produce a response (dimensional expansion from the prior condition) which would have merit in offsething the cumulative shrinkage experienced from previous repeated braze cycles As mentioned earlier, the low-carbon, low-nitrogen $\AA$ M-350 material tended to experience the most severe cumulative shrinkage, while AM-355 material was intermediate and M2 material exhibited little or no cumulative shrinkage at room temperature measurements

The thermal treatments were applied in the production vacuum furnace and are described in
Table 5, using terminology which is common for AM-350 and AM-355 but not necessarily applicable to M2 These treatments included an equalizing treatment ( 3 hours at 1400F), an overtemper ( 3 hours at 1100F), a trigger anneal (1 hour at $1710 \mathrm{~F}$ ), and a solution treatment ( 1 hour at $1900 \mathrm{~F}$ ) In the case of AM-350 and AM-355, application of the $1400 F$ equalizing treatment or the $1710 \mathrm{~F}$ trigger anneal, after the braze plus sub-cool, raises the alloy into the austenite temperature region, precipitates chromium carbides, and ensures that the $M_{s}$ temperature is raised well above room temperature For M2 tool steel, the 3 hours at $1400 \mathrm{~F}$ treatment is below the austenite region and essentrally amounts to an overtempering treatment If applied, the 1 hour at 1710 freatment would be in the low end of the austenite region for M2 Combined with slow cooling it would be considered to be an annealing treatment, although the temperature is slightly above the 1600 to $1650 \mathrm{~F}$ annealing range commonly used for $\mathrm{M} 2$

The 1 hour solution treatment at $1900 \mathrm{~F}$ dissolves all carbides in AM-350 and AM-355 and lowers the $M_{\text {s }}$ temperature If applied to $M 2$ tool steel, it would be in the austenite region above the 1600 to $1650 \mathrm{~F}$ annealing range, but below the hardening range of 2150 to $2275 \mathrm{~F}$ recommended for $\mathrm{M} 2$

The metallurgical basis of the experimental thermal treatments (with sub-zero cools) for dimensional restoration of AM-350 and AM-355 was to investigate the possibility of producing an expansion from the prior condition by decreasing the amount of retained austenite, increasing the amount of martensite, and for the 1900F solution treatment retaining all avalable carbon in solution in the martensite For M2 tool steel, overtempering ( 3 hours at 1400F) followed by sub-zero cooling was investigated because this should tend to reduce the amount of retaned austenite

The last thermal treatment which each material received before the sequence of dimensional restoration experiments was performed (prior condition) is presented in Table 5 For AM-355, a $1710 \mathrm{~F}$ trigger anneal plus sub-cool was most effective (produced the greatest expansion from the prior condition), while a $1400 \mathrm{~F}$ equalizing treatment plus sub-cool was also effective This is illustrated in Table 6 using data from Table 5 For lowcarbon AM-350 plate (Heat 7C601), the trigger anneal plus sub-cool also produced the greatest expansion from the prior condition, but the magnitude of the response was insufficient to be satisfactory The $1900 \mathrm{~F}$ solution treatment plus sub-cool was not beneficial for $\overline{A M}-355$ or AM-350 In the case of M2 tool steel (Heat 27433), the 3 hours at $1400 \mathrm{~F}$ treatment plus sub-cool produced an expansion which had merit for dimensional restoration purposes No other thermal treatments were investıgated for M2 
e Metallography (Process M)-No dimensional restoration thermal treatment described in the previous section was satisfactory for lowcarbon AM-350 Furthermore, the trigger anneal plus sub-cool or the equalize plus sub-cool treatments which had merit for AM-355 did not prevent the resumption of cumulative shrinkage in AM-355 during the next braze cycle (This may be seen in Tables 5 and 6 by comparing the dimensional change values in the column Next Braze Cycle on the right side of the table with those for the Prior Condition ) The dimensional restoration treatments applied in Tables 5 and 6 depend upon manipulation of the relative amounts of martensite and austenite to cause a net expansion, their benefit is only temporary, and they would have to be reapplied after every few braze cycles as cumulative shrinkage continued

The change in morphology of the delta ferrite phase was examined as a result of repeated brazes to assess its possible role in cumulative shrinkage of the length and width dimensions and cumulative expansion of the thickness direction of plate Figure 8 shows a longitudinal section of AM-355 plate (Heat 27205), containing delta ferrite stringers (with carbide precipitate) in the as-received condition After the fourth braze, the delta ferrite stringers in Figure 9 have become more discontinuous, breaking up into short segments in the length and width dimensions of the plate Also, they have become thicker in the thickness direction of the plate Figure 10 shows delta ferrite phase in a transverse section of extra low-carbon AM-350 bar in the as-received condition versus the condition after the third braze The three brazes tended to make the delta ferrite phase more discontinuous, and more equiaxed (thicker) By contrast, the M2 tool steel (Heat 27433) shown in Figure 11, which did not contain or develop delta fernte, also did not exhıbıt marked cumulative shrinkage effects Therefore, it seemed possible that if the delta ferrite phase morphology could be stabilized (without the development of large additional amounts) prior to machining fixture plates from AM-350 or AM-355, cumulative shrinkage in the length and width dimensions and cumulative expansion in the thickness dimension of those alloys might be minimized after repeated braze cycles

f Dimensional Stabiluzation Thermal Treatment Experiment (Process $M$ )-An experimental high-temperature stabilization treatment ( 6 hours at $2150 \mathrm{~F}$ in vacuum followed by a sub-zero cool) was applied to dilatometer test specimens of lowcarbon, low-nitrogen AM-350 plate (Heat 7C601) and AM-355 plate (Heat 27205) of known cumulative shrinkage characteristics The purpose was to stabilize or spheroudize the morphology of the delta ferrite phase prior to repeated heating cycles to the braze temperature (with sub-zero cools), which would permit evaluation of dimensional change and cumulative shrinkage effects in the length (longitudinal) and width (transverse) directions of plate However, this stabilizatuon treatment did not prove to be effective in the preliminary evaluation, as the results in Table 7 show for the transverse direction Application of the first braze cycle resulted in shrinkage from the starting condition, and application of the second cycle resulted in further shrinkage This shrinkage occurred in spite of the fact that the delta ferrite stringers were broken up by the prior $2150 \mathrm{~F}$ treatment, e $\mathrm{g}$, compare Figure 12 with Figure 8 for AM-355 and see Figure 13 for low-carbon, low-nitrogen AM-350 Thus the major change in the morphology of the delta ferrite phase towards an equiaxed form per se did not appear to be the controlling factor in cumulatıve shrinkage

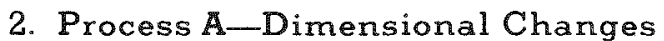

a Bar and Plate Specimens (Process A)-The Process A braze was applied to bar and plate specimens of $\mathrm{N}_{1} \mathrm{CrFe}$ Alloy 600 , and the results of dimensional change tests are given in Table 8

The $\mathrm{N}_{1} \mathrm{CrFe}$ Alloy 600 bars and plates were in the annealed condition as-received Application of five Process A brazes (with cools to room temperature) resulted in negligible dimensional change, all measured changes were in the range of -03 to $+02 \mathrm{mll}$ per inch No cumulative shrinkage effect was observed

Anisotropy effects were very minor in the plate (Heat NX0895), the maximum difference between the length and width dimensions being only $03 \mathrm{mil}$ per inch, with the longitudinal or rolling direction tending to remain smaller than the transverse (width) dimension However, the longitudinal or rolling direction dimension of the bar (Heat NX1675) tended to behave in the opposite manner and remain slightly larger as a result of braze cycles

Dimensional change, cumulative shrinkage, and anisotropy were not problems with $\mathrm{N}_{1} \mathrm{CrFe}$ Alloy specimens

b Machined Fixture Plates (Process A)-No Process $A, N_{1} C r F e$ Alloy 600 machined fixture plates were measured for dimensional change as a function of repeated braze cycles in this study because little brazing/fabrication work was conducted with Process $\bar{A}$ in this period

c Dilatometer Test Specimens (Pro cess $A$ )-Measurements on the $0250-1 n c h-$ diameter $\times 2000$-inch-long dilatometer test specimens from $\mathrm{N}_{1} \mathrm{CrFe} A$ lloy 600 plate 
(Heat 0895) were made before and after each heating cycle Compared to the as-received dimension in the 2-inch direction, dimensional change varied from 00 to $-01 \mathrm{ml}$ per inch for the longitudinal specimen given three heating cycles, and remained at about $-01 \mathrm{mil}$ per inch for the transverse specimen given four heating cycles These minor changes were of the same magnitude as in the bar and plate specimens in Table 8 and much less than those for the Process $M$ specimens of Table 4

d Metallography (Process A)-The only significant microstructural change occurring in $\mathrm{N}_{1} \mathrm{CrFe}$ Alloy 600 bar and plate as a result of repeated Process $\bar{A}$ braze cycles was grain growth $F_{1 g}$ ure 14 shows an increase in grain size in the plate (Heat NX0895) after three brazes from ASTM 7 to ASTM 3 After five brazes it was ASTM 1 This contrasts with the extremely fine grain size of M2 tool steel shown in Figure 11 which was maintained through four Process M brazes $\mathrm{N}_{1} \mathrm{CrFe}$ Alloy 600 , unlike the Process $\mathrm{M}$ brazing fixture materials, did not go through a phase transformation on heating and cooling which would tend to refine the gram size In addition, the carbide dispersion in M2 tool steel retarded grain growth in the austenitic region However, the grain growth occurring in $\mathrm{N}_{1} \mathrm{CrFe}$ Alloy 600 would not be detrimental to its use as a brazing fixture material

\section{Flatness Changes Due to Brazing Cycles}

The flatness of bar and plate specimens of various fixture materials and AM-355 machined fixture plates were determined before and after thermal treatments Measurements were made to the nearest $00001 \mathrm{inch}(01 \mathrm{ml})$ after leveling each bar or plate according to a standarized procedure The flatness of bar specimens 9 inches long was measured at the same three locations each time (at the center and at $1 / 2$ inch from each end) The 9-1nch $\times 9$-inch plates were measured at nine locations (at the center and at eight locations equally spaced around the plate within $1 / 2$ inch of the edge) The larger plates and the machined fixture plates were measured at from 9 to 21 locations across the plate each time These locations were at fiducial marks or at intersections of fiducial marks The results are reported here as flatness within the total indicated range for several thermal treatments

\section{Process M-Flatness Changes}

a Bar and Plate Specumens (Process $M$ )-The results of the flatness determinations on bar and plate specimens to which the Process M braze was apphed are given in Table 9 Warpage, especially of the larger plates, becomes progressively worse with increasing number of brazing cycles

b AM-355 Machined Fixture Plates (Process $M$ )-The flatness results on the top and bottom plates of AM-355 brazing fixtures are reported in Table 10 The out-of-flatness increased signif1cantly as a result of the first braze cycle

\section{Process A-Flatness Changes}

a Bar and Plate Specimens (Process A)-The flatness measurements on $\mathrm{NiCrFe}$ Alloy 600 bar and plate are given in Table 11 The warpage of $\mathrm{N}_{1} \mathrm{CrFe}$ Alloy 600 was so small as to be negligible This contrasts with the results for the Process $M$ specimens AM-355, AM-350, and M2 tool steel given in Table 9 All of the latter materials go through phase transformations on heating and cooling, while $\mathrm{N} \mathrm{CrFe}$ Alloy 600 does not

\section{DISCUSSION}

\section{A. Process A}

For Process $\mathbb{A}$ the thermal expansion on heating to the brazing temperature and cooling to room temperature of $\mathrm{N}_{1} \mathrm{Cr}_{\mathrm{r}} \mathrm{Fe}$ Alloy 600 matches well with that of austenitic AM-350 sheet as shown in Figure 5 Dimensional design of the stable austenitic $\mathrm{N} 1 \mathrm{CrFe}$ Alloy 600 fixture plates is not a problem as long as the AM-350 sheet, originally in the austenitic condition, does not begin to transform to marlensite and expand on cooling to room temperature after the braze $\mathrm{N}_{1} \mathrm{CrFe}$ Alloy $600 \mathrm{f}_{1 \mathrm{x}}-$ ture material exhibits negligible anisotropy, dimensional change, cumulative shrinkage, and flatness change effects in Process A

\section{B. Process $M$}

Comparison of the results of dilatometer tests on candidate brazing fixture materials AM-355, lowcarbon, low-nitrogen (0 053 percent C, 0064 percent N) Type II AM-350 plate, and M2 tool steel with Types I, II, and III AM-350 sheet show that none of the fixture materials precisely match the thermal expansion and contraction characteristics of AM-350 sheet for the braze portion of the cycle (from room temperature to the braze temperature and back to room temperature) where the grid will be held by the fixture Indeed, each type of AM-350 sheet has somewhat different thermal expansion and contraction characteristics, depending on carbon and nitrogen contents These AM-350 sheet differences are relatively small 100007 inch per inch or $07 \mathrm{mll}$ per inch maximum) at the braze temperature, but are indicated 
to be as much as 28 mils per inch on cooling to room temperature The latter difference is due to a variation in the $M_{s}$ temperature (between about $250 \mathrm{~F}$ and 100F) and the resultant difference in degree of transformation and expansion occurring before room temperature is reached It should be pointed out, however, that the lower carbon and nitrogen AM-350 materials, Types II and III, show a dimensional difference of only $09 \mathrm{mil}$ per 1 nch at room temperature

The heats of candidate fixture materials AM-355, Type II AM-350, and M2 tool steel tested match sufficiently well the thermal expansion of the various types of AM-350 sheet, so that all of the candidate fixture materials could be used (with appropriate, small allowances in fixture dimensional design) for the heating portion of the braze cycle However, the situation on cooling from the braze temperature to room temperature is more difficult from a fixture dimensional design viewpoint because of the abrupt transformation of austenite to martensite which starts between $250 \mathrm{~F}$ and 100F in AM-350 sheet, depending on carbon and nitrogen content Although there is good dimensional match in Process $\mathrm{M}$ between $\mathrm{AM}-355$ or low-carbon, low-nitrogen AM-350 fixture plates and AM-350 sheet from the brazing temperature down to the $M_{s}$ temperature, this mismatch of $M_{s}$ temperatures and variability in degree of transformation and resultant expansion present problems in fixture design and probably grid dimensions Furthermore, in production brazing even relatively small temperature differences between various parts of the grid and fixture could result in transient and uncontrolled dimensional differences of the order of 4 to 5 mils per inch in. the temperature range from about $250 \mathrm{~F}$ to room temperature (This transformation mismatch problem could possibly be eliminated by hot lift off of the AM-355 or Type II AM-350 fixture from the grid while holding the temperature above about 250F, but this method and its effect on dimensions of sample material were not investigated)

M2 tool steel exhibits good dimensional match with AM-350 sheet on cooling from the brazing temperature down to the transformation temperature of $\mathrm{M} 2$ at about $750 \mathrm{~F}$ where austenite starts to transform to bainite At 750F, the M2 expansion due to transformation begins to pull the grid (by exerting a tension force) towards dimensions characteristic of completely transformed AM-350 sheet At room temperature, the M2 and the completely transformed AM-350 sheet (tested separately by dilatometry) exhibit the same dimensions after the brazing cycle Between about $600 \mathrm{~F}$ and the $\mathrm{M}_{\mathrm{s}}$ temperature of the $\mathrm{AM}-350$ sheet, there is a mismatch of 3 to 5 mils per inch between the transformed $\mathrm{M} 2$ and the untransformed AM-350 sheet This mismatch may cause only elastic distortion of the AM-350 grid on an actual M2 fixture However, this can be determined only by brazing tests of full-size grids on fixtures

Anisotropy was not a severe problem in AM-355, low-carbon, low-nitrogen AM-350, and M2 tool steel fixture plates, being minimized by procuring cross-rolled material given equal percent reductions in the length and width directions

Dimensional change (shrinkage) in the length and width directions of plate as the result of one Process M braze is counteracted in AM-355 and AM-350 fixture plates by applying a sub-zero cool ( 3 hours at $-100 F$ ) to complete the transformation and cause an expansion before the fixture is used for the next braze $\mathrm{M} 2$ tool steel is sub-zero cooled and tempered for 3 hours at l000F for the same purpose to return dimensions at $70 \mathrm{~F}$

Cumulative shrinkage as a result of repeated Process $M$ brazing cycles occurs in the length and width dimensions of $A M-355$ plate and, to a greater degree, in low-carbon, low-nitrogen AM-350 plate Application of a trigger anneal (1 hour at 1710F) with sub-zero cool or an equalizing treatment ( 3 hours at $1400 \mathrm{~F}$ ) with sub-zero cool after two or so brazing cycles is effective in restoring tempoiarly the dimensions of AM-355 plate to those of the original condition However, cumulative shrinkage resumes with application of the next braze cycle For low-carbon, low-nitrogen AM-350 plate there is no effective dimensional restoration thermal treatment The M2 tool steel exhibits little or no cumulative shrinkage If necessary, an overtemper ( 3 hours at $1400 \mathrm{~F}$ ) followed by a sub-zero cool may be applied to offset shrinkage at $70 \mathrm{~F}$

A high-temperature thermal treatment $(6$ hours at $2150 \mathrm{~F}$ ) did not eliminate cumulative shrinkage in AM-355 and low-carbon, low-nitrogen AM-350 material through stabilization of the morphology of the delta ferrite phase $\bar{A}$ stabilization treatment, if proved effective, might be applied to $A M-355$ and AM-350 plates before machining of fixtures

Flatness changes in Process $M$ fixture materials were characteristized as a function of braze cycles Results indicate that AM-355, AM-350, and M2 fixture plates may require flattening after every two or more brazing cycles

\section{CONCLUSIONS}

\section{A. Candidate Brazing Fixture Material Characteristics}

1 The most compatible thermal expansion characteristics were observed between Pro$\operatorname{cess} A, A M-350$ (austenitic) and $\mathrm{N}_{1} \mathrm{CrFe}$ Alloy 600 brazing fixture material Also, dimensional change, cumulative shrinkage, and flatness change were minimal with the 
brazing fixture material of Alloy 600 (which did not undergo phase transformations). Thus, other things being equal, the selection of Process $\bar{A}$ brazing and heat treating cycle, using $\mathrm{NiCrFe}$ Alloy 600 brazing fixtures, is preferable for fabrication of fuel rod support grids made from AM-350 stainless steel material. This combination will (1) minimize grid distortion and the potential for braze joint lissuring due to thermal expansion mismatch stability, and (2) provide the longest useful fixture life because of its excellent dimensional stability with repeated usage.

2. AM-355 would be the preferred candidate brazing fixture material if Process $M$ were chosen as the braze/heat treatment process for fuel rod support grids made from AM-350 stainless steel material. AM-355 provided good dimensional match with $A$ M-350 sheet in Process $M$ on heating and on cooling from the brazing temperature down to the $\mathrm{M}_{\mathrm{s}}$ temperature. Lifting the fixture from the grid at approximately $250 \mathrm{~F}$ while above the $\mathrm{M}_{\mathrm{s}}$ temperature and still austenitic is a possible practical way of overcoming possible mismatch between the grid and fixture during the austenitic-to-martensite phase transformation.

Shrinkage in the length and width directions as the result of one Process $\mathrm{M}$ braze was counteracted in $\bar{A} M-355$ fixture plates by applying sub-zero cool to complete the martensitic transformation and to cause an expansion before the material underwent the next braze cycle. Cumulative shrinkage was counteracted by application of a 1710F trigger anneal with sub-zero cool, or a $1400 \mathrm{~F}$ equalizing treatment with sub-zero cool, after two or more brazing cycles to restore, at least temporarily for the next braze, AM-355 plates to original dimensions. Flattening treatments would have to be investigated for application to AM-355 plates, which undergo phase transformations during the brazing cycle.

3. M2 had dimensions which were reproducible and very close to those of AM-350 sheet at the brazing temperature and at room temperature (for completely transformed, martensitic $\AA \mathrm{AM}-350$ ) after cooling from the brazing temperature. However, on cooling, the austenite transformed at a higher temperature in $\mathrm{M} 2$ than in $\mathrm{AM}-350$, resulting in a mismatch of 3 to 5 mils per inch between about $600 \mathrm{~F}$ and the $\mathrm{M}_{\mathrm{s}}$ temperature of the AM-350 sheet. Due to this relatively high temperature mismatch, M2 is considered an unacceptable fixture material candidate.

4. Low-carbon, low-nitrogen AM-350 plate is considered an unacceptable brazing fixture material because there is no effective thermal treatment to restore dimensions after brazing cycles to improve fixture lifetime.

5. Based on this study, it is concluded that a single-phase material is a better candidate for a fixture material since there is much evidence that the presence of a second phase is responsible for the cumulative shrinkage effect observed and thus a short fixture lifetime.

\section{B. Procedures for Development of Brazing Fixtures}

\section{Procurement of Materials}

a. Cross-rolled material should be procured for brazing fixtures plates to minimize anis otropy effects. Equal reductions should be applied in both directions during rolling.

b. The final direction of rolling, (longitudinal direction) should be identified on each plate.

c. Bar material should be procured for spacers and other fixture parts in a process condition as close as possible to the plate material.

2. Evaluation of Material Prior to Design and Machining of Fixtures

a. Samples should be taken from each material lot and tested in regard to check analyses for major alloying elements and impurities, metallographic examination in the longitudinal and transverse directions for grain size, microstructure phase distribution and directionality dependence, and dilatometry in three successive braze cycles.

b. If there are wide variations between sample locations, consider either procuring a new lot of material or reheat treatment of the lot.

3. Layout and Machining of Fixture Plates, Dimensional Measurements, and Thermal Treatments During Service

a. Fixture plates should be layed out and machined with the final rolling direction identified on the fixture so that subsequent dimensional measurements during service can determine if possible anisotropy parallel with and perpendicular to the rolling direction influences fixture lifetime. 
b Length and width dimensions at reference locations and flatness should be determined prior to and during braze cycle service Extent of dimensional change should be assessed to determine if a dimensional restoralion treatment should be applied

\section{Chemistry and Heat Treatment} Information on Materials Investigated (This information is presented in Table 12.)

\section{EXPERIENCE WITH PRO- CESS M DEVELOPMENT BRAZ- ING FIXTURE MATERIALS}

\section{A. Process M-M2 Tool Steel Braz- ing Fixture Mismatch with Grid}

Subsequent to the experimental investigation of candidate brazing fixture material characteristics, Process M brazing experience with M2 tool steel fixture plates in full-size grids confurmed the expected problems associated with dimensional mismatch as indicated by excessive cracking in the grid brazed joints This indicated that the expansion of M2 starting at $750 \mathrm{~F}$ on cooling and resulting in a mismatch of 3 to 5 mils per inch between about $600 \mathrm{~F}$ and the $\mathrm{M}_{\mathrm{s}}$ temperature of the $\mathrm{AM}-350$ sheet was in excess of that which the grid could withstand

\section{B. Process M-AM-355 Brazing Fix- ture Dimensional Stability}

Subsequent to the investigation of candidate brazıng fixture material characteristics, Process $M$ experience with AM-355 fixtures on full-size development grids was obtanned

Three sets of AM-355 brazing fixture plates were used to braze four grids of one type, two grids of a second type, and one grid of a third type using Process $M$ The braze plates were dimensionally inspected on the CORDAX measuring machine after each braze cycle The average dimensional changes from the original as-received plate $\mathrm{d}$ mension are listed in Table 13

The variable dimensional response of the three sets of AM-355 plates shown in Table 13, indicates that the response of $\mathrm{AM}-355$ to repeated hightemperature cycling is not easily predictable and would require more extensive investigation than carried out in the subject program

\section{Process $\mathrm{A}-\mathrm{NiCrFe}$ Alloy 600 Brazing Fixtures}

Process $\mathrm{A}$ and $\mathrm{NiCrFe}$ Alloy 600 brazing fixtures, which do not undergo phase transformation, were selected for use in production

\section{EXPERIENCE WITH LWBR PRODUCTION BRAZING FIX- TURES (Process A-NiCrFe Alloy 600 Brazing Fixtures)}

Based on extensive material property investigations of AM-350 reported in other WAPD technical memoranda, and in part due to the results of the information gained in this investigation, Process $\mathbb{A}$ was chosen as the braze/heat treatment procedure for the fabrication of LWBR fuel rod support grids Based on this investigation, $\mathrm{N}_{1} \mathrm{Cr} F$ e Alloy 600 was chosen as the brazing fixture material

LWBR grid production dimensional data for $\mathrm{N}_{1} \mathrm{CrFe}$ Alloy 600 brazing fixtures used to braze several fuel rod support grids are presented for two sets of fixture plates in Figures 15 through 18 The measurements on the top and bottom plates BA-2, S/N-01 in Figures 15 and 16 were obtained for 16 cons ecutive braze cycles, while those on the top and bottom plates BA-1, S/N-02 in Figures 17 and 18 were for 23 consecutive braze cycles The distances $A$ and $B$ were measured parallel with the final rolling direction of the plate, and $C$ and $D$ were perpendicular to the rolling direction These distances were measured between four sets of two insert holes each using an elevation gage with dial indicator on a granite surface table to the nearest 0001 inch $(1 \mathrm{mil})$ The fixture plates were flattened to within $10 \mathrm{mils}$ total indicated range after each braze cycle and before the $A, B, C$, and D dimensions were measured

A reference value of 15754 inches was used for the average of the $A+B$ dimensions, and a reference value of 17587 inches was used for the average of the $\mathrm{C}+\mathrm{D}$ dimensions Figures 15 through 18 indicate that frequently a variation of several mils was observed between average values of the dimensions from one braze cycle to another An indication of the long-range cumulative effect of the braze cycles on the dimensions of the fixture plates was obtained from the dimensional difference between the initial and last braze cycle measurements and is summarized in Table 14

The data shown in Table 14 indicate that the dimensional change (mils/inch) on the fixture plates was of about the same magnitude as that on Alloy 600 bar and plate specimens after five braze cycles (refer to Table 8) However, the data obtained on the blanket fixture plates were measured for a considerably greater number of cycles, 16 and 23 , and the predominant effect was an increase in dimensions, whereas the plate specimen in Table 8 showed a s mall (0 $3 \mathrm{mll} / \mathrm{inch}$ ) shrinkage in the rolling direction and no change perpendicular to the rolling direction The conclusions from this work were that the dimensions of the Alloy 600 fixture plates were stable, independent of their orientation relative to the final rolling direction 
Small differences existed between the temperatures used in the Process $A$ braze cycle in the experimental work and those used in production These differences were believed to be insignificant in regard to dimensional change The brazing cycle in production involved heating to $1830 \mathrm{~F}$ and holding to attain uniform temperature distribution This was followed by heating rapidly from $1830 \mathrm{~F}$ to the braze temperature of $2100 \mathrm{~F} \pm 20 \mathrm{~F}$ and holding for 5 to 15 minutes Cooling from $2100 \mathrm{~F}$ to $1710 \mathrm{~F}$ was performed in vacuum Then the furnace was back-filled with argon to a pressure of 11 inches of mercury resulting in rapid cooling to $250 \mathrm{~F}$ to prevent carbide precipitation The brazing f1xture plates were removed from the production grids in hot deionized water (200F) to ensure that no dimensional mismatches would occur due to partial martensitic transformation in the grids as they cooled to room temperature

\section{ACKNOWLEDGMENTS}

The experimental investigation of candidate brazing fixture material characteristics was performed in cooperation with $A$ W Klein, B R Gourley, C C Lowery, Jr, and J H Suldan Subsequent to this work, development preproduction experience with brazing fixture procedures and dimensional behavior was provided by L P Ebejer, R J Nilsen, and K D Richardson In- formation on production brazing fixture dimensional behavior was developed by L P Ebejer

\section{REFERENCES}

1 J Valentich, "Thermal Expansion Measurement", Instr. Control Systems, 42 (10) 91-94 (1969)

2 ASTM E228-66aT, "Tentative Method of Test for Linear Thermal Expansion of Rigid Solids with a Vitreous Silica Dilatometer," ASTM Standards, Part 31, July 1971, American Society for Testıng Materials, Philadelphia, Pa

3 Unpublished data obtained from B R Gourley, Bettrs Atomic Power Laboratory

4 "AM-350/AM-355 Precipitation Hardening Staunless Steels," Allegheny Ludlum Steel Corporation, Pittsburgh, $\mathrm{Pa}, 1963$

5 "Inconel Alloy 600," Third Edition, Huntıngton Alloy Products Division, The International Nickel Company, Inc, Huntington, West Vırginıa, 1969

6 Y S Touloukıan, Ed "Thermophysıcal Properties of High Temperature Solid Materials," Vol 2, PartII, Thermophysical Properties Research Center, Purdue University, The MacMillan Company, New York, 1967 


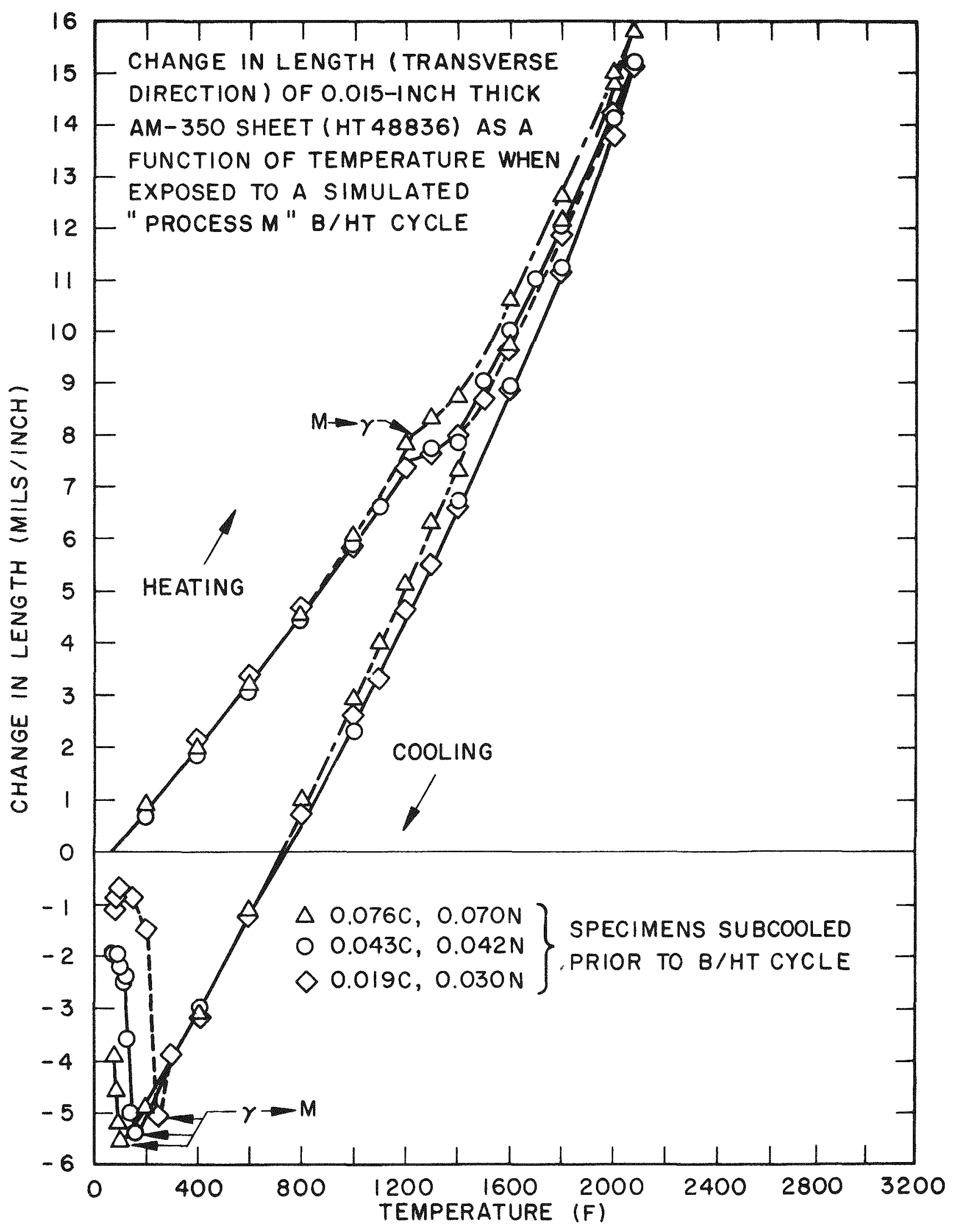

Figure 1. Dilatometer Tests for Process M Brazing on $\mathbf{A M - 3 5 0}$ Sheet Grid Material 


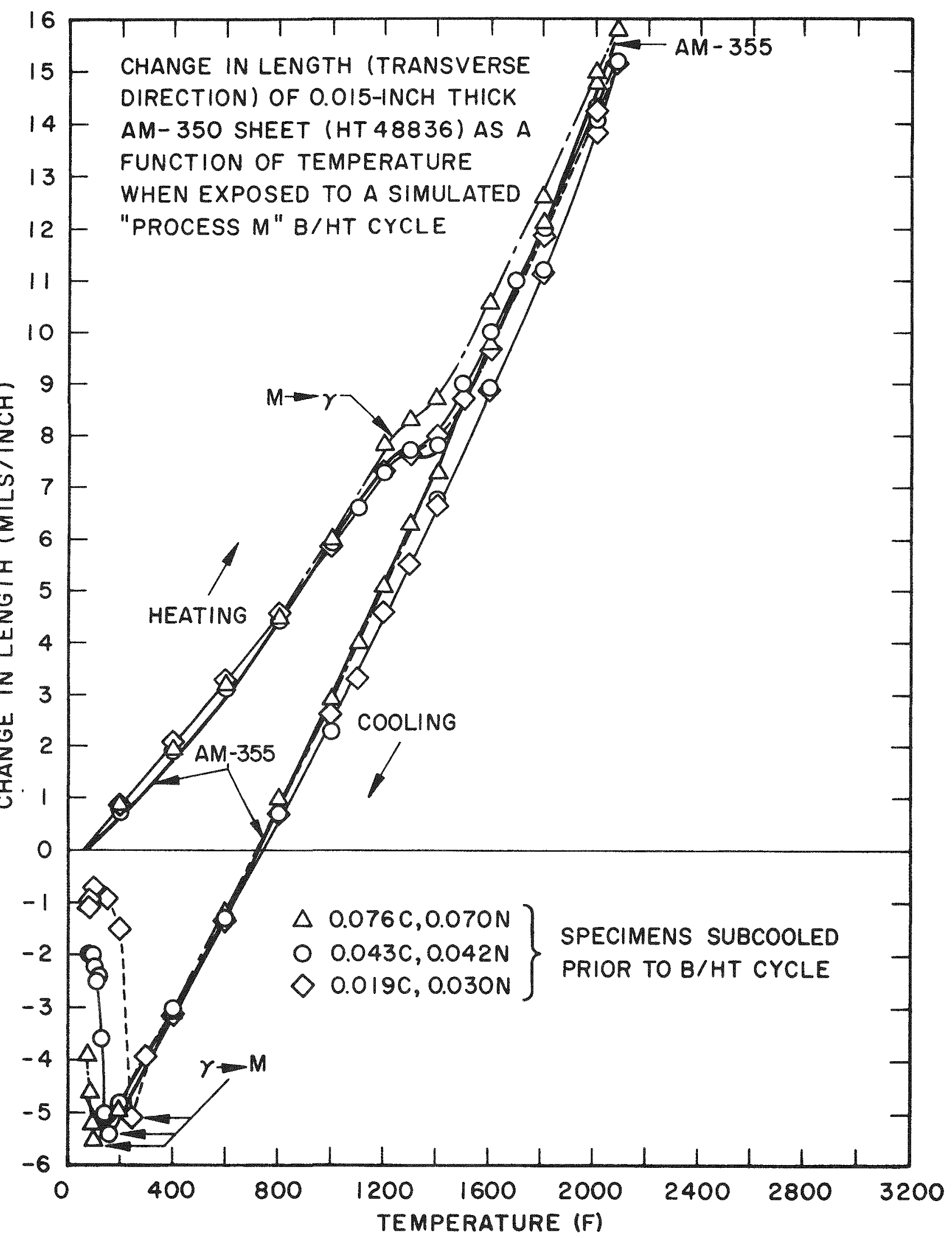

Figure 2. Dilatometer Tests for Process M Brazing on AM-355 Plate versus AM-350 Sheet 


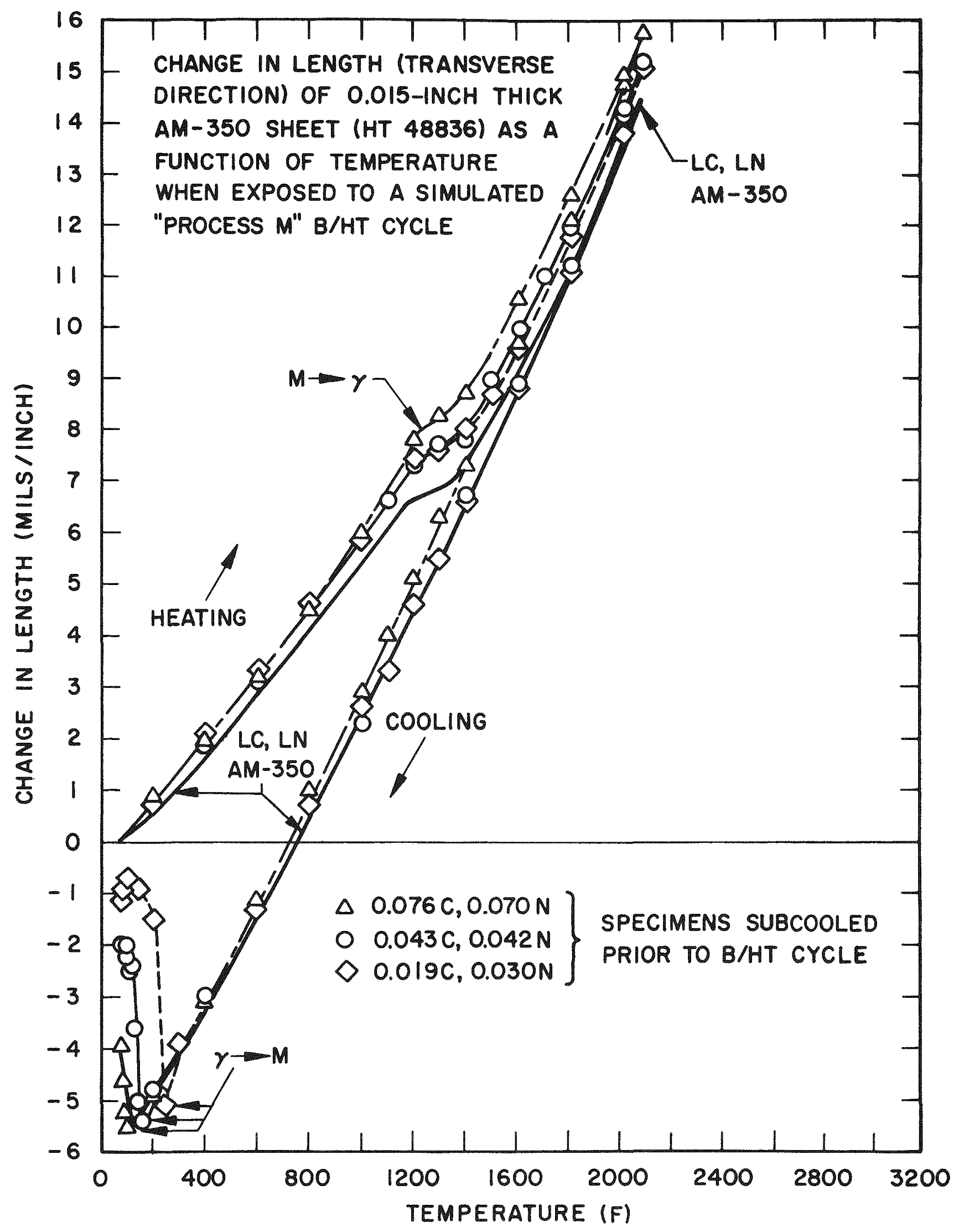

Figure 3. Dilatometer Tests for Process M Brazing on Low-Carbon, Low-Nitrogen AM-350 Plate versus AM-350 Sheet 


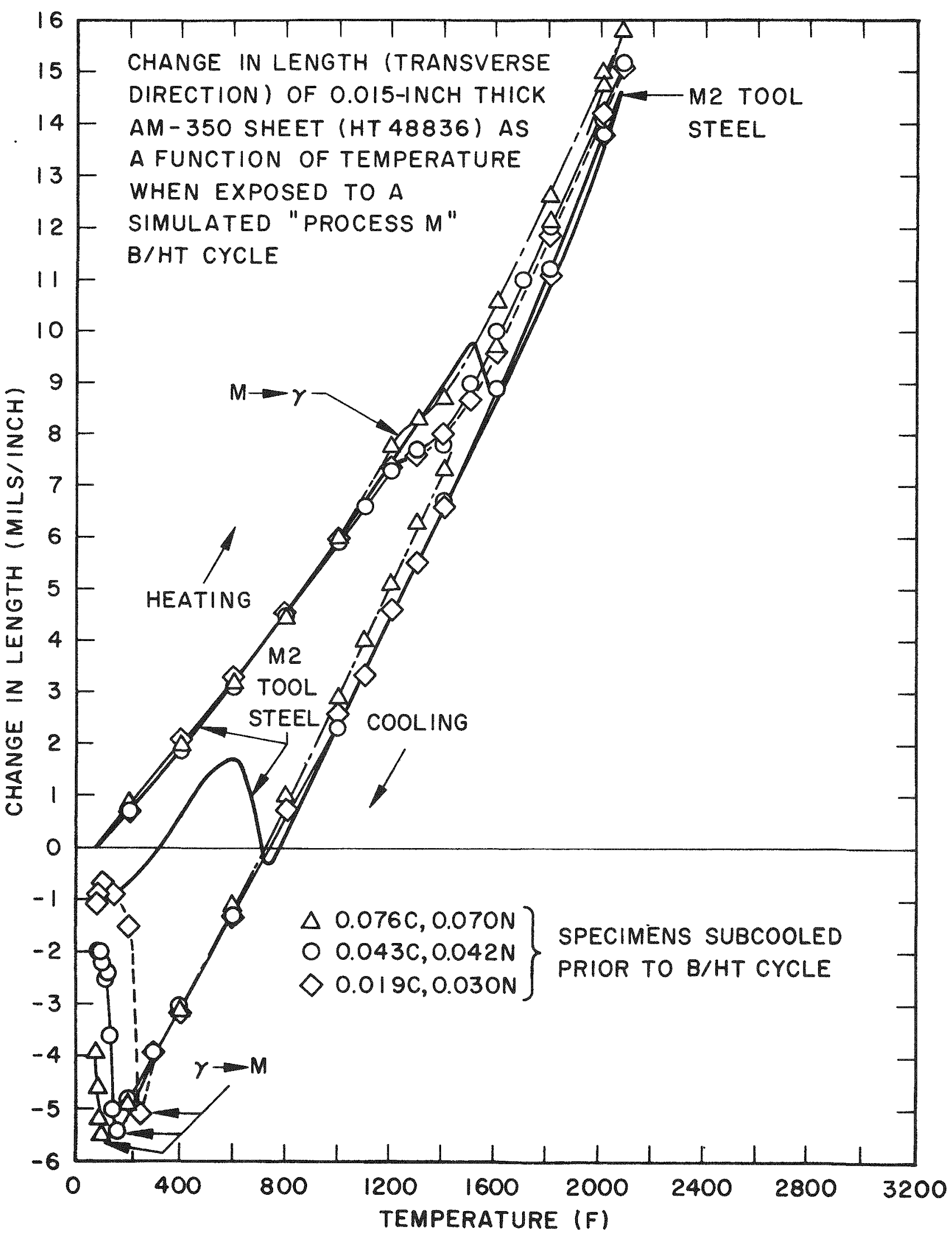

Figure 4. Dilatometer Tests for Process M Brazing on M2 Tool Steel Plate versus AM-350 Sheet 


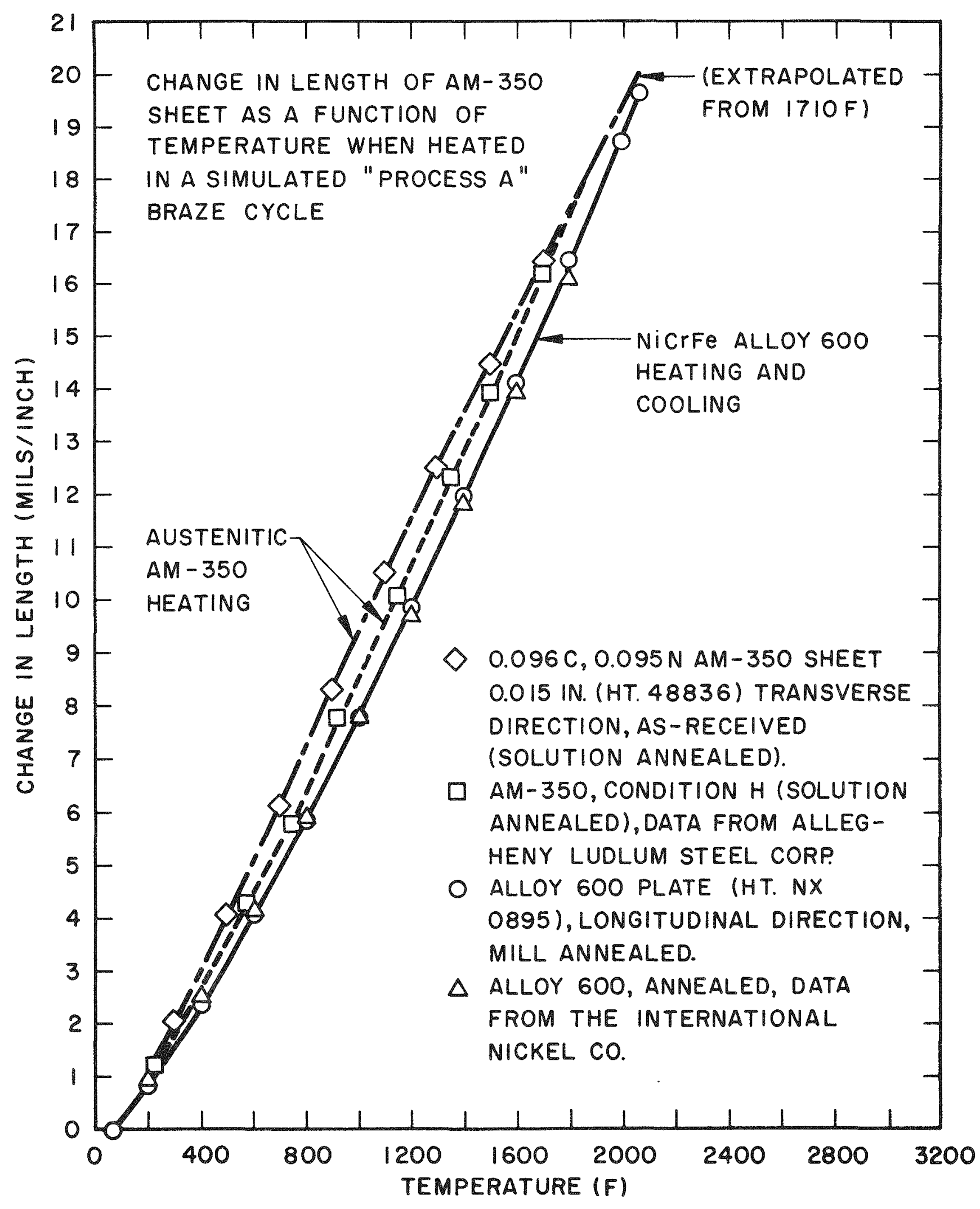

Figure 5. Dilatometer Tests for Process A Brazing on NiCrFe Alloy 600 Plate versus AM-350 Sheet 


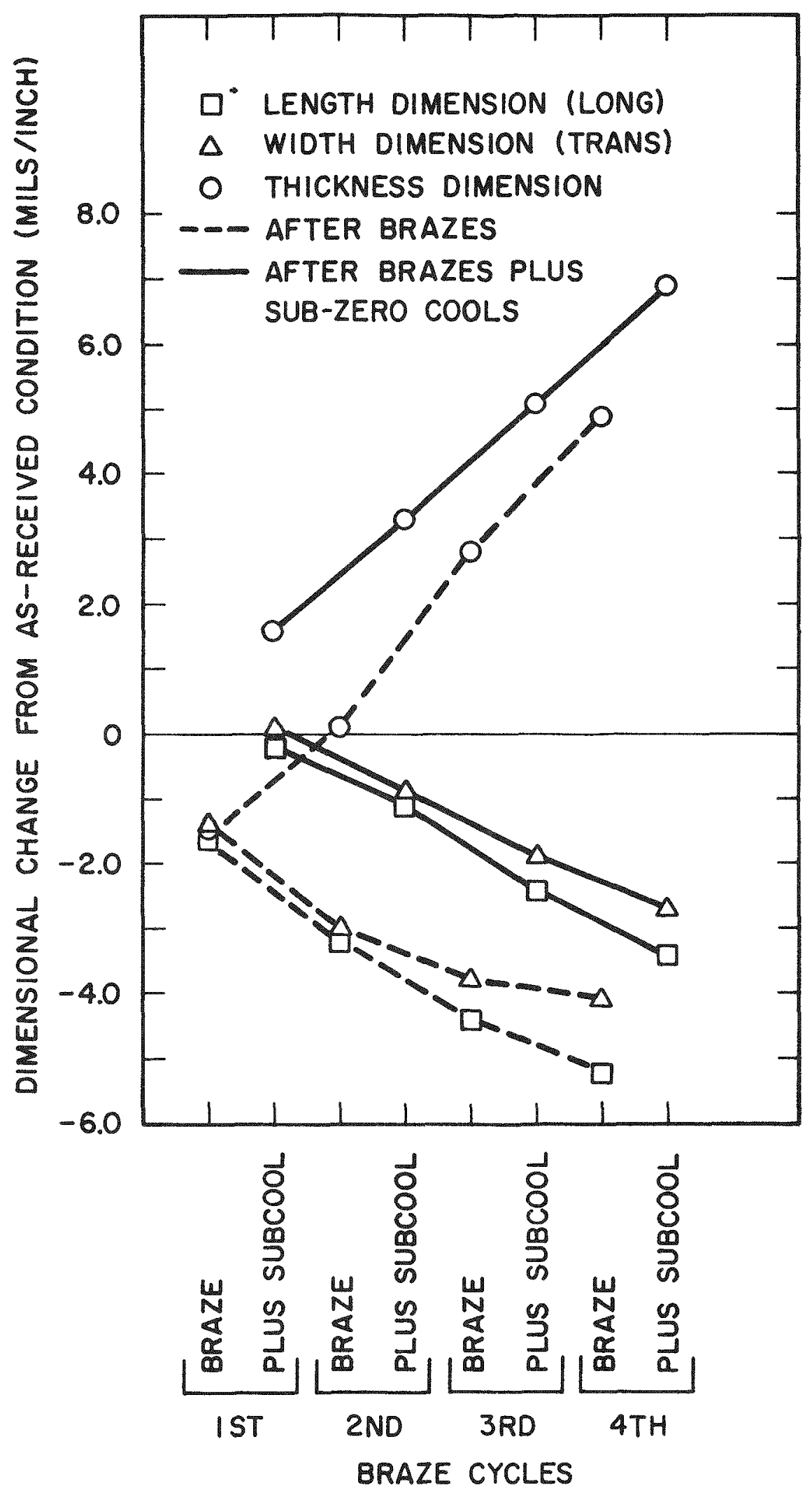

Figure 6. Process M-Dimensional Change Tests on Low-Carbon, Low-Nitrogen AM-350 Plate Fixture Material versus Braze Cycles 


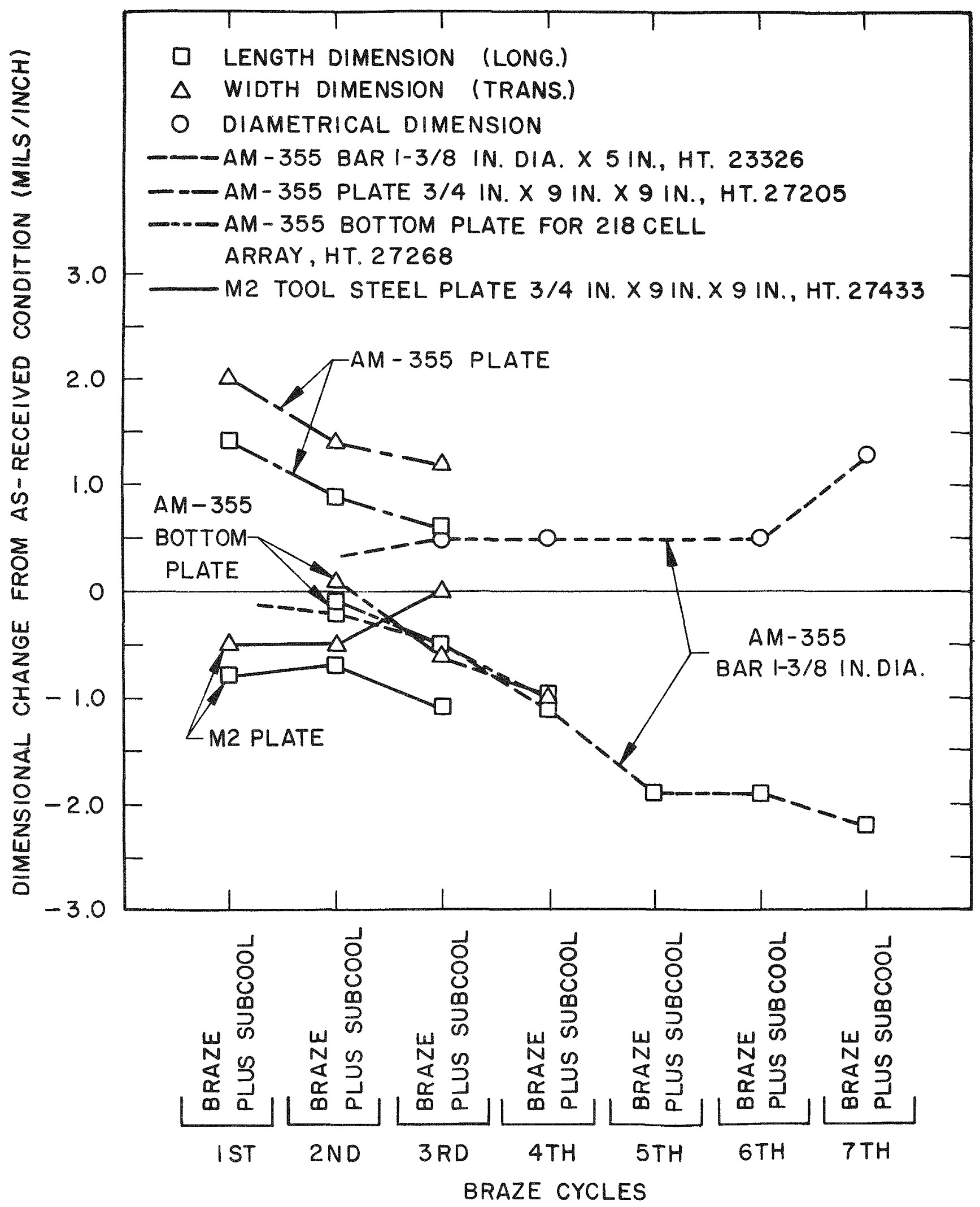

Figure 7. Process M-Dimensional Change Tests on AM-355 and M2 Tool Steel Fixture Materials versus Braze Cycles 


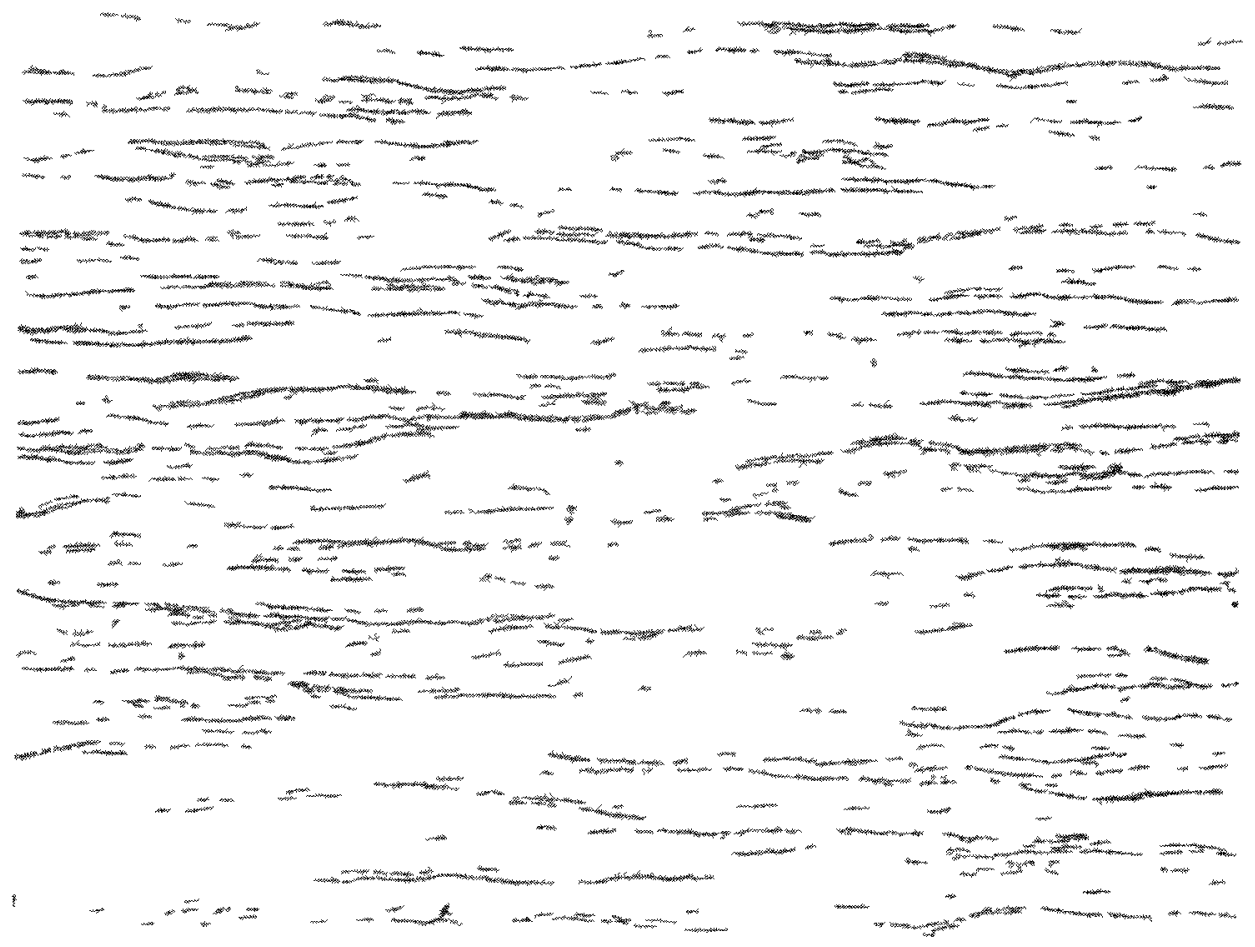

Mod. Vilella's Etch

Mag. 100x

At $1 / 4$ Thickness

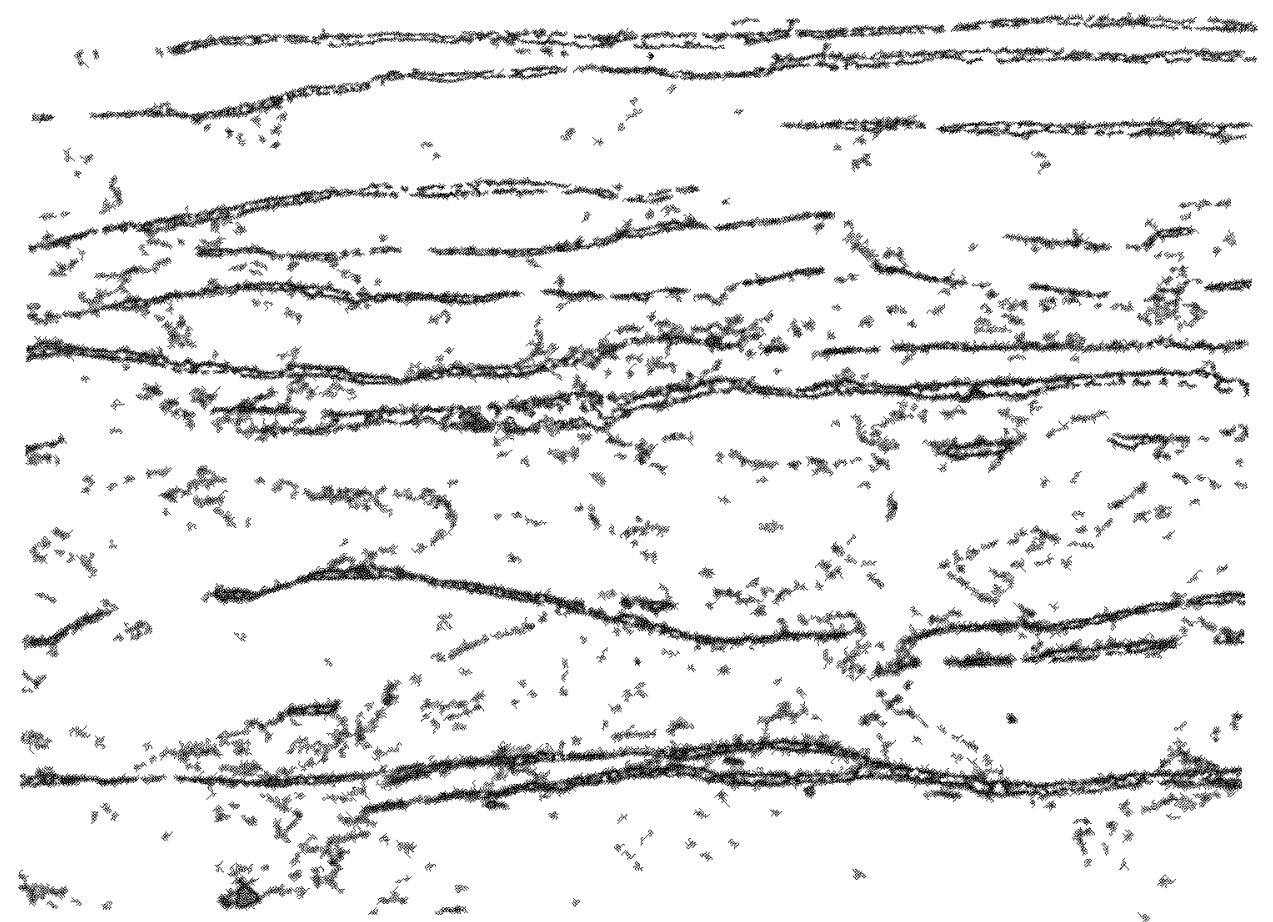

Mod. Villella's Etch

Mag. 500X

At 1/4 Thickness

Figure 8. Microstructure Showng Delta Ferrite Stringers in a Longitudinal Section of AM-355 Plate 3/4-Inch Thick (Heat 27205) in the As-Received Condition 


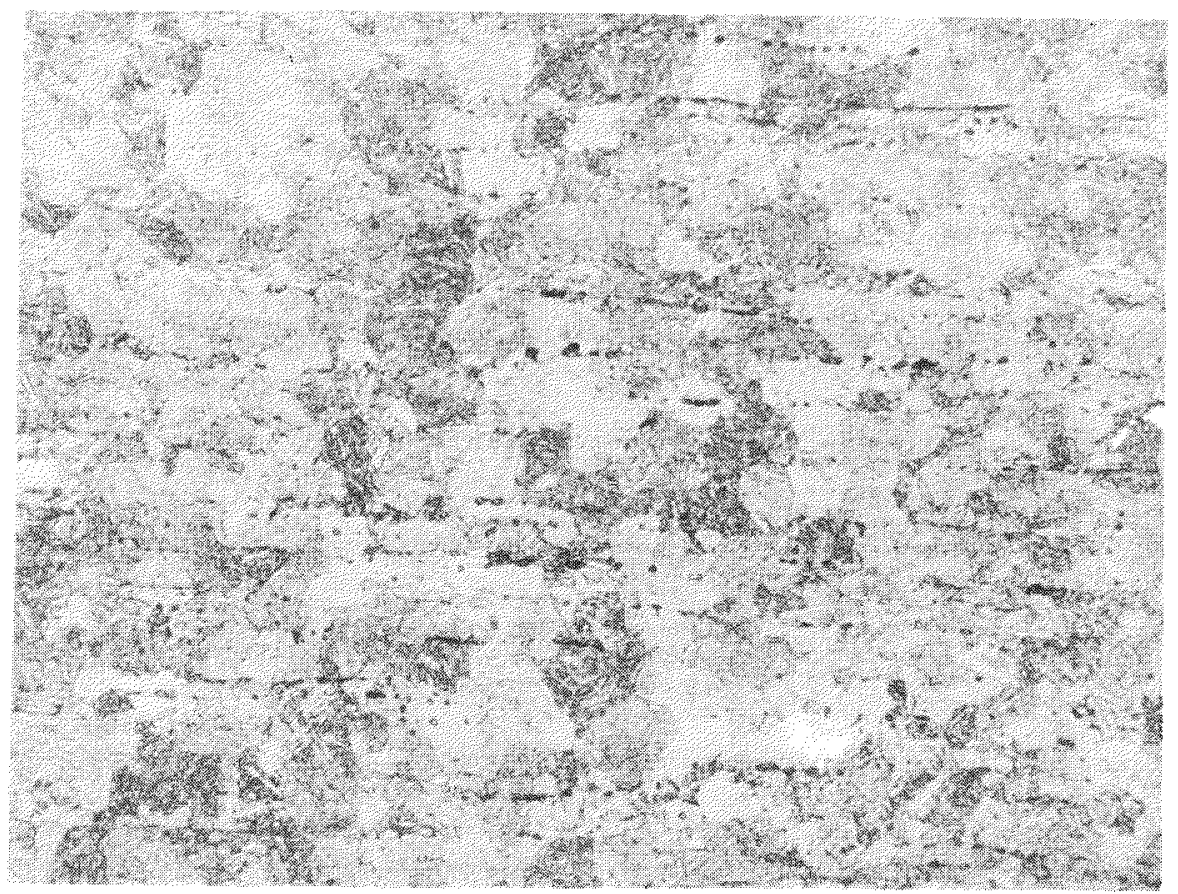

Mod. Kalling's Etch

Mag. 100X

At 1/4 Thickness

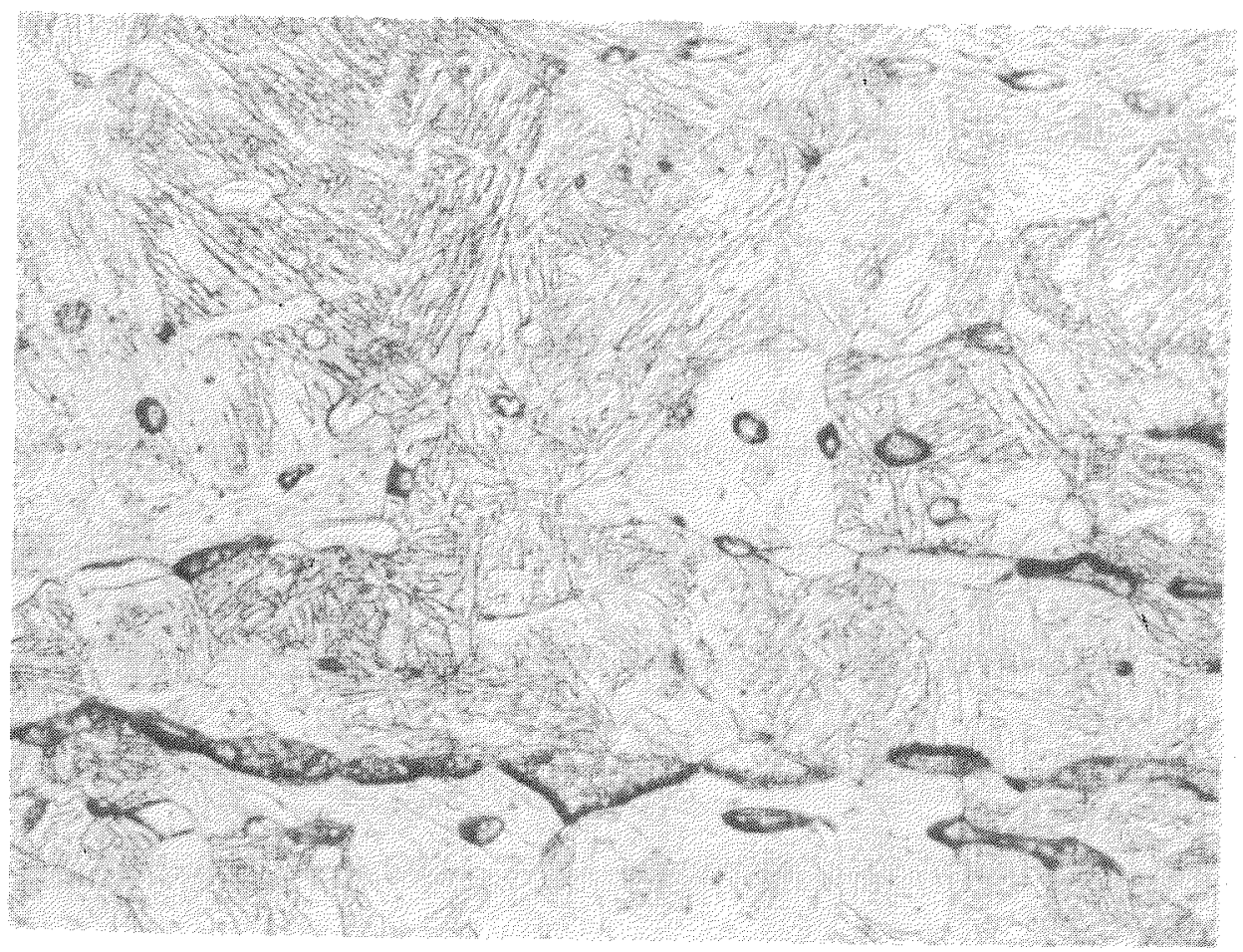

Mod. Kalling's Etch

Mag. 500X

At 1/4 Thickness

Figure 9. Microstructure Showing Remnants of Delta Ferrite Stringers in a Longitudinal Section of AM-355 Plate 3/4-Inch Thick (Heat 27205) After Fourth Process M Braze 


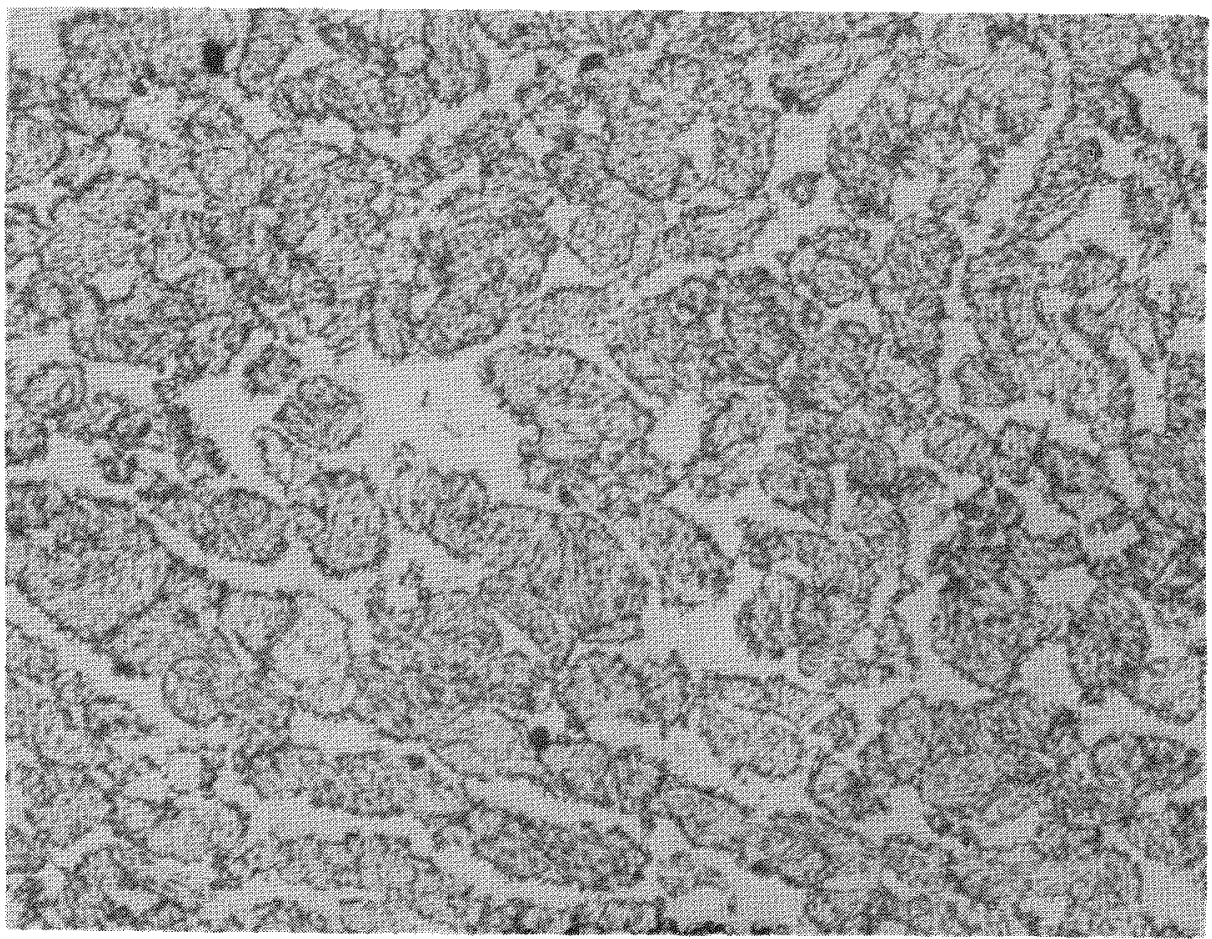

Mod Vilella's Etch

Mag. 500X

At 1/4 Thickness

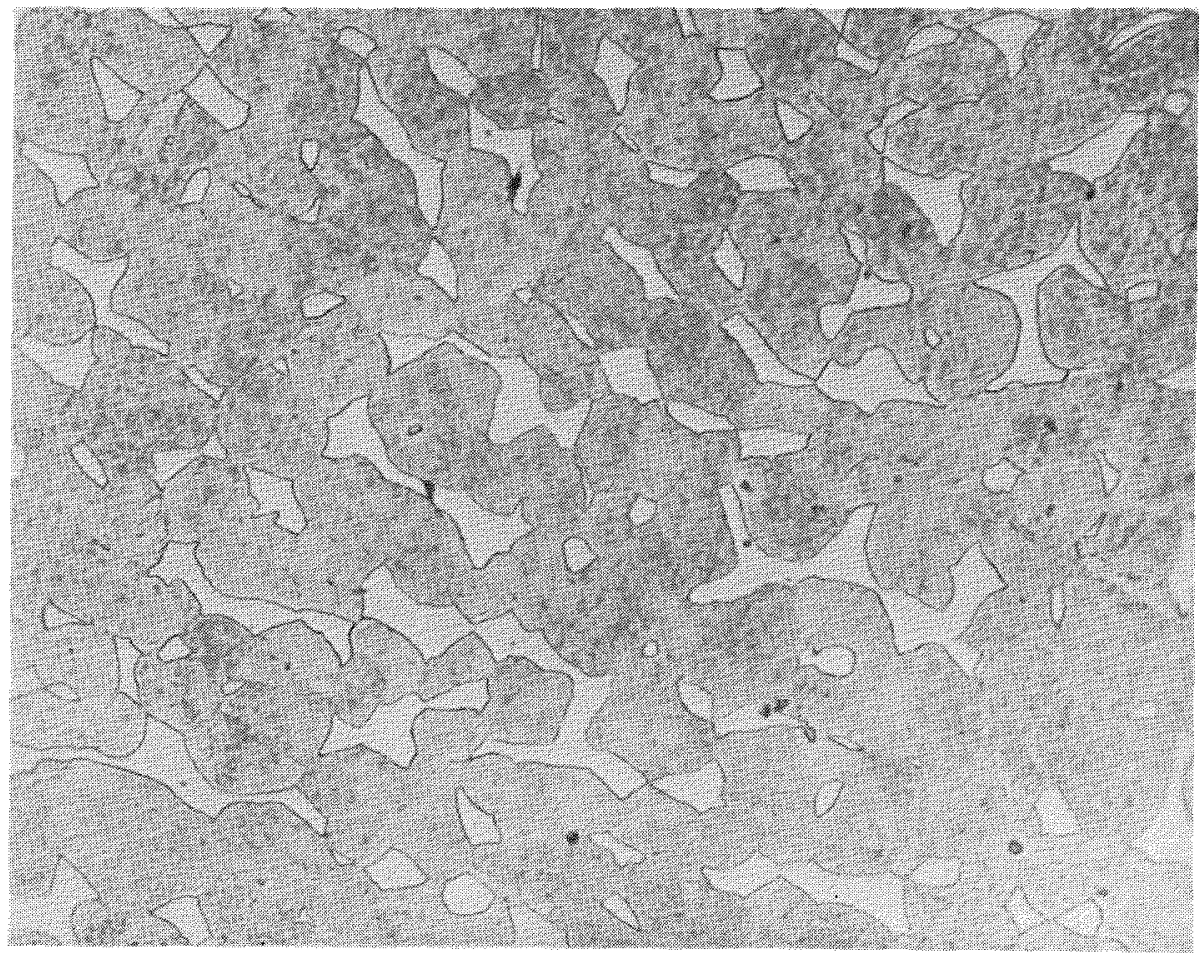

Mod. Vilella's Etch

Mag. 500X

At 1/4 Thickness

Figure 10. Microstructure Showing Delta Ferrite Stringers in a Transverse Section of Extra Low-Carbon AM-350 Bar $13 / 4$-Inch $\times 13 / 4$-Inch Thick (Heat 7C547) in AsReceived Condition (Top) and After Third Process M Braze (Bottom) 


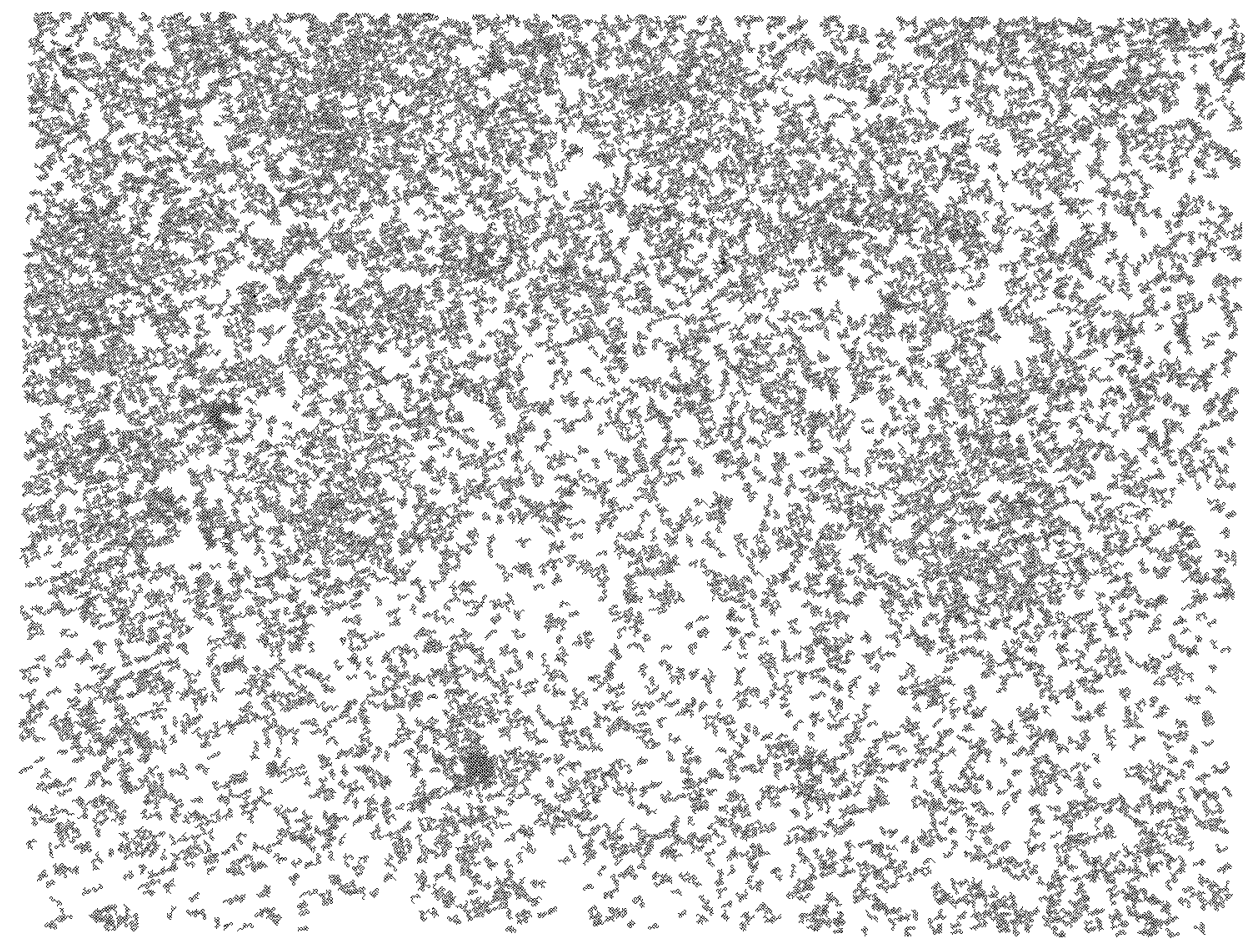

$2 \%$ Nital Etch

Mag. 500x At $1 / 4$ Thickness

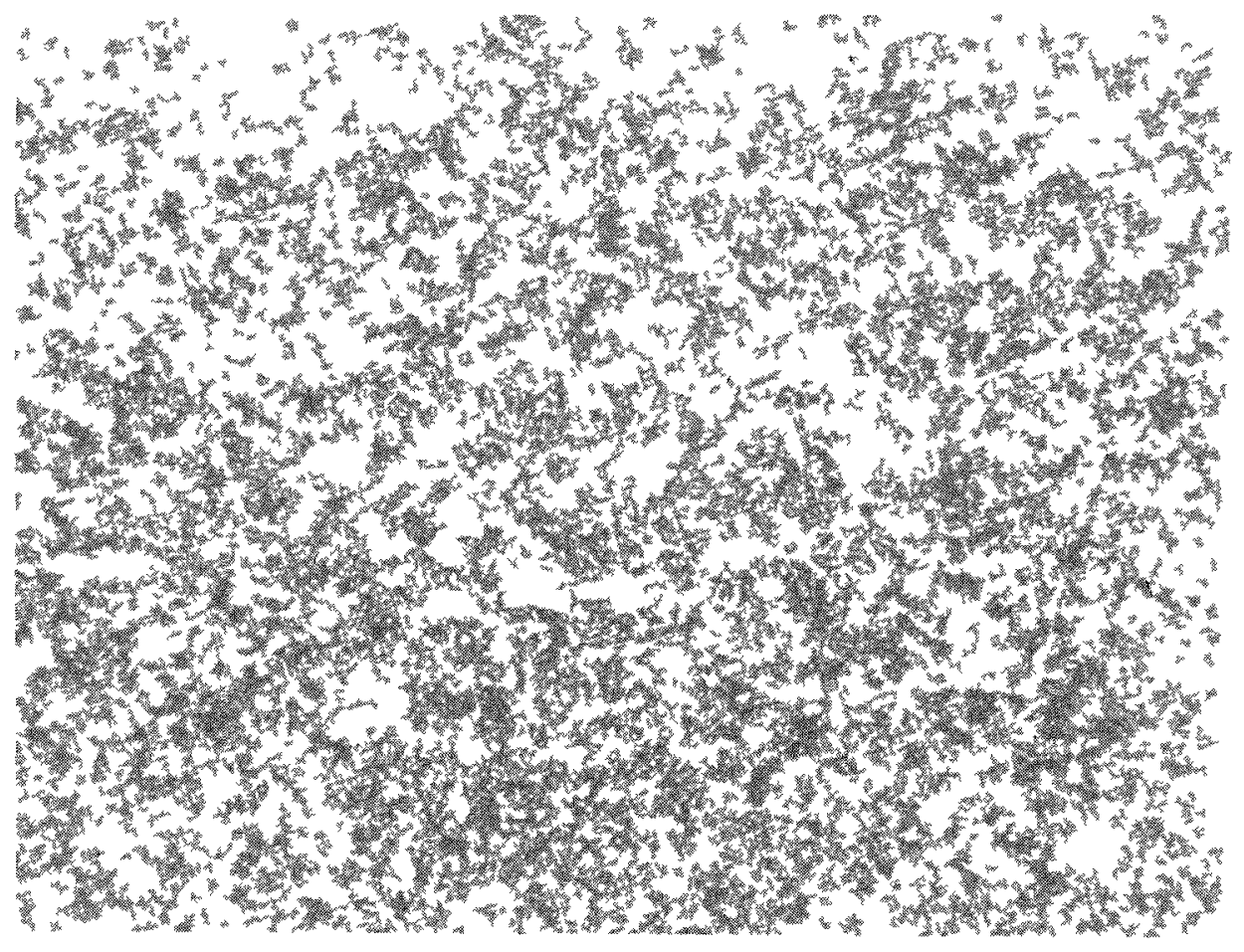

Mod. Vilella's Etch

Mag. $500 \mathrm{x}$

At $1 / 4$ Thickness

Figure 11. Microstructure Showing Various Types and Sizes of Carbide Particles and Very Fine-Grain Matrux in a Longitudinal Section of M2 Tool Steel Plate 3/4-Inch Thick (Heat 27433) in As-Received Condition (Top) and After Fourth Process M Braze (Bottom) 


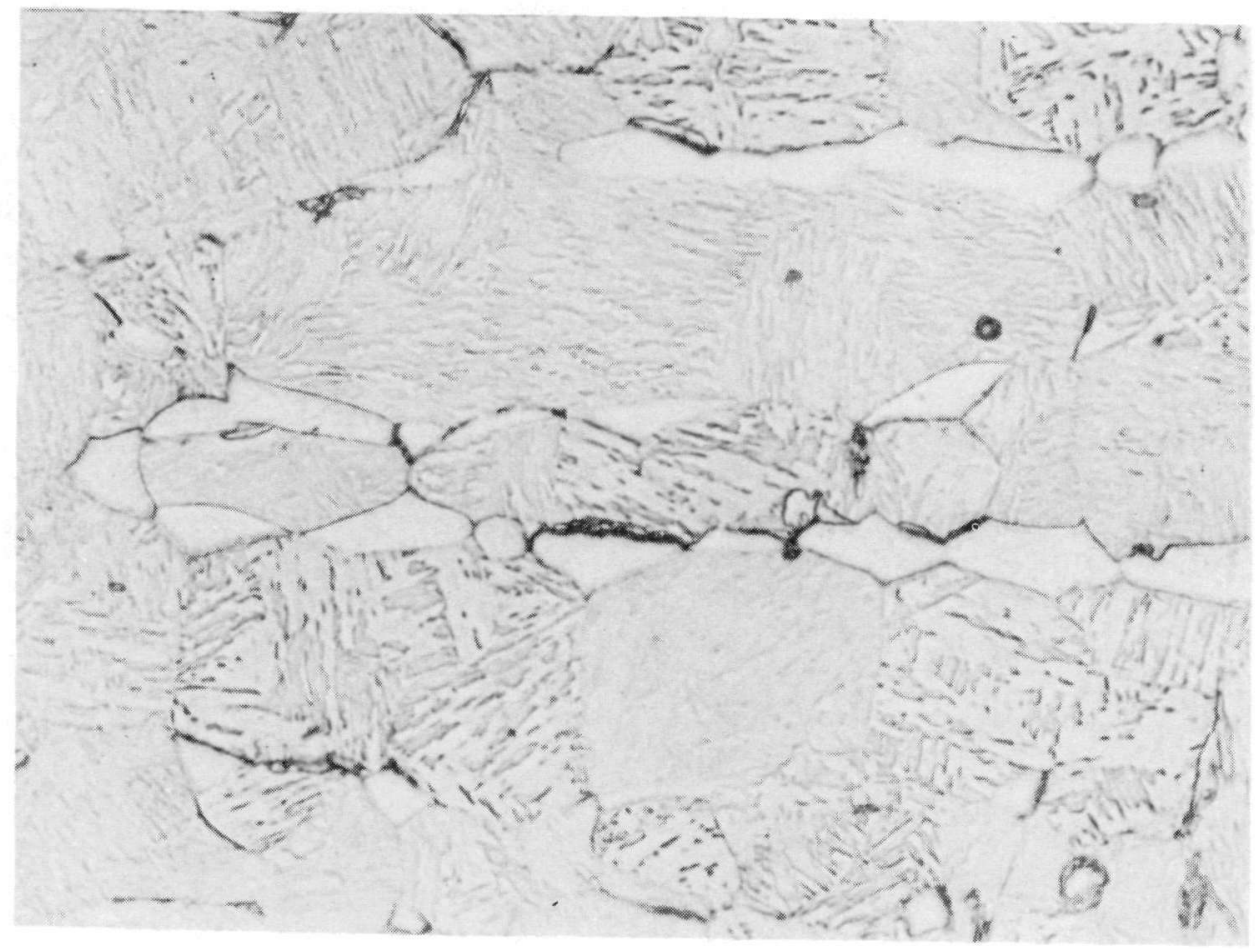

Mod. Vilella's Etch

Mag. 500X

At $1 / 4$ Thickness

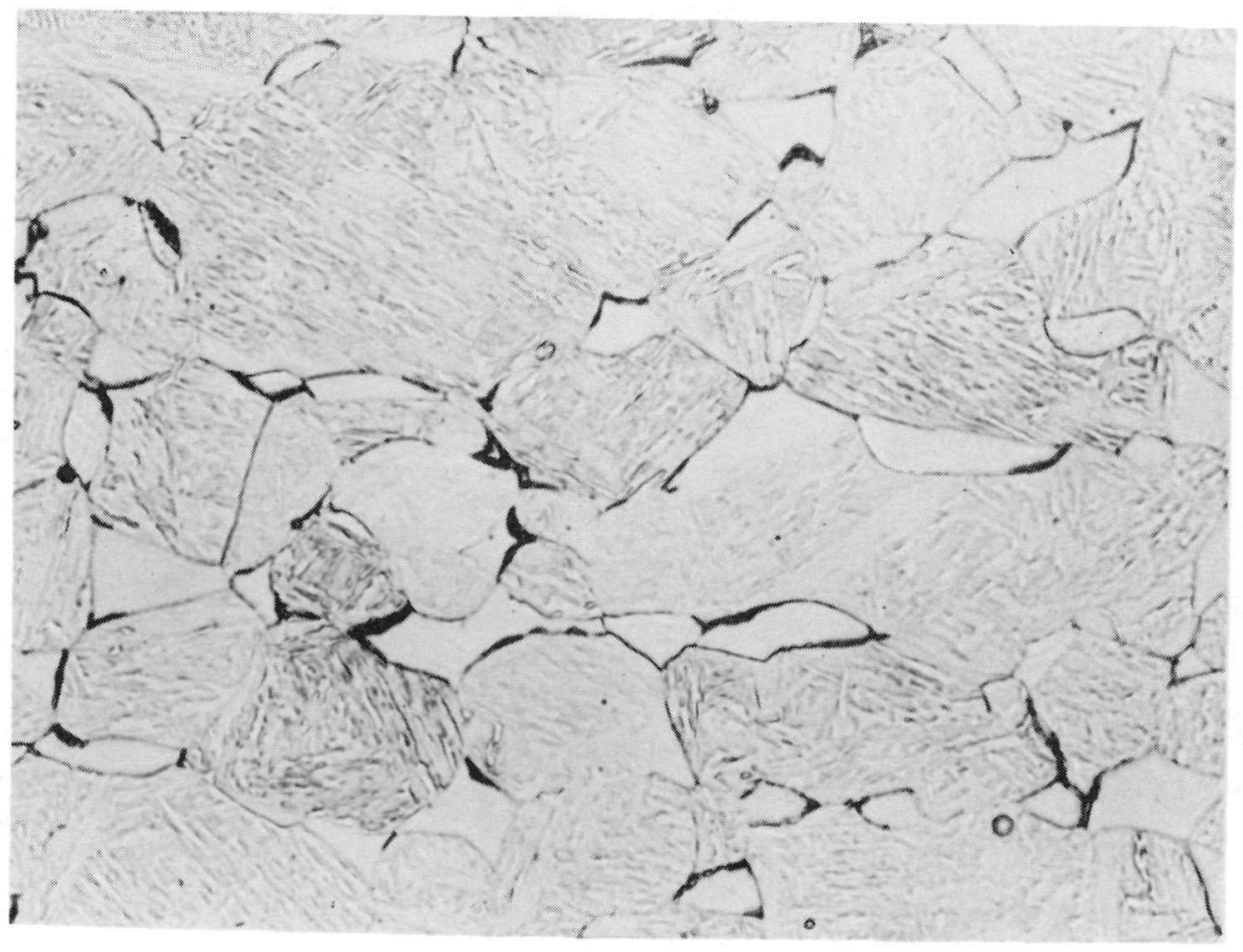

Mod. Vilella's Etch

Mag. 500X

At 1/4 Thickness

Figure 12. Microstructure Showing Remnants of Delta Ferrite Stringers in Longitudinal (Top) and Transverse (Bottom) Sections of AM-355 Plate 3/4-Inch Thick (Heat 27205) After 6 Hours at 2150 F with Sub-Zero Cool 


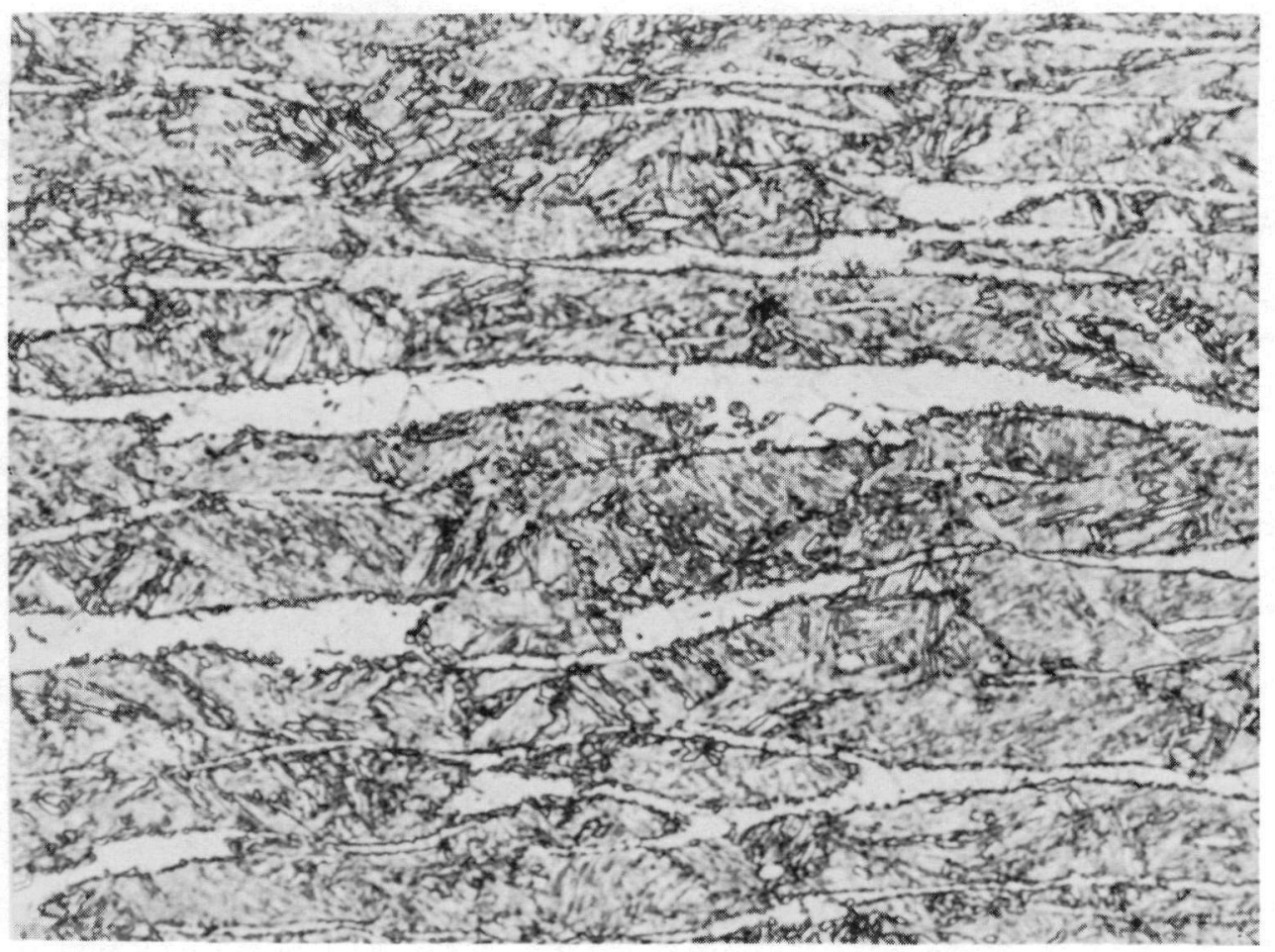

Mod. Vilella's Etch

Mag. 500X

At $1 / 4$ Thickness

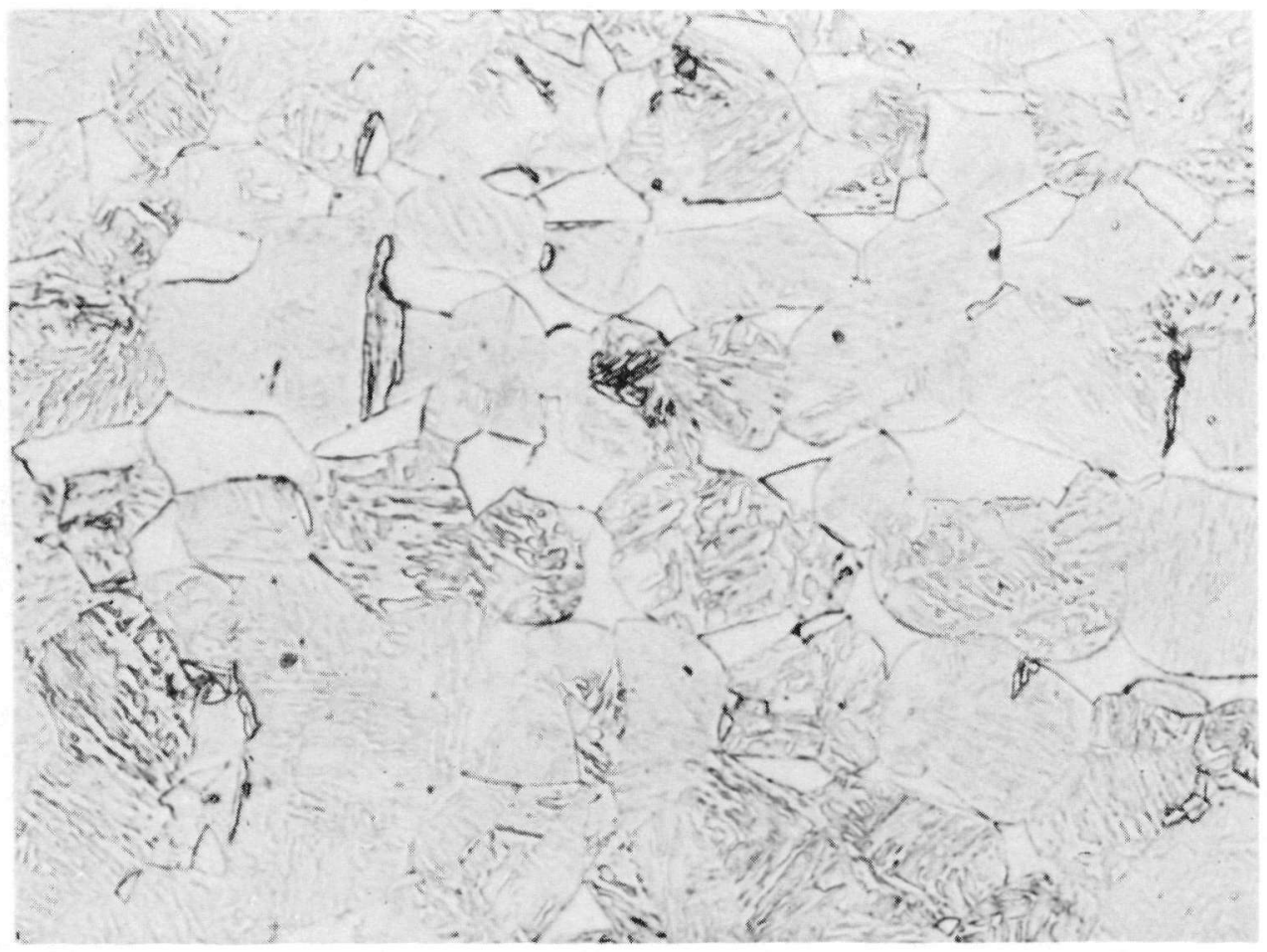

Mod. Vilella's Etch

Mag. 500X

At 1/4 Thickness

Figure 13. Microstructure Showing Delta Ferrite Stringers (Top) As-Received, and Remnants of Stringers (Bottom) After 6 Hours at 2150F with Sub-Zero Cool in Longitudinal Sections of Low-Carbon, Low-Nitrogen AM-350 Plate 3/4-Inch Thick (Heat 7C601) 


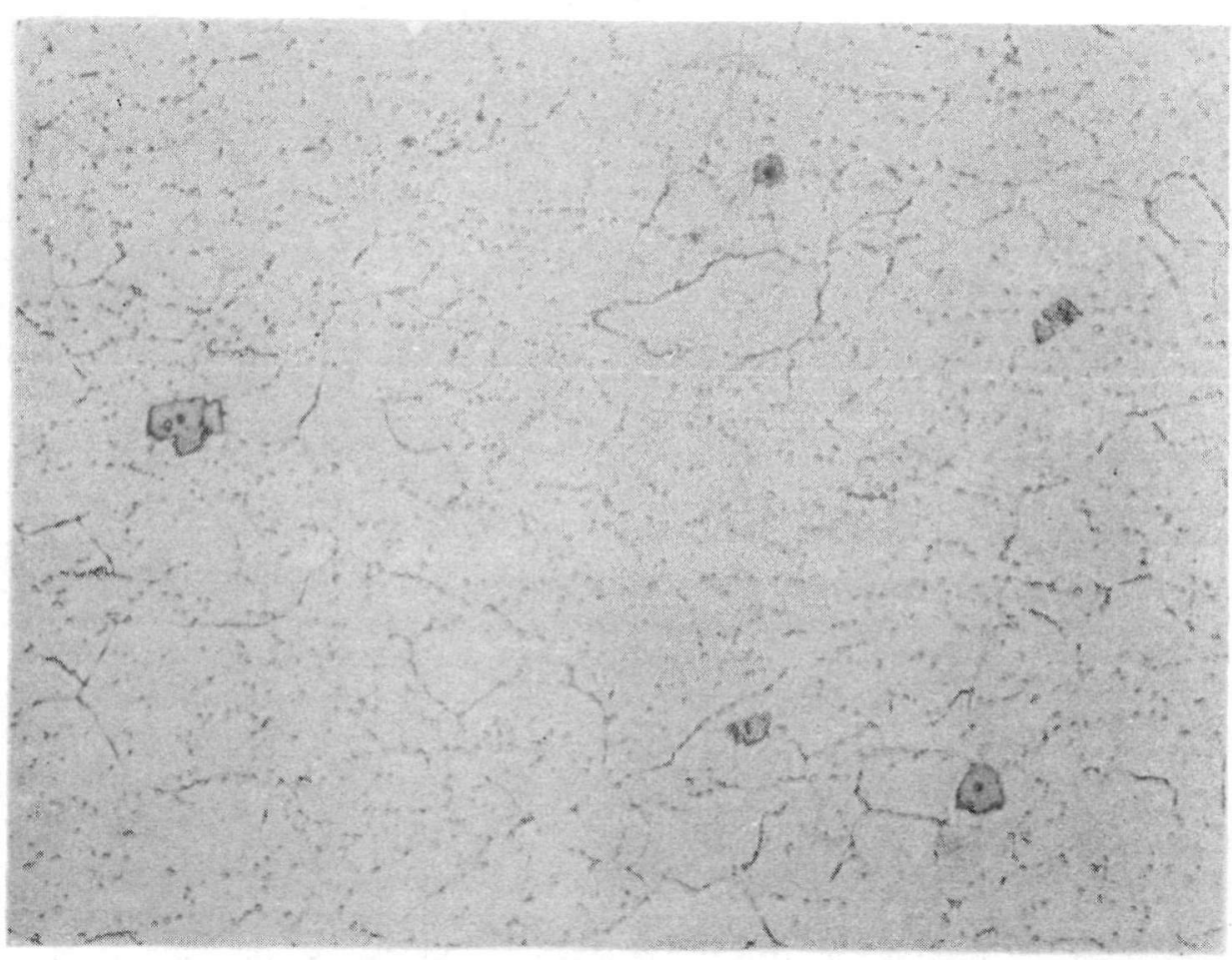

80\% Orthophosphoric Etch

Mag. 500X At $1 / 4$ Thickness

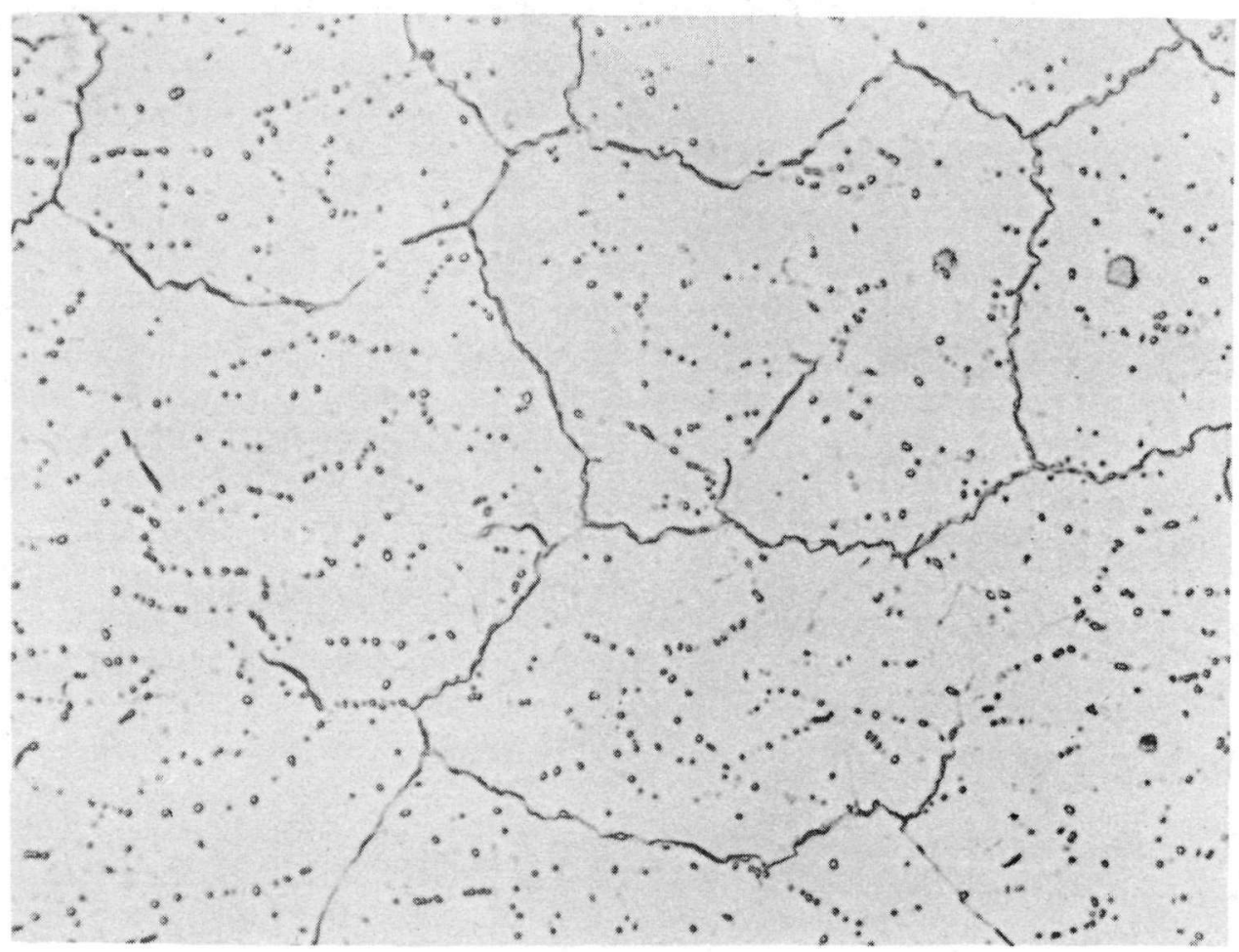

80\% Orthophosphoric Etch

Mag. 500X At 1/4 Thickness

Figure 14. Microstructure Showing Grain Size of Matrix in a Longitudinal Section of NiCrFe Alloy 600 Plate 3/4-Inch Thick (Heat NX0895) in As-Received Condition (Top) and After Third Process A Braze (Bottom) 


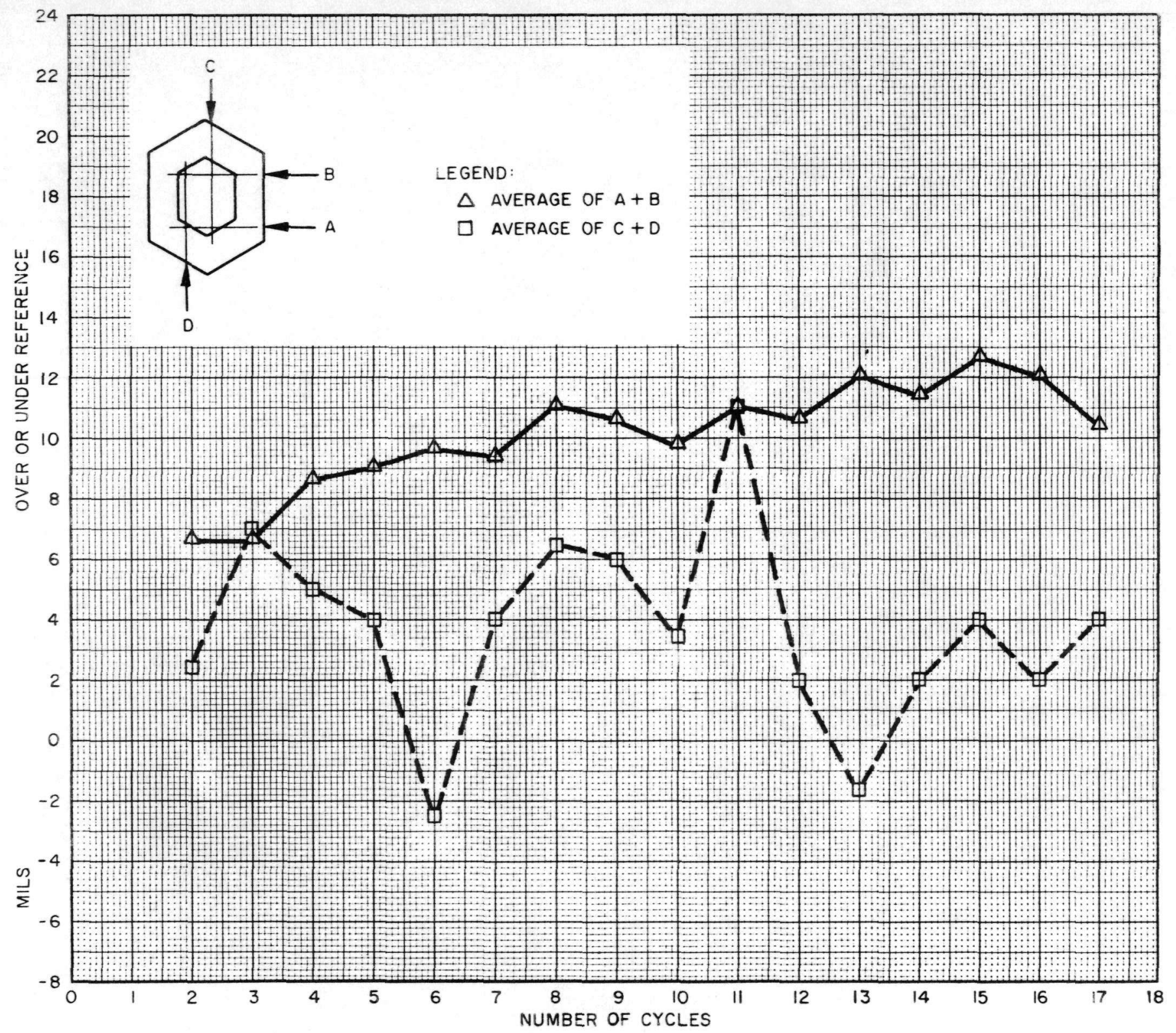

Figure 15. Process A-Dimensional Change versus Braze Cycles of Production Fixture Top Plate BA-2, $\mathrm{S} / \mathrm{N}-01$ 


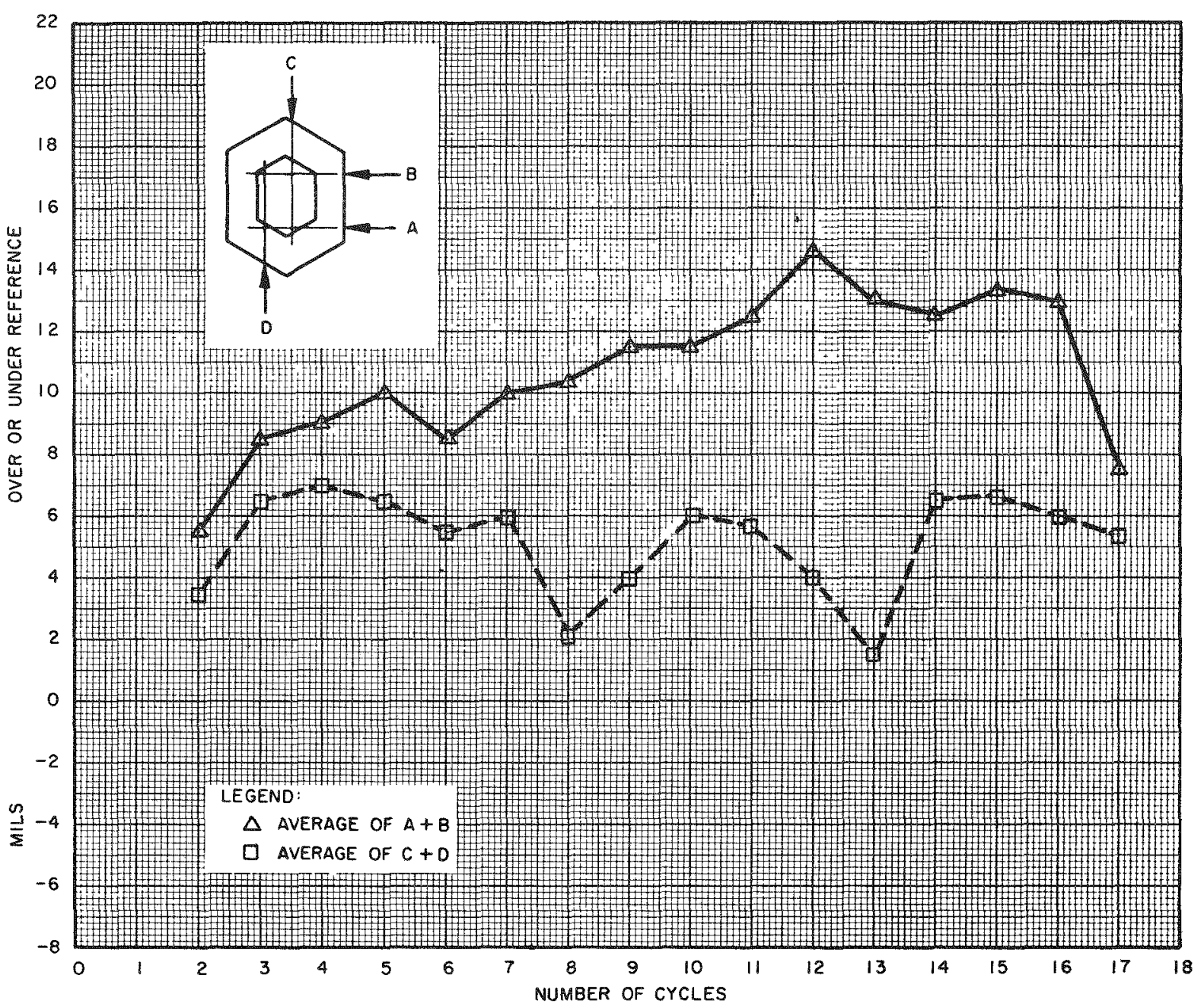




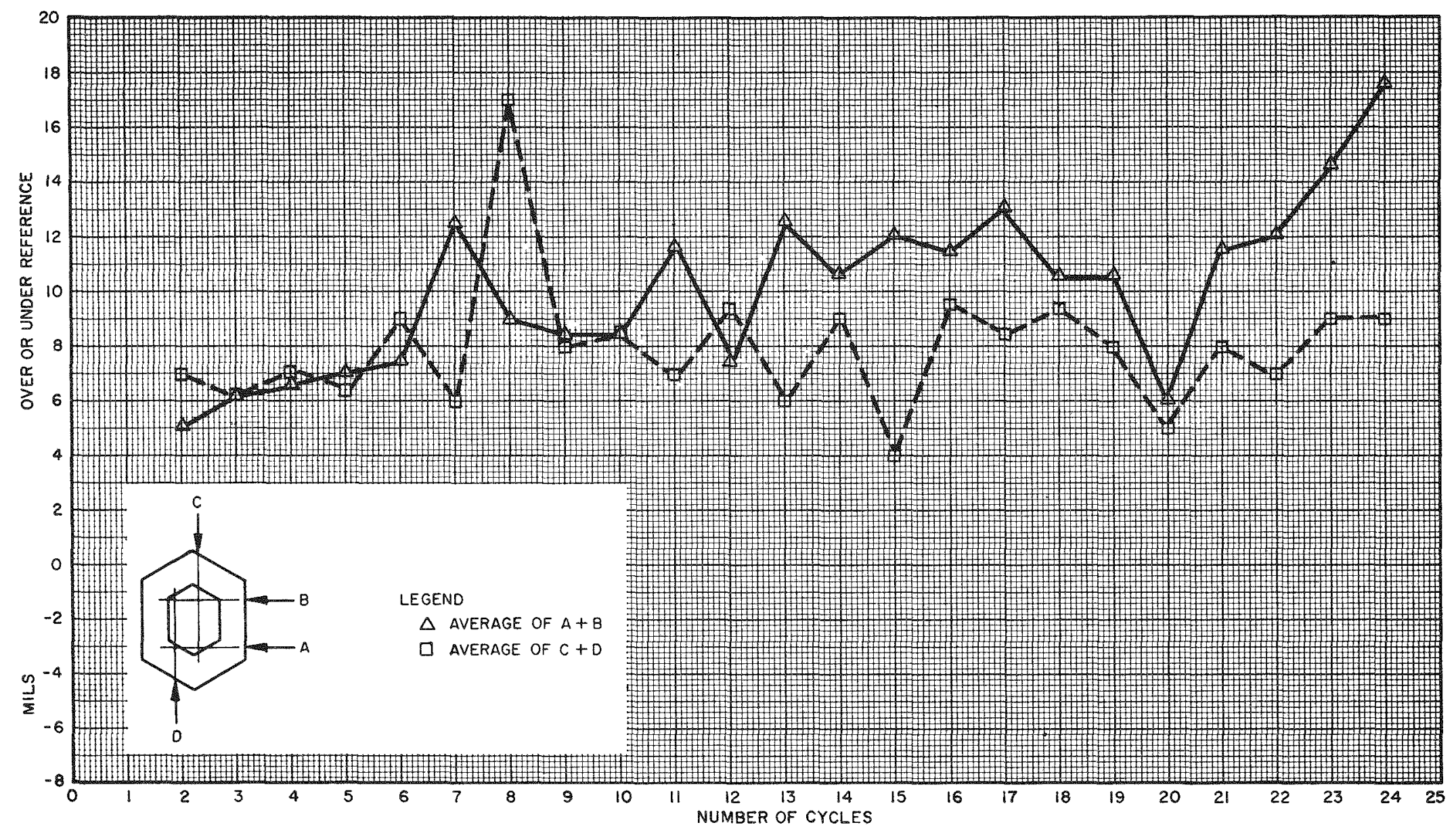

Figure 17. Process A-Dimensional Change versus Braze Cycles of Production Fixture Top Plate BA-1, $\mathrm{S} / \mathrm{N}-02$ 


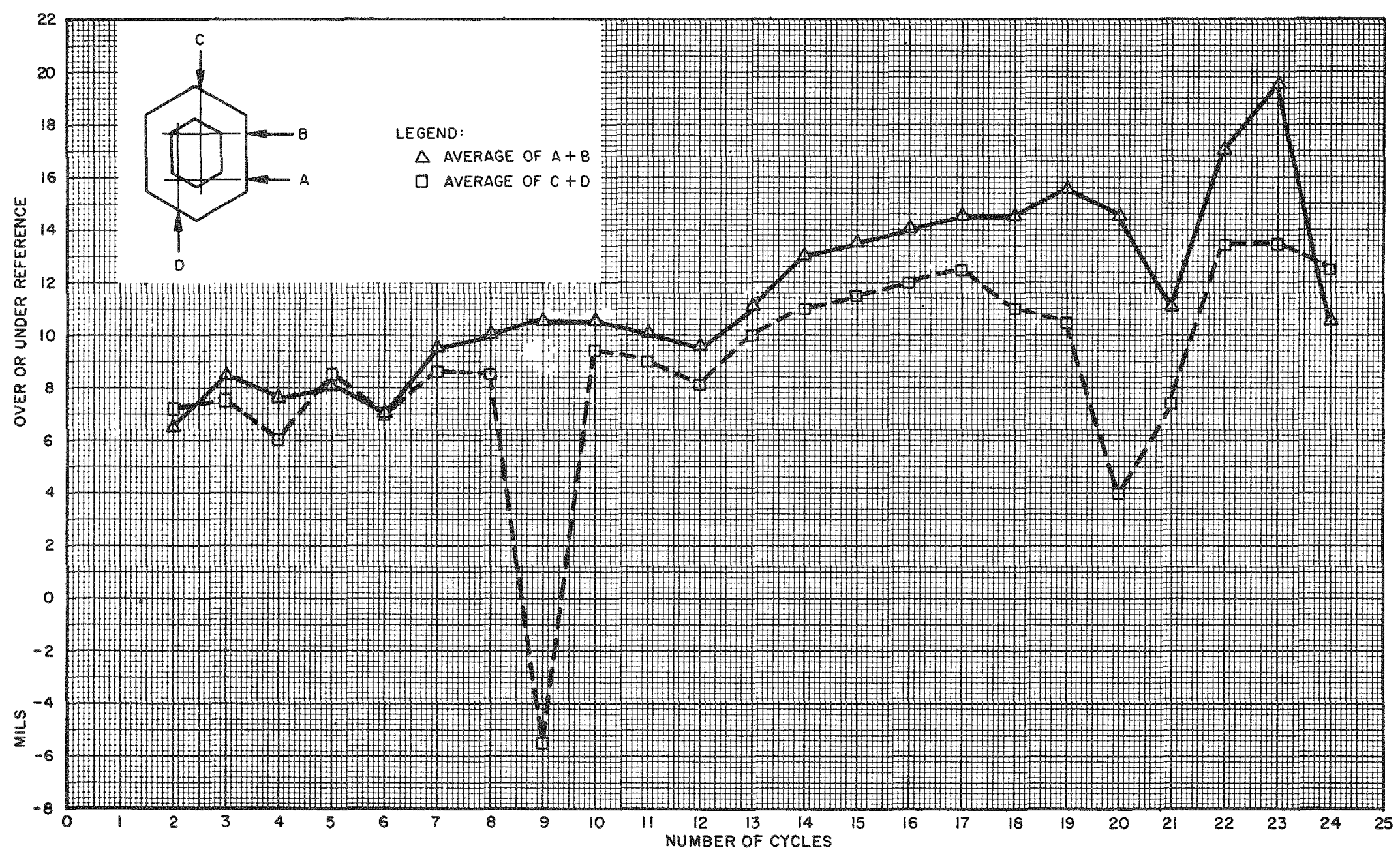

Figure 18. Process A-Dimensional Change versus Braze Cycles of Production Fixture Bottom Plate BA-1, $\mathrm{S} / \mathrm{N}-02$ 
TABLE 1. CARBON AND NITROGEN CONTENTS OF AM-350 SHEET SPECIMENS INVESTIGATED IN THE DILATOMETER TESTS PERFORMED AT THE BATTELLE MEMORIAL INSTITUTE

\begin{tabular}{ccccc}
$\begin{array}{c}\text { Transwerse } \\
\text { Specimen }\end{array}$ & & \multicolumn{2}{c}{$\begin{array}{c}\text { Composition (\%) } \\
\text { Nitrogen }\end{array}$} & \multicolumn{2}{c}{$\begin{array}{c}\text { Type of } \\
\text { AM-350 Sheet* }\end{array}$} \\
A & 0.076 & $\frac{0.070}{2}$ & & I \\
C & 0.043 & 0.042 & II \\
E & 0.019 & 0.030 & III
\end{tabular}

*Type refers to level of carbon and nitrogen contents 
TABLE 2. PROCESS M-DIMENSIONAL CHANGE TESTS ON BAR AND PLATE SPECIMENS VERSUS BRAZE CYCLES

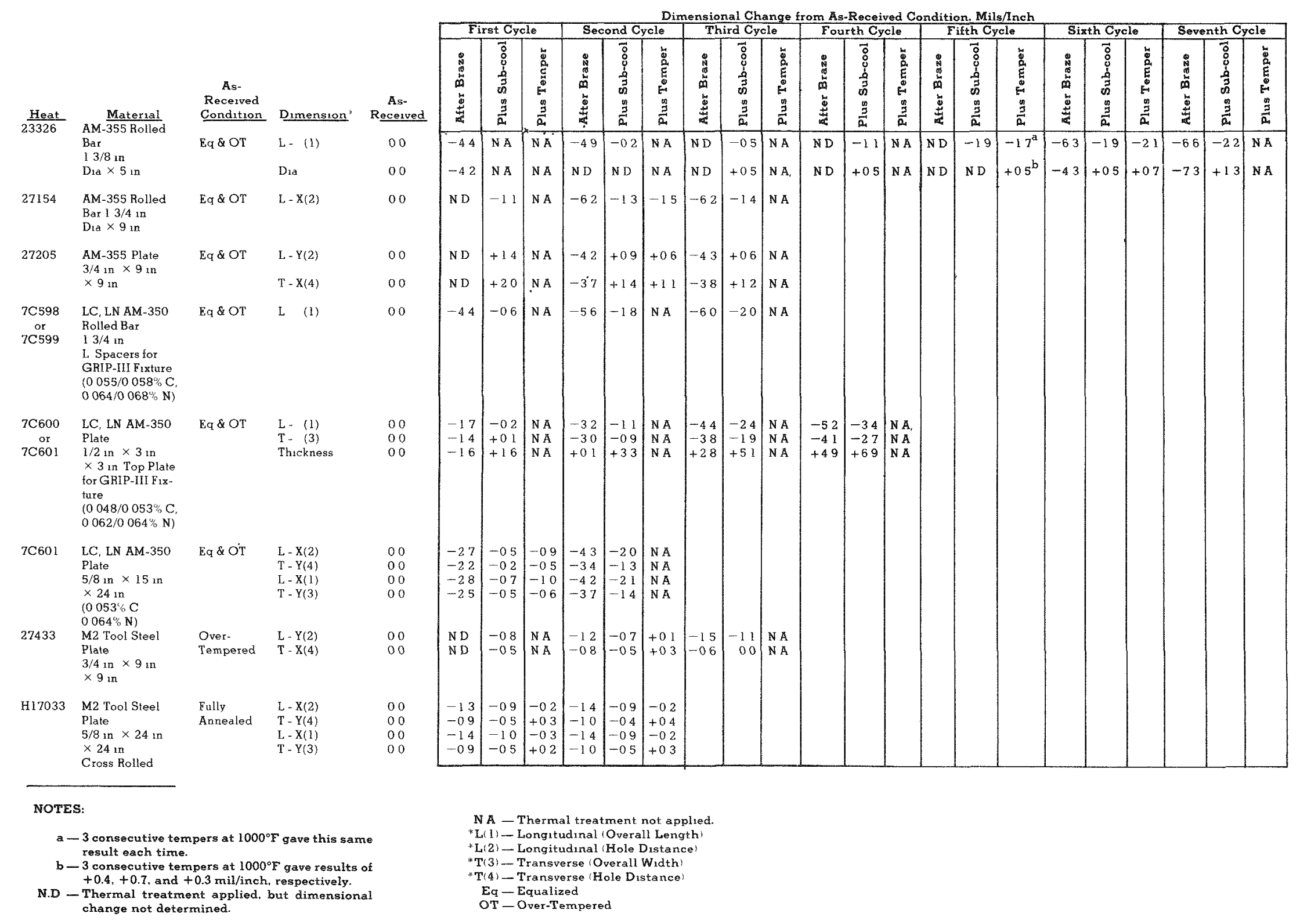



VERSUS BRAZE CYCLES

\begin{tabular}{|c|c|c|c|c|c|c|c|c|c|c|c|c|c|c|c|c|c|c|c|c|c|c|}
\hline \multirow[b]{3}{*}{ Feat } & \multirow[b]{3}{*}{ Material } & \multirow[b]{3}{*}{$\begin{array}{c}\text { As- } \\
\text { Received } \\
\text { Condition } \\
\end{array}$} & \multirow[b]{3}{*}{ Dimension* } & \multicolumn{19}{|c|}{ Dimensional Change from As-Received Condition, Mils/Inch } \\
\hline & & & & & \multicolumn{3}{|c|}{ First Cycle } & \multicolumn{3}{|c|}{ Second Cycle } & \multicolumn{3}{|c|}{ Third Cycle } & \multicolumn{3}{|c|}{ Fourth Cycle } & \multicolumn{3}{|c|}{ Fifth Cycle } & \multicolumn{3}{|c|}{ Sixth Cycle } \\
\hline & & & & $\begin{array}{c}\text { As. } \\
\text { Received }\end{array}$ & 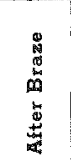 & 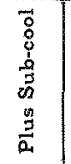 & 范 & 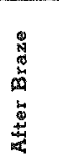 & 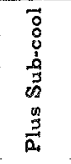 & 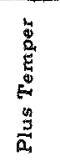 & 造 & 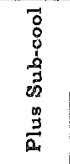 & 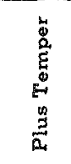 & 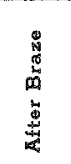 & 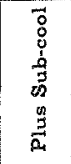 & 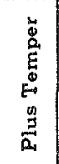 & 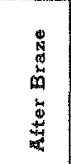 & 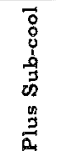 & 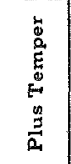 & 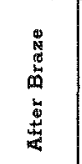 & 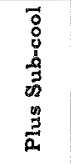 & 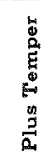 \\
\hline 27268 & $\begin{array}{l}\text { AM-355 Top Plate for } \\
218 \text {-Cell Blanket Array } \\
1 / 2 \text { in } \times 12 \text { in } \times 12 \text { in }\end{array}$ & $\mathrm{Eq} \& \mathrm{OT}$ & $\begin{array}{l}\mathrm{L}-\mathrm{Y}(1) \\
\mathrm{T} X(3)\end{array}$ & $\begin{array}{ll}0 & 0 \\
0 & 0\end{array}$ & $\begin{array}{l}\text { N D } \\
\text { N D }\end{array}$ & $\begin{array}{l}\text { ND } \\
\text { ND }\end{array}$ & $\begin{array}{l}\text { NA } \\
\text { NA }\end{array}$ & $\begin{array}{l}\text { ND } \\
\text { ND }\end{array}$ & $\begin{array}{l}-04 \\
-03\end{array}$ & $\begin{array}{l}\text { NA } \\
\text { NA }\end{array}$ & $\begin{array}{l}-55 \\
-48\end{array}$ & $\begin{array}{l}-14 \\
-11\end{array}$ & $\begin{array}{l}-13 \\
-10\end{array}$ & $\begin{array}{l}-57 \\
-51\end{array}$ & \begin{tabular}{|l|}
-15 \\
-14
\end{tabular} & $\begin{array}{l}\text { NA } \\
\text { NA }\end{array}$ & & & & & & \\
\hline 27268 & $\begin{array}{l}\text { AM-355 Bottom Plate for } \\
218 \text {-Cell Blanket Array } \\
1 / 2 \text { in } \times 12 \text { in } \times 12 \text { in }\end{array}$ & $\mathrm{Eq} \& \mathrm{OT}$ & $\begin{array}{l}\mathrm{L}-\mathrm{Y}(1) \\
\mathrm{T}-\mathrm{X}(3)\end{array}$ & $\begin{array}{l}00 \\
00\end{array}$ & $\begin{array}{l}\text { ND } \\
\text { ND }\end{array}$ & $\begin{array}{l}\text { ND } \\
\text { ND }\end{array}$ & $\begin{array}{l}\text { NA } \\
\text { NA }\end{array}$ & $\begin{array}{l}\text { ND } \\
\text { ND }\end{array}$ & $\begin{array}{l}-01 \\
+01\end{array}$ & $\begin{array}{l}\text { NA } \\
\text { NA }\end{array}$ & $\begin{array}{l}-50 \\
-47\end{array}$ & $\begin{array}{l}-05 \\
-06\end{array}$ & $\begin{array}{l}-07 \\
-09\end{array}$ & $\begin{array}{l}-51 \\
-44\end{array}$ & $\begin{array}{l}-10 \\
-10\end{array}$ & $\begin{array}{l}\mathrm{NA} \\
\mathrm{NA}\end{array}$ & & & & & & \\
\hline 26818 & $\begin{array}{l}\text { AM-355 Top Plate for } \\
\text { Seed Grid } \\
3 / 8 \text { in } \times 11 \text { in } \times 12 \text { in }\end{array}$ & $\mathrm{E}_{\mathrm{q}} \& \mathrm{OT}$ & $\begin{array}{l}\mathrm{L}-\mathbf{X}_{(2)} \\
\mathrm{T}-\mathrm{Y}(4)\end{array}$ & $\begin{array}{l}00 \\
00\end{array}$ & $\begin{array}{l}-41 \\
-39\end{array}$ & $\begin{array}{l}+08 \\
+07\end{array}$ & $\begin{array}{l}+04 \\
+03\end{array}$ & $\begin{array}{l}\text { ND } \\
\text { ND }\end{array}$ & $\begin{array}{l}\mathrm{NA} \\
\mathrm{NA}\end{array}$ & $\begin{array}{l}\text { NA } \\
\text { NA }\end{array}$ & $\begin{array}{l}\text { ND } \\
\text { ND }\end{array}$ & $\begin{array}{l}\text { NA } \\
\text { NA }\end{array}$ & $\begin{array}{l}\text { NA } \\
\text { NA }\end{array}$ & $\begin{array}{l}\text { ND } \\
\text { N D }\end{array}$ & $\begin{array}{l}\text { NA } \\
\text { NA }\end{array}$ & $\begin{array}{l}\mathrm{NA} \\
\mathrm{NA}\end{array}$ & $\begin{array}{l}-41 \\
-39\end{array}$ & $\begin{array}{l}+03 \\
+02\end{array}$ & $\begin{array}{r}+01 \\
0 \\
0\end{array}$ & $\begin{array}{l}-48 \\
-50\end{array}$ & $\begin{array}{l}+03 \\
+02\end{array}$ & $\begin{array}{l}\text { NA } \\
\text { NA }\end{array}$ \\
\hline 26818 & $\begin{array}{l}\text { AM-355 Botiom Plate for } \\
\text { Seed Grid } \\
3 / 8 \text { in } \times 11 \text { in } \times 12 \text { in }\end{array}$ & Eq \& OT & $\begin{array}{l}L-X(2) \\
T-Y(4)\end{array}$ & $\begin{array}{ll}0 & 0 \\
0 & 0\end{array}$ & $\begin{array}{l}-45 \\
-44\end{array}$ & 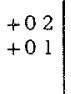 & $\begin{array}{rr}0 & 0 \\
-0 & 2\end{array}$ & $\begin{array}{l}\text { ND } \\
\text { N D }\end{array}$ & $\begin{array}{l}\mathrm{NA} \\
\mathrm{NA}\end{array}$ & $\begin{array}{l}\mathrm{NA} \\
\mathrm{NA}\end{array}$ & $\begin{array}{l}\text { ND } \\
\text { N D }\end{array}$ & $\begin{array}{l}\mathrm{NA} \\
\mathrm{NA}\end{array}$ & $\begin{array}{l}\mathrm{NA} \\
\mathrm{NA}\end{array}$ & $\begin{array}{l}\mathrm{ND} \\
\mathrm{ND}\end{array}$ & $\begin{array}{l}N \AA \\
N A\end{array}$ & $\begin{array}{l}\mathrm{NA} \\
\mathrm{NA}\end{array}$ & $\begin{array}{l}-44 \\
-44\end{array}$ & $\begin{array}{l}-02 \\
-03\end{array}$ & $\begin{array}{l}-05 \\
-06\end{array}$ & $\begin{array}{l}-53 \\
-56\end{array}$ & $\begin{array}{l}-01 \\
-08\end{array}$ & NA \\
\hline 27205 & $\begin{array}{l}\text { AM-355 Top Plate for } \\
\text { Reflector Grid } \\
1 / 2 \text { in } \times 11 \text { in } \\
\times 221 / 2 \text { in }\end{array}$ & Eq \& OT & $\begin{array}{l}\mathrm{L}-\mathrm{X}(2) \\
\mathrm{T}-\mathrm{Y}(4)\end{array}$ & $\begin{array}{l}00 \\
00\end{array}$ & $\begin{array}{l}-36 \\
-34\end{array}$ & $\begin{array}{l}+13 \\
+18\end{array}$ & $\begin{array}{l}+08 \\
+14\end{array}$ & & & & & & & & & & & & & & & \\
\hline 27205 & $\begin{array}{l}\text { AM-355 Boltom Plate } \\
\text { for Reflector Grid } \\
1 / 2 \text { in } \times 11 \text { in } \\
\times 221 / 2 \text { in }\end{array}$ & $\mathrm{Eq}_{\mathrm{q}} \& \mathrm{OT}$ & $\begin{array}{l}\mathrm{L}-\mathrm{X}(2) \\
\mathrm{T}-\mathrm{Y}(4)\end{array}$ & $\begin{array}{l}00 \\
00\end{array}$ & $\begin{array}{l}-36 \\
-33\end{array}$ & $\begin{array}{l}+11 \\
+16\end{array}$ & $\begin{array}{l}+07 \\
+12\end{array}$ & & & & & & & & & & & & & & & \\
\hline 26818 & $\begin{array}{l}\text { AM-355 Top Plate for } \\
\text { Blanket Grid } \\
7 / 16 \mathrm{in} \times 211 / 2 \mathrm{in} \\
\times 221 / 2 \mathrm{~m}\end{array}$ & $E_{q} \& O T$ & $\begin{array}{l}L-X(2) \\
T-Y(4)\end{array}$ & $\begin{array}{l}00 \\
00\end{array}$ & $\begin{array}{l}-38 \\
-34\end{array}$ & $\begin{array}{l}-05 \\
-03\end{array}$ & $\begin{array}{l}\text { NA } \\
\text { NA }\end{array}$ & & & & & & & & & & & & & & & \\
\hline 26818 & $\begin{array}{l}\text { AM-355 Bottom Plate } \\
\text { for Blanket Grid } \\
7 / 16 \text { in } \times 211 / 2 \text { in } \\
\times 22 \mathrm{l} / 2 \text { in }\end{array}$ & Eq \& OT & $\begin{array}{l}\mathrm{L}-\mathrm{X}(2) \\
\mathrm{T}-\mathrm{Y}(4)\end{array}$ & $\begin{array}{ll}0 & 0 \\
0 & 0\end{array}$ & $\begin{array}{l}-34 \\
-30\end{array}$ & $\begin{array}{l}-05 \\
-01\end{array}$ & $\begin{array}{l}\text { NA } \\
\text { NA }\end{array}$ & & & & & & & & & & & & & & & \\
\hline
\end{tabular}

NOTES ND - Thermal treatment applied. but dimensional change not determined

nent not applied

"-L/1)-Longitudinal Hole Distance'

- T (3) - Transverse / Hole Distance

- T 4 ) - Transverse (Overall Width

Eq-Equalized 
TABLE 4. PROCESS M-COMPARISON OF DIMENSIONAL CHANGE OF DILATOMETER TEST SPECIMENS AND PLATE SPECIMENS VERSUS BRAZE CYCLES

\begin{tabular}{|c|c|c|c|c|c|c|c|c|c|c|c|c|c|c|}
\hline \multirow[b]{3}{*}{ Heat } & \multirow[b]{3}{*}{ Material } & \multirow[b]{3}{*}{$\begin{array}{c}\text { As- } \\
\text { Received } \\
\text { Condition } \\
\end{array}$} & \multirow[b]{3}{*}{ Type of Specimen } & \multirow[b]{3}{*}{ Dimenston } & \multirow[b]{3}{*}{$\begin{array}{c}\begin{array}{c}\text { As- } \\
\text { Received }\end{array} \\
\end{array}$} & \multicolumn{9}{|c|}{ Dimensional Change from As-Received Condition, Mils/Inch } \\
\hline & & & & & & \multicolumn{3}{|c|}{ First Cycle } & \multicolumn{3}{|c|}{ Second Cycle } & \multicolumn{3}{|c|}{ Third Cycle } \\
\hline & & & & & & 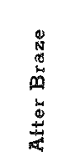 & 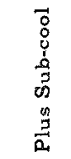 & 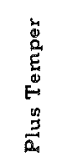 & 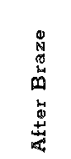 & 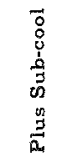 & 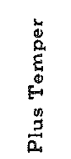 & 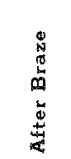 & 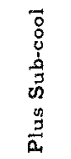 & 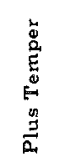 \\
\hline 27205 & AM-355 Plate $3 / 4$ in & Eq \& OT & $\begin{array}{l}\text { Dilatometer } 1 / 4 \text { in Dia } \\
\times 2 \mathrm{ma}\end{array}$ & $\begin{array}{l}\text { Long } \\
\text { Trans }\end{array}$ & $\begin{array}{l}00 \\
00\end{array}$ & $\begin{array}{l}-24 \\
-12\end{array}$ & $\begin{array}{l}+13 \\
+22\end{array}$ & $\begin{array}{l}\text { NA } \\
\text { NA }\end{array}$ & $\begin{array}{l}-32 \\
\mathrm{NA}\end{array}$ & $\begin{array}{l}+08 \\
\mathrm{NA}\end{array}$ & $\begin{array}{l}\text { NA } \\
\text { NA }\end{array}$ & $\begin{array}{l}-38 \\
\mathrm{NA}\end{array}$ & $\begin{array}{l}+04 \\
\mathrm{NA}\end{array}$ & $\begin{array}{l}\text { NA } \\
\text { NA }\end{array}$ \\
\hline 27205 & AM-355 Plate $3 / 4$ in & $\mathrm{Eq} \& \mathrm{OT}$ & Plate $3 / 4 \mathrm{in} \times 9 \mathrm{in} \times 9 \mathrm{in}$ & $\begin{array}{l}\text { Long } \\
\text { Trans }\end{array}$ & $\begin{array}{l}00 \\
00\end{array}$ & $\begin{array}{l}\text { ND } \\
\text { ND }\end{array}$ & $\begin{array}{l}+14 \\
+20\end{array}$ & $\begin{array}{l}\mathrm{NA} \\
\mathrm{NA}\end{array}$ & $\begin{array}{l}-42 \\
-37\end{array}$ & $\begin{array}{l}+09 \\
+14\end{array}$ & $\begin{array}{l}+06 \\
+11\end{array}$ & $\begin{array}{l}-43 \\
-38\end{array}$ & $\begin{array}{l}+06 \\
+12\end{array}$ & $\begin{array}{l}\text { NA } \\
\text { NA }\end{array}$ \\
\hline 27205 & AM-355 Plate $3 / 4$ in & $\mathrm{Eq}_{\mathrm{q}} \& \mathrm{OT}$ & $\begin{array}{l}\text { Reflector Fixture Top } \\
\& \text { Bottom Plates }\end{array}$ & $\begin{array}{l}\text { Long } \\
\text { Trans }\end{array}$ & $\begin{array}{l}00 \\
00\end{array}$ & $\begin{array}{l}-36 \\
-34\end{array}$ & $\begin{array}{l}+12 \\
+17\end{array}$ & $\begin{array}{l}+08 \\
+13\end{array}$ & $\begin{array}{l}\text { NA } \\
\text { NA }\end{array}$ & $\begin{array}{l}\mathrm{NA} \\
\mathrm{NA}\end{array}$ & $\begin{array}{l}\text { NA } \\
\text { NA }\end{array}$ & $\begin{array}{l}\mathrm{NA} \\
\mathrm{NA}\end{array}$ & $\begin{array}{l}\text { NA } \\
\text { NA }\end{array}$ & $\begin{array}{l}\text { NA } \\
\text { NA }\end{array}$ \\
\hline 7C601 & $\begin{array}{l}\text { LC, LN AMM-350 Plate } \\
3 / 4 \text { in }\end{array}$ & Eq \& OT & $\begin{array}{l}\text { Dilatometer } 1 / 4 \text { in Dia } \\
\times 2 \text { in }\end{array}$ & $\begin{array}{l}\text { Long } \\
\text { Trans }\end{array}$ & $\begin{array}{l}00 \\
00\end{array}$ & $\begin{array}{l}-23 \\
-15\end{array}$ & $\begin{array}{l}-03 \\
+06\end{array}$ & $\begin{array}{l}\mathrm{NA} \\
\mathrm{NA}\end{array}$ & $\begin{array}{l}-42 \\
\mathrm{NA}\end{array}$ & $\begin{array}{l}-18 \\
\mathrm{NA}\end{array}$ & $\begin{array}{l}\mathrm{NA} \\
\mathrm{NA}\end{array}$ & $\begin{array}{l}-55 \\
N A\end{array}$ & $\begin{array}{l}-32 \\
\mathrm{NA}\end{array}$ & $\begin{array}{l}N A \\
N A\end{array}$ \\
\hline 7C601 & $\begin{array}{l}\text { LC, LN AM-350 Plate } \\
3 / 4 \text { in }\end{array}$ & Eq \& OT & $\begin{array}{l}\text { Plate } 5 / 8 \mathrm{in} \times 15 \mathrm{nn} \\
\times 24 \mathrm{mn}\end{array}$ & $\begin{array}{l}\text { Long } \\
\text { Trans }\end{array}$ & $\begin{array}{l}00 \\
00\end{array}$ & $\begin{array}{l}-28 \\
-24\end{array}$ & $\begin{array}{l}-06 \\
-04\end{array}$ & $\begin{array}{l}-10 \\
-06\end{array}$ & $\begin{array}{l}-43 \\
-36\end{array}$ & $\begin{array}{l}-21 \\
-14\end{array}$ & $\begin{array}{l}\mathrm{NA} \bar{A} \\
\mathrm{~N} \bar{A}\end{array}$ & $\begin{array}{l}\text { NA } \\
\text { NA }\end{array}$ & $\begin{array}{l}\text { NA } \\
\text { NA }\end{array}$ & $\begin{array}{l}\text { N A } \\
\text { NA }\end{array}$ \\
\hline 27433 & M2 Tool Steel Plate 3/4 in & $\begin{array}{l}\text { Over- } \\
\text { Tempered }\end{array}$ & $\begin{array}{l}\text { Dilatometer } 1 / 4 \text { in } \\
\text { Dia } \times 2 \text { in }\end{array}$ & $\begin{array}{l}\text { Long } \\
\text { Trans }\end{array}$ & $\begin{array}{l}00 \\
00\end{array}$ & $\begin{array}{l}-12 \\
-08\end{array}$ & $\begin{array}{l}-06 \\
-02\end{array}$ & $\begin{array}{l}\text { NA } \\
\text { NA }\end{array}$ & $\begin{array}{l}-16 \\
\mathrm{NA}\end{array}$ & $\begin{array}{l}-09 \\
\text { NA }\end{array}$ & $\begin{array}{l}\text { NA } \\
\text { NA }\end{array}$ & $\begin{array}{l}-18 \\
\mathrm{NA}\end{array}$ & $\begin{array}{l}-11 \\
\mathrm{NA}\end{array}$ & $\begin{array}{l}\text { NA } \\
\text { NA }\end{array}$ \\
\hline 27433 & M2 Tool Steel Plate $3 / 4$ in & $\begin{array}{l}\text { Over- } \\
\text { Tempered }\end{array}$ & Plate $3 / 4$ in $\times 9$ m $\times 9_{1 \mathrm{n}}$ & $\begin{array}{l}\text { Long } \\
\text { Trans }\end{array}$ & 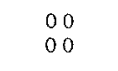 & $\begin{array}{l}\text { ND } \\
\text { ND }\end{array}$ & $\begin{array}{l}-08 \\
-05\end{array}$ & $\begin{array}{l}\text { NA } \\
\text { NA }\end{array}$ & $\begin{array}{l}-12 \\
-08\end{array}$ & $\begin{array}{l}-07 \\
-05\end{array}$ & $\begin{array}{l}+01 \\
+03\end{array}$ & $\begin{array}{l}-15 \\
-06\end{array}$ & $\begin{array}{rl}-1 & 1 \\
0 & 0\end{array}$ & $\begin{array}{l}\mathrm{NA} \\
\mathrm{NA}\end{array}$ \\
\hline HI 7033 & M2 Tool Steel Plate 3/4 in & $\begin{array}{l}\text { Fully } \\
\text { Annealed }\end{array}$ & $\begin{array}{l}\text { Dilatometer } 1 / 4 \text { in Dia } \\
\times 2 \text { in }\end{array}$ & $\begin{array}{l}\text { Long } \\
\text { Trans }\end{array}$ & $\begin{array}{l}00 \\
00\end{array}$ & $\begin{array}{l}-15 \\
-10\end{array}$ & $\begin{array}{l}-13 \\
-06\end{array}$ & $\begin{array}{l}\mathrm{NA} \\
\mathrm{N} A\end{array}$ & $\begin{array}{l}-22 \\
-08\end{array}$ & $\begin{array}{l}-18 \\
\mathrm{NA}\end{array}$ & $\begin{array}{l}\text { NA } \\
\text { NA }\end{array}$ & $\begin{array}{l}-23 \\
-12\end{array}$ & $\begin{array}{l}-18 \\
-08\end{array}$ & $\begin{array}{l}\text { NA } \\
\text { NA }\end{array}$ \\
\hline H17033 & M2 Tool Steel Plate $3 / 4$ !n & $\begin{array}{l}\text { Fully } \\
\text { Annealed }\end{array}$ & $\begin{array}{l}\text { Plate } 5 / 8 \text { in } \times 24 \text { in } \\
\times 24 \text { in Cross Rolled }\end{array}$ & $\begin{array}{l}\text { Long } \\
\text { Trans }\end{array}$ & $\begin{array}{l}00 \\
00\end{array}$ & $\begin{array}{l}-14 \\
-09\end{array}$ & $\begin{array}{l}-10 \\
-05\end{array}$ & $\begin{array}{l}-03 \\
+03\end{array}$ & $\begin{array}{l}-14 \\
-10\end{array}$ & $\begin{array}{l}-09 \\
-05\end{array}$ & $\begin{array}{l}-02 \\
+04\end{array}$ & $\begin{array}{l}\mathrm{NA} \\
\mathrm{NA}\end{array}$ & $\begin{array}{l}\text { NA } \\
\text { NA }\end{array}$ & $\begin{array}{l}\text { NA } \\
\text { NA }\end{array}$ \\
\hline
\end{tabular}

NOTE: N.D. - Thermal treatment applied, but dimensional change not determined N.A. - Thermal treatment not applied.

Long. - Longitudinal

Trans. - Transverse

Eq - Equalized
OT-Over.Tempered 
TABLE 5. PROCESS M-DIMENSIONAL RESTORATION THERMAL TREATMENT EXPERIMENTS TO PRODUCE EXPANSION FOR OFFSETTING CUMULATIVE SHRINKAGE

\begin{tabular}{|c|c|c|}
\hline Heat & Material & Dimension \\
\hline 23326 & $\begin{array}{l}\text { AM-355 Rolled Bar } \\
13 / 8 \text { !n Dia } \times 5 \text { !n }\end{array}$ & $\begin{array}{l}\text { L - (2) } \\
\text { Dia }\end{array}$ \\
\hline 27154 & $\begin{array}{l}\text { AM-355 Rolled Bar } 13 / 4 \text { in Dia } \\
\times 9 \text { in }\end{array}$ & $L-X(1)$ \\
\hline 27205 & $\begin{array}{l}\text { AM-355 Plate } \\
3 / 4 \mathrm{~m} \times 9 \mathrm{~m} \times 9 \mathrm{un}\end{array}$ & $\begin{array}{l}\mathrm{L}-\mathrm{Y}(1) \\
\mathrm{T}-\mathrm{X}(3)\end{array}$ \\
\hline 27268 & $\begin{array}{l}\text { AM-355 Bottom Plate for 218-Cell } \\
\text { Blanket Array }\end{array}$ & $\begin{array}{l}L-Y(1) \\
T-X(3)\end{array}$ \\
\hline 26818 & AM 355 Top Plate for Seed Grid & $\begin{array}{l}\mathrm{L}-\mathrm{X}(2) \\
\mathrm{T}-\mathrm{Y}(4)\end{array}$ \\
\hline 26818 & AM-355 Bottom Plate for Seed Grid & $\begin{array}{l}\mathrm{L}-\mathrm{X}(2) \\
\mathrm{T}-\mathrm{Y}(4)\end{array}$ \\
\hline 7C547 & $\begin{array}{l}\text { XLC AM-350 Rolled Bar }-13 / 4 \text { in } \\
\times 13 / 4 \text { in } \times 9 \text { in }(0028 \% \mathrm{C} \\
0054 \% \mathrm{~N})\end{array}$ & $\mathrm{L}-\mathrm{X}(1)$ \\
\hline $\begin{array}{l}7 \mathrm{7C598} \\
\text { or } \\
7 \mathrm{C} 599\end{array}$ & $\begin{array}{l}\text { LC LN AM-350 Rolled Bar } 13 / 4 \mathrm{in} \\
\text { Long Spacers for GRIP-III Faxture } \\
(0055 / 0058 \% \text { C } 0064 / 0 \text { 068\% N) }\end{array}$ & L - (2) \\
\hline $\begin{array}{l}7 \mathrm{C} 600 \\
\text { or } \\
7 \mathrm{C} 601\end{array}$ & $\begin{array}{l}\text { LC LN AM-350 Plate } 1 / 2 \text { in } \times 3 \text { in } \\
\times 3 \text { in Top Plate for GRIP-III Fix- } \\
\text { ture }(00480053 \% \mathrm{C} \\
0062 / 0064 \% \mathrm{~N})\end{array}$ & $\begin{array}{l}L \quad(2) \\
T-(4) \\
\text { Thickness }\end{array}$ \\
\hline 7C601 & $\begin{array}{l}\text { LC LN AM-350 Plate } 5 / 8 \text { in } \\
\times 15 \mathrm{in} \times 24 \text { in }(0053 \% \mathrm{C} \\
0064 \% \mathrm{~N})\end{array}$ & $\begin{array}{l}\mathrm{L}-\mathrm{X}(1) \\
\mathrm{T}-\mathrm{Y}(3) \\
\mathrm{L}-\mathrm{X}(2) \\
\mathrm{T}-\mathrm{Y}(4)\end{array}$ \\
\hline 27433 & $\begin{array}{l}\text { M2 Tool Steel Plate } 3 / 4 \text { in } \times 9 \text { in } \\
\times 9 \text { in }\end{array}$ & $\begin{array}{l}\mathrm{L}-\mathrm{Y}(1) \\
\mathrm{T}-\mathrm{X}(3)\end{array}$ \\
\hline
\end{tabular}

Prior Condition 7th Braze + Sub-cool 7th Braze + Sub-cool 3rd Braze + Sub-coo 3rd Braze + Sub-cool 3rd Braze + Sub-cool 4 th Braze + Sub-cool 4 th Braze + Sub-cool

11 th Braze + Sub-cool 11th Braze + Sub-cool 11 th Braze + Sub-cool 3rd Braze + Sub-cool 3rd Braze + Sub-cool th Braze + Sub-cool 4th Braze + Sub-cool
4th Braze + Subcool 4th Braze + Sub-cool

2nd Braze + Sub-cool 2nd Braze + Sub-cool 2nd Braze + Sub-cool 2nd Braze + Sub-cool 3rd Braze + Sub-cool

\begin{tabular}{|c|c|c|c|c|c|c|c|c|c|c|c|c|c|c|c|c|c|}
\hline \multicolumn{13}{|c|}{ iona } & \multirow[b]{2}{*}{$\begin{array}{c}\text { Next } \\
\end{array}$} & \multicolumn{2}{|c|}{ Braze Cycle } & \multicolumn{2}{|c|}{$\begin{array}{l}\text { Dimensional } \\
\text { Restoration } \\
\text { Thermal } \\
\text { Treatment } \\
\text { Experiments }\end{array}$} \\
\hline 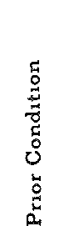 & 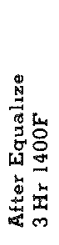 & 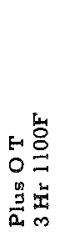 & 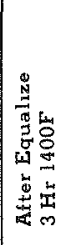 & 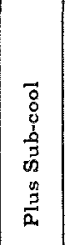 & 㟶 & 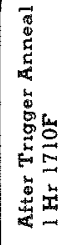 & 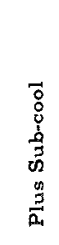 & 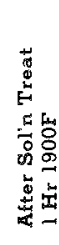 & 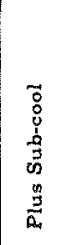 & $\begin{array}{l}\overrightarrow{0} \\
0 \\
0 \\
0 \\
0 \\
0 \\
02 \\
3 \\
\vec{a}\end{array}$ & 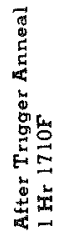 & 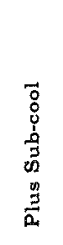 & & 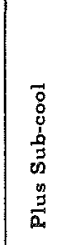 & 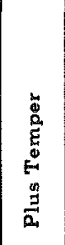 & 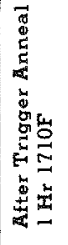 & $\begin{array}{l}\overrightarrow{0} \\
0 \\
0 \\
0 \\
03 \\
0 \\
0 \\
\overrightarrow{0}\end{array}$ \\
\hline $\begin{array}{l}-22 \\
+13\end{array}$ & $\begin{array}{r}-09 \\
+24\end{array}$ & $\begin{array}{l}-22 \\
+13\end{array}$ & $\begin{array}{l}-18 \\
+16\end{array}$ & \begin{tabular}{|}
-16 \\
+18
\end{tabular} & $\begin{array}{l}A \\
\text { NA }\end{array}$ & $\begin{array}{l}\text { NA } \\
\text { NA }\end{array}$ & \begin{tabular}{|l|}
$\mathrm{NA}$ \\
$\mathrm{NA}$
\end{tabular} & $\begin{array}{l}-57 \\
-20\end{array}$ & $\begin{array}{l}-19 \\
+16\end{array}$ & $\begin{array}{l}\mathrm{N} A \\
\mathrm{~N} A\end{array}$ & $\begin{array}{l}\text { ND } \\
\text { N D }\end{array}$ & $\begin{array}{l}-09 \\
+34\end{array}$ & & & & & \\
\hline-14 & $\mathrm{NA}$ & $\mathrm{NA}$ & -03 & -02 & $\mathrm{NA}$ & $\mathrm{NA}$ & $\mathrm{NA}$ & $\mathrm{NA}$ & N A & N $A$ & $\mathrm{NA}$ & NA & -67 & -18 & NA & ND & -05 \\
\hline $\begin{array}{l}+06 \\
+12\end{array}$ & $\begin{array}{l}\text { N A } \\
\text { N A }\end{array}$ & $\begin{array}{l}\text { NA } \\
\text { N A }\end{array}$ & $\begin{array}{l}+14 \\
+20\end{array}$ & {$\left[\begin{array}{ll}+1 & 4 \\
+2 & 1\end{array}\right.$} & $\begin{array}{l}\text { NA } \\
N \AA\end{array}$ & $\begin{array}{l}\text { NA } \\
\text { NA }\end{array}$ & $\begin{array}{l}\text { NA } \\
\text { NA }\end{array}$ & $\begin{array}{l}\text { N } A \\
N A\end{array}$ & $\begin{array}{l}\text { NA } \\
\text { NA }\end{array}$ & $\begin{array}{l}\text { NA } \\
\text { NA }\end{array}$ & $\begin{array}{l}\text { NA } \\
\text { NA }\end{array}$ & $\begin{array}{l}\text { NA } \\
\text { NA }\end{array}$ & $\begin{array}{l}-52 \\
-46\end{array}$ & $\begin{array}{l}+01 \\
+09 \\
+09\end{array}$ & \begin{tabular}{|l|} 
N A \\
N $\bar{A}$
\end{tabular} & $\begin{array}{l}\text { ND } \\
\text { N D }\end{array}$ & $\begin{array}{l}+05 \\
+17\end{array}$ \\
\hline $\begin{array}{l}-10 \\
-10\end{array}$ & $\begin{array}{l}\text { N A } \\
\text { N A }\end{array}$ & $\begin{array}{l}\text { N A } \\
\text { N A }\end{array}$ & $\mid \begin{array}{l}-07 \\
-02\end{array}$ & 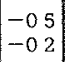 & $\begin{array}{l}\text { NA } \\
\text { NA }\end{array}$ & $\begin{array}{l}\mathrm{NA} \\
\mathrm{NA}\end{array}$ & $\begin{array}{l}\text { NA } \\
\text { NA }\end{array}$ & $\begin{array}{l}-61 \\
-45\end{array}$ & $\begin{array}{ll}-14 \\
-01\end{array}$ & $\begin{array}{l}\text { N A } \\
\text { N A }\end{array}$ & & & & & & & \\
\hline $\begin{array}{l}-08 \\
-15\end{array}$ & $\begin{array}{l}\text { NA } \\
\text { NA }\end{array}$ & $\begin{array}{l}\text { N A } \\
\text { N A }\end{array}$ & $\begin{array}{l}\mathrm{NA} \\
\mathrm{NA}\end{array}$ & $\begin{array}{l}\text { NA } \\
\text { NA }\end{array}$ & $\begin{array}{l}\text { NA } \\
\text { NA }\end{array}$ & $\begin{array}{l}\mathrm{ND} \\
\mathrm{ND}\end{array}$ & $\begin{array}{l}+03 \\
-03\end{array}$ & & & & & & & & & & \\
\hline $\begin{array}{l}-13 \\
-21\end{array}$ & $\begin{array}{l}\text { NA } \\
\text { NA }\end{array}$ & $\begin{array}{l}\text { N A } \\
\text { N A }\end{array}$ & $\begin{array}{l}\text { NA } \\
\text { NA }\end{array}$ & $\begin{array}{l}\mathrm{N} A \\
\mathrm{NA}\end{array}$ & $\begin{array}{l}\text { NA } \\
\text { NA }\end{array}$ & $\begin{array}{l}\text { ND } \\
\text { N D }\end{array}$ & $\begin{array}{r}00 \\
-10\end{array}$ & & & & & & & & & & \\
\hline-10 & $\mathrm{NA}$ & $\mathrm{NA}$ & -21 & -17 & $\mathrm{~N}$ A & NA & NA & $\mathrm{NA}$ & N A & NA & $\mathrm{NA}$ & $\mathrm{NA}$ & -22 & -15 & NA & N D & -23 \\
\hline-20 & $\mathrm{NA}$ & $\mathrm{NA}$ & NA & N A & $N \AA$ & -29 & -25 & & & & & & & & & & \\
\hline $\begin{array}{l}-34 \\
-27 \\
+69\end{array}$ & $\begin{array}{l}\text { NA } \\
\text { NA } \\
\text { NA }\end{array}$ & $\begin{array}{l}\text { NA } \\
N A \\
N A\end{array}$ & $\begin{array}{l}\text { NA } \\
\text { N A } \\
\text { N A }\end{array}$ & $\begin{array}{l}\text { NA } \\
\text { NA } \\
\text { NA }\end{array}$ & $\begin{array}{l}\text { N A } \\
\text { N A } \\
\text { N A }\end{array}$ & $\begin{array}{l}-37 \\
-32 \\
+71\end{array}$ & $\begin{array}{r}-33 \\
-26 \\
+88\end{array}$ & & & & & & & & & & \\
\hline $\begin{array}{ll}-2 & 0 \\
-13 \\
-21 \\
-14\end{array}$ & $\begin{array}{l}\text { NA } \\
\text { NA } \\
\text { NA } \\
\text { NA }\end{array}$ & $\begin{array}{l}\text { NA } \\
\text { NA } \\
\text { N A } \\
\text { NA }\end{array}$ & $\begin{array}{l}-27 \\
-18 \\
-27 \\
-20\end{array}$ & $\begin{array}{l}-24 \\
-14 \\
-24 \\
-18\end{array}$ & $\begin{array}{l}-35 \\
-25 \\
-35 \\
-28\end{array}$ & $\begin{array}{l}-28 \\
-17 \\
-28 \\
-18\end{array}$ & $\begin{array}{l}-20 \\
-11 \\
-20 \\
-11\end{array}$ & $\begin{array}{l}-71 \\
-55 \\
-71 \\
-60\end{array}$ & $\begin{array}{l}-47 \\
-27 \\
-46 \\
-33\end{array}$ & $\begin{array}{l}-46 \\
-26 \\
-46 \\
-32\end{array}$ & & & & & & & \\
\hline $\begin{array}{r}-11 \\
0\end{array}$ & $\begin{array}{l}\text { NA } \\
\text { NA }\end{array}$ & $\begin{array}{l}\text { NA } \\
\text { N A }\end{array}$ & $\begin{array}{l}-02 \\
+07\end{array}$ & $\mid \begin{array}{l}-04 \\
+06\end{array}$ & $\begin{array}{l}\text { NA } \\
\text { NA }\end{array}$ & $\begin{array}{l}\mathrm{NA} \\
\mathrm{NA}\end{array}$ & $\begin{array}{l}\text { N A } \\
\text { NA }\end{array}$ & $\begin{array}{l}\text { N A } \\
\text { N A }\end{array}$ & \begin{tabular}{|l|} 
NA \\
NA A
\end{tabular} & $\begin{array}{l}\text { NA } \\
\text { NA }\end{array}$ & $\begin{array}{l}\mathrm{NA} \\
\mathrm{NA}\end{array}$ & $\begin{array}{l}N A \\
N A\end{array}$ & {$\left[\begin{array}{ll}-1 & 5 \\
-03 & 3\end{array}\right.$} & $\mid \begin{array}{rl}-1 & 1 \\
0 & 0\end{array}$ & $\begin{array}{ll}-0 & 1 \\
+1 & 0\end{array}$ & & \\
\hline
\end{tabular}

- NA - Thermal treatment not applied

* - L(1) - Longitudinal (Hole Distance)

* L Li) - Longituding

* - T(4) - Transu 
TABLE 6. PROCESS M-EXAMPLES OF DIMENSIONAL RESTORATION

THERMAL TREATMENTS FOR AM-355 TO PRODUCE EXPANSION FOR OFFSETTING CUMULATIVE SHRINKAGE

\begin{tabular}{|c|c|c|c|c|c|c|c|c|c|c|c|c|c|}
\hline \multirow[b]{3}{*}{ Heat } & \multirow[b]{3}{*}{ Material } & \multirow[b]{3}{*}{ Dimension } & \multirow[b]{3}{*}{ Prior Condition } & \multicolumn{10}{|c|}{ Dimensional Change from As-Received Condition. Mils/Inch } \\
\hline & & & & \multirow[b]{2}{*}{\begin{tabular}{|c|}
$\begin{array}{c}\text { Prior } \\
\text { Condition }\end{array}$ \\
\end{tabular}} & \multicolumn{4}{|c|}{$\begin{array}{c}\text { (In Sequence Applied) } \\
\text { Dimensional Restoration Thermal } \\
\text { Treatment Experiment }\end{array}$} & \multicolumn{3}{|c|}{$\begin{array}{c}\text { Next } \\
\text { Braze Cycle }\end{array}$} & \multicolumn{2}{|c|}{$\begin{array}{c}\text { Dimensional } \\
\text { Restoration } \\
\text { Thermal } \\
\text { Treatment } \\
\text { Experiment }\end{array}$} \\
\hline & & & & & \begin{tabular}{|l} 
After Equal. \\
$3 \mathrm{Hr} 1400 \mathrm{~F}$
\end{tabular} & $\begin{array}{c}\text { Plus } \\
\text { Sub-cool } \\
\end{array}$ & $\begin{array}{c}\text { After Trigger } \\
\text { Anneal } 1 \mathrm{Hr} \\
1710 \mathrm{~F} \\
\end{array}$ & $\begin{array}{c}\text { Plus } \\
\text { Sub-cool }\end{array}$ & $\begin{array}{l}\text { After } \\
\text { Braze }\end{array}$ & $\begin{array}{c}\text { Plus } \\
\text { Sub-cool } \\
\end{array}$ & $\begin{array}{c}\text { Plus } \\
\text { Temper }\end{array}$ & $\begin{array}{l}\text { After Trigger } \\
\text { Anneal l Hr } \\
1710 \mathrm{~F}\end{array}$ & $\begin{array}{c}\text { Plus } \\
\text { Sub-cool }\end{array}$ \\
\hline 27154 & $\begin{array}{l}\text { AM-355 Rolled Bar } \\
13 / 4 \text { in } \\
\text { Dia' } \times 9 \text { in }\end{array}$ & Longitudinal & 3rd Braze + Sub-cool & -14 & -03 & -02 & $\mathrm{~N} \AA$ & NA & -67 & -18 & NA & ND & -05 \\
\hline 27268 & $\begin{array}{l}\text { AM-355 Bottom } \\
\text { Plate for 218-Cell } \\
\text { Blanket Array }\end{array}$ & $\begin{array}{l}\text { Longitudinal } \\
\text { Transverse }\end{array}$ & $\begin{array}{l}\text { 4th Braze + Sub-cool } \\
4 \text { th Braze + Sub-cool }\end{array}$ & $\begin{array}{l}-10 \\
-10\end{array}$ & $\begin{array}{l}-07 \\
-02\end{array}$ & $\begin{array}{l}-05 \\
-02\end{array}$ & $\begin{array}{l}\text { NA } \\
\text { NA }\end{array}$ & $\begin{array}{l}\text { NA } \\
\text { NA }\end{array}$ & & & & & \\
\hline 26818 & $\begin{array}{l}\text { AM-355 Top Plate } \\
\text { for Seed Grid }\end{array}$ & $\begin{array}{l}\text { Longrtudinal } \\
\text { Transverse }\end{array}$ & $\begin{array}{l}\text { 11th Braze + Sub-cool } \\
11 \text { th Braze + Sub-cool }\end{array}$ & $\begin{array}{l}-08 \\
-15\end{array}$ & $\begin{array}{l}\text { NA } \\
\text { N A }\end{array}$ & $\begin{array}{l}\text { N A } \\
\text { NA }\end{array}$ & $\begin{array}{l}\text { ND } \\
\text { ND }\end{array}$ & $\begin{array}{l}+03 \\
-03\end{array}$ & & & & & \\
\hline 26818 & $\begin{array}{l}\text { AM-355 Bottom } \\
\text { Plate for Seed }\end{array}$ & $\begin{array}{l}\text { Longitudinal } \\
\text { Transverse }\end{array}$ & $\begin{array}{l}\text { 11th Braze + Sub-cool } \\
11 \text { th Braze + Sub-cool }\end{array}$ & $\begin{array}{ll}-13 \\
-21\end{array}$ & $\begin{array}{l}\text { NA } \\
\text { NA }\end{array}$ & $\begin{array}{l}\text { NA } \\
\text { NA }\end{array}$ & $\begin{array}{l}\text { ND } \\
\text { ND }\end{array}$ & $\begin{array}{r}00 \\
-10\end{array}$ & & & & & \\
\hline
\end{tabular}

NOTES: N.D. - Thermal treatment applied, but dimensional change not determined. N.A. - Thermal treatment not applied. 


\begin{tabular}{|c|c|c|c|c|c|c|c|c|}
\hline \multirow[b]{3}{*}{ Heat } & \multirow[b]{3}{*}{ Material } & \multirow[b]{3}{*}{ Type of Specimen } & \multirow[b]{3}{*}{ Dimension } & \multicolumn{5}{|c|}{ Dimensional Change from Starting Condition, Mils/Inch } \\
\hline & & & & Starting Condition & Firs & Cycle & Seco & d Cycle \\
\hline & & & & $\begin{array}{l}\text { (After Stabilization } \\
\text { Thermal* Treatment) }\end{array}$ & $\begin{array}{l}\text { After } \\
\text { Braze }\end{array}$ & $\begin{array}{c}\text { Plus } \\
\text { Sub-cool }\end{array}$ & $\begin{array}{l}\text { After } \\
\text { Braze }\end{array}$ & $\begin{array}{c}\text { Plus } \\
\text { Sub-cool }\end{array}$ \\
\hline 27205 & $\begin{array}{l}\text { AM-355 Plate } \\
3 / 4 \text { in. }\end{array}$ & $\begin{array}{l}\text { Dilatometer } 1 / 4 \text { in. } \\
\text { dia. } \times 2 \text { in. }\end{array}$ & Transverse & 0.0 & -2.4 & -0.7 & -3.3 & -1.6 \\
\hline $7 \mathrm{C} 601$ & $\begin{array}{l}\text { LC, LN AM-350 } \\
\text { Plate } 3 / 4 \text { in. }\end{array}$ & $\begin{array}{l}\text { Dilatometer } 1 / 4 \text { in. } \\
\text { dia. } \times 2 \text { in. }\end{array}$ & Transverse & 0.0 & -2.0 & -0.8 & -3.3 & -2.0 \\
\hline
\end{tabular}

* NOTE: The high-temperature stabilization thermal treatment consisted of heating for 6 hours at $2150 \mathrm{~F}$ in vacuum followed by a sub-zero cool for 3 hours at $-100 \mathrm{~F}$.

TABLE 8. PROCESS A-DIMENSIONAL CHANGE TESTS ON BAR AND PLATE SPECIMENS VERSUS BRAZE CYCLES

\begin{tabular}{|c|c|c|c|c|c|c|c|c|c|}
\hline Heat & Material & $\begin{array}{c}\text { As-Received } \\
\text { Condition } \\
\end{array}$ & Dimension & $\begin{array}{c}\text { As: } \\
\text { Received } \\
\end{array}$ & $\begin{array}{c}\text { Dimensior } \\
\text { After lst } \\
\text { Braze } \\
\end{array}$ & $\begin{array}{l}\text { 1 Cha. fr fr } \\
\text { After 2nd } \\
\text { Braze } \\
\end{array}$ & $\begin{array}{c}\text { m As-Recei } \\
\text { After 3rd } \\
\text { Braze } \\
\end{array}$ & $\begin{array}{c}\text { d Conditio } \\
\text { After 4th } \\
\text { Braze } \\
\end{array}$ & $\begin{array}{c}\text { Mils/Inch } \\
\text { After 5th } \\
\text { Braze } \\
\end{array}$ \\
\hline NX0895 & $\begin{array}{l}\mathrm{NiCrFe} \text { Alloy } 600 \\
\text { Plate } 3 / 4 \text { in } \times 9 \text { in. } \\
\times 9 \text { in }\end{array}$ & Annealed & $\begin{array}{l}\text { Long (Hole Distance, Y) } \\
\text { Trans (Hole Distance, X) }\end{array}$ & $\begin{array}{lll}0 & 0 \\
0 & 0\end{array}$ & $\begin{array}{l}-0.2 \\
+0.1\end{array}$ & $\begin{array}{l}-0.2 \\
+0.1\end{array}$ & $\begin{array}{l}-0.2 \\
-0.1\end{array}$ & $\begin{array}{l}-0.1 \\
-0.1\end{array}$ & $\begin{array}{r}-0.3 \\
0.0\end{array}$ \\
\hline NXI675 & $\begin{array}{l}\mathrm{NiCr} F \text { Alloy } 600 \text { Bar } \\
1 \mathrm{l} / 4 \text { in Dia } \times 9 \text { in }\end{array}$ & Annealed & Long (Hole Distance, $\mathrm{X}$ ) & 00 & +0.1 & +02 & -0.1 & +01 & +0.1 \\
\hline
\end{tabular}


TABLE 9. PROCESS M- FLATNESS OF BAR AND PLATE SPECIMENS

VERSUS BRAZE CYCLES

Flatness Within Total Indicated Range, Inches

\begin{tabular}{|c|c|c|c|c|c|c|c|c|c|c|}
\hline Heat & Material & $\begin{array}{c}\text { As-Received } \\
\text { Condition } \\
\end{array}$ & $\begin{array}{c}\text { As } \\
\text { Received } \\
\end{array}$ & $\begin{array}{c}\text { After lst } \\
\text { Braze } \\
\text { with } \\
\text { Sub-cool } \\
\end{array}$ & $\begin{array}{c}\text { After 2nd } \\
\text { Braze } \\
\text { with } \\
\text { Sub-cool } \\
\end{array}$ & $\begin{array}{c}\text { After 3rd } \\
\text { Braze } \\
\text { with } \\
\text { Sub-cool } \\
\end{array}$ & $\begin{array}{l}\text { After Equalize } \\
\text { With Sub-cool } \\
\end{array}$ & $\begin{array}{c}\text { After Trigger } \\
\text { Anneal with } \\
\text { Sub-cool } \\
\end{array}$ & $\begin{array}{c}\text { After Solution } \\
\text { Treatment with } \\
\text { Sub-cool } \\
\end{array}$ & $\begin{array}{c}\text { After 4th } \\
\text { Braze } \\
\text { with } \\
\text { Sub-cool }\end{array}$ \\
\hline 27154 & $\begin{array}{l}\text { AM-355 Rolled Bar } \\
13 / 4 \text { in Dia } \times 9 \text { in }\end{array}$ & $\mathrm{Eq} \& \mathrm{OT}$ & 0008 & 0005 & 0004 & 0016 & 0008 & $\mathrm{NA}$ & $\mathrm{NA}$ & 0005 \\
\hline 27205 & $\begin{array}{l}\text { AM-355 Plate } \\
3 / 4 \text { in } \times 9 \text { in } \times 9 \text { in }\end{array}$ & $\mathbb{E q} \& O T$ & 0006 & 0004 & 0009 & 0008 & 0009 & $\mathrm{~N} \mathrm{~A}$ & $\mathrm{NA}$ & 0009 \\
\hline $7 \mathrm{C} 547$ & $\begin{array}{l}\text { XLC AM-350 Rolled Bar } \\
13 / 4 \mathrm{in} \times 13 / 4 \mathrm{in} \\
\times 9 \text { in }\end{array}$ & Eq $\&$ OT & 0003 & 0002 & 0007 & 0003 & 0011 & $\mathrm{NA}$ & 0009 & $\mathrm{~N} A$ \\
\hline $7 \mathrm{C} 601$ & $\begin{array}{l}\text { LC, LN AM-350 Plate } \\
5 / 8 \mathrm{in} \times 15 \text { in } \times 24 \mathrm{in}\end{array}$ & $\mathrm{Eq} \& \mathrm{OT}$ & 0017 & 0024 & 0018 & $\mathrm{~N} \mathrm{~A}$ & 0040 & 0061 & 0030 & $\mathrm{~N} \mathrm{~A}$ \\
\hline 27433 & $\begin{array}{l}\text { M2. Tool Steel Plate } \\
3 / 4 \text { in } \times 9 \text { in } \times 9 \text { in }\end{array}$ & $\begin{array}{l}\text { Over- } \\
\text { Tempered }\end{array}$ & 0002 & 0007 & 0013 & 0018 & 0015 & NA & $\mathrm{NA}$ & 0010 \\
\hline H17033 & $\begin{array}{l}\text { M2 Tool Steel Plate } \\
5 / 8 \text { in } \times 24 \text { in } \times 24 \text { in } \\
\text { Cross Rolled }\end{array}$ & $\begin{array}{l}\text { Fully } \\
\text { Annealed }\end{array}$ & 0015 & 0080 & 0056 & $\mathrm{NA}$ & 0040 & & & \\
\hline
\end{tabular}

NOTES: N.A. - Thermal treatment not applied.

Eq-Equalized

OT - Over.Tempered 


\begin{tabular}{|c|c|c|c|c|c|c|c|c|c|c|c|c|c|}
\hline \multirow[b]{2}{*}{ Heat } & \multirow[b]{2}{*}{ Material } & \multirow[b]{2}{*}{$\begin{array}{c}\text { As- } \\
\text { Received } \\
\text { Condition } \\
\end{array}$} & \multicolumn{11}{|c|}{ Flatress Within Total Indicated Range. Inches } \\
\hline & & & $\begin{array}{c}\text { As- } \\
\text { Received }\end{array}$ & $\begin{array}{c}\text { After lst } \\
\text { Braze } \\
\text { with } \\
\text { Sub-cool } \\
\end{array}$ & $\begin{array}{l}\text { After 2nd } \\
\text { Braze } \\
\text { with } \\
\text { Sub-cool } \\
\end{array}$ & $\begin{array}{c}\text { After 3rd } \\
\text { Braze } \\
\text { with } \\
\text { Sub-cool } \\
\end{array}$ & $\begin{array}{l}\text { After 4th } \\
\text { Braze } \\
\text { with } \\
\text { Sub-cool } \\
\end{array}$ & $\begin{array}{l}\text { After 5th } \\
\text { Braze } \\
\text { with } \\
\text { Sub-cool } \\
\end{array}$ & $\begin{array}{c}\text { After 6th } \\
\text { Braze } \\
\text { with } \\
\text { Sub-cool } \\
\end{array}$ & $\begin{array}{c}\text { After I1th } \\
\text { Braze } \\
\text { with } \\
\text { Sub-cool } \\
\end{array}$ & $\begin{array}{c}\text { After } \\
\text { Equalize } \\
\text { with } \\
\text { Sub-cool } \\
\end{array}$ & $\begin{array}{c}\text { After } \\
\text { Solution } \\
\text { Treat with } \\
\text { Sub-cool } \\
\end{array}$ & $\begin{array}{c}\text { After } \\
\text { Trigger } \\
\text { Anreal with } \\
\text { Sub-cool } \\
\end{array}$ \\
\hline 27268 & $\begin{array}{l}\text { AM-355 Top Plate for } \\
218-C \text { ell Blanket Ar- } \\
\text { ray } 1 / 2 \text { in } \times 12 \text { in } \\
\times 12 \mathrm{~m}\end{array}$ & Eq \& OT & 0002 & N D & 0027 & 0058 & 0036 & NA & N A & NA & 0044 & 0065 & \\
\hline 27268 & $\begin{array}{l}\text { AM-355 Bottom Plate } \\
\text { for } 218 \text {-Cell Blanket } \\
\text { Array } 1 / 2 \mathrm{in} \times 12 \mathrm{in} \\
\times 12 \mathrm{in}\end{array}$ & $\mathrm{Eq} \& \mathrm{OT}$ & 0003 & N D & 0030 & 0031 & 0019 & N A & NA & $\mathrm{NA}$ & 0023 & 0037 & \\
\hline 26818 & $\begin{array}{l}\text { AM- } 355 \text { Top Plate for } \\
\text { Seed Grid } 3 / 8 \mathrm{in} \\
\times 11 \mathrm{~m} \times 12 \mathrm{in}\end{array}$ & Eq \& OT & 0003 & 0020 & ND & ND & ND & 0066 & 0088 & 0229 & N $\AA$ & N $\AA$ & 0318 \\
\hline 26818 & $\begin{array}{l}\text { AM-355 Bollom Plate } \\
\text { for Seed Grid } 3 / 8 \mathrm{in} \\
\times 11 \mathrm{in} \times 12 \mathrm{in}\end{array}$ & Eq \& OT & 0002 & 0030 & ND & N D & ND & 0047 & 0063 & 0109 & NA & NA & 0217 \\
\hline 27205 & 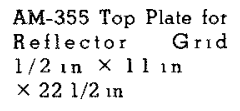 & Eq\&OT & 0001 & 0044 & & & & & & & & & \\
\hline 27205 & $\begin{array}{l}\text { AM- } 355 \text { Bottom Plate } \\
\text { for Reflector Grid } \\
1 / 2 \mathrm{in} \times 11 \mathrm{in} \\
\times 22 \mathrm{l} / 2 \mathrm{nn}\end{array}$ & Eq \& OT & 0007 & 0042 & & & & & & & & & \\
\hline 26818 & $\begin{array}{l}\text { AM-355 Top Plate for } \\
\text { Blanket Grid } 7 / 16 \mathrm{in} \\
\times 211 / 2 \mathrm{in} \\
\times 221 / 2 \mathrm{in}\end{array}$ & Eq \& OT & 0008 & 0080 & & & & & & & & & \\
\hline 26818 & $\begin{array}{l}\text { AM-355 Bottom Plate } \\
\text { for Blanket Grid } \\
7 / 16 \mathrm{nn} \times 211 / 2 \mathrm{in} \\
\times 221 / 2 \mathrm{mn}\end{array}$ & Eq \& OT & 0005 & 0085 & & & & & & & & & \\
\hline
\end{tabular}

NOTE: N.D. - Thermal treatment applied, but flatness not determined

N.A - Thermal treatment not applied 
TABLE 11. PROCESS A-FLATNESS OF BAR AND PLATE SPECIMENS VERSUS BRAZE CYCLES

\begin{tabular}{|c|c|c|c|c|c|c|c|c|}
\hline \multirow[b]{2}{*}{ Heat } & \multirow[b]{2}{*}{ Material } & \multirow[b]{2}{*}{$\begin{array}{c}\text { As-Received } \\
\text { Condition } \\
\end{array}$} & \multicolumn{6}{|c|}{ Flatness Within Total Indicated Range, Inches } \\
\hline & & & As-Received & $\begin{array}{l}\text { After lst } \\
\text { Braze }\end{array}$ & $\begin{array}{c}\text { After 2nd } \\
\text { Braze } \\
\end{array}$ & $\begin{array}{c}\text { After } 3 \text { rd } \\
\text { Braze } \\
\end{array}$ & $\begin{array}{c}\text { After } 4 \text { th } \\
\text { Braze } \\
\end{array}$ & $\begin{array}{c}\text { After } 5 \text { th } \\
\text { Braze } \\
\end{array}$ \\
\hline NX0895 & $\begin{array}{l}\mathrm{NiCrFe} \text { Alloy } 600 \text { Plate } \\
3 / 4 \text { in. } \times 9 \text { in. } \times 9 \text { in. }\end{array}$ & Annealed & 0.003 & 0.004 & 0.005 & 0.004 & 0.005 & 0.005 \\
\hline NX1675 & $\begin{array}{l}\mathrm{NiCrFe} \text { Alloy } 600 \text { Bar } \\
11 / 4 \text { in. Dia } \times 9 \text { in. }\end{array}$ & Annealed & 0.005 & 0.001 & 0.001 & 0.002 & 0.002 & 0.002 \\
\hline
\end{tabular}


TABLE 12. CHEMISTRY AND HEAT TREATMENT INFORMATION

ON MATERIALS INVESTIGATED

\begin{tabular}{|c|c|c|c|c|c|c|c|c|c|c|c|c|c|c|}
\hline Heat & 23326 & 27154 & 27205 & 27268 & 26818 & 7C547 & 7C598 & 7C599 & $7 \mathrm{C} 600$ & $7 \mathrm{C} 601$ & 27433 & H17033** & NX0895 & NX 1675 \\
\hline Alloy & AM-355 & AM-355 & AM-355 & AM-355 & AM-355 & AM-350 & AM-350 & AM-350 & AM-350 & AM-350 & M2 Tool Stl & M2 Tool Stl & Alloy 600 & Alloy 600 \\
\hline Form & $\begin{array}{l}\text { Rolled Bax } \\
13 / 8 \text { in. Dia. }\end{array}$ & $\begin{array}{l}\text { Rolled Bar } \\
13 / 4 \text { in. Dia. }\end{array}$ & $\begin{array}{l}\text { Plate } \\
3 / 4 \mathrm{in.}\end{array}$ & $\begin{array}{l}\text { Plate } \\
3 / 4 \text { in }\end{array}$ & $\begin{array}{l}\text { Plate } \\
3 / 4 \text { in. } 1\end{array}$ & $\begin{array}{c}\text { XLC } \\
\text { Rolled Bar } \\
13 / 4 \text { in. } \times 13 / 4 \text { in. }\end{array}$ & $\begin{array}{c}\text { LC, LN } \\
\text { Rolled Bar } \\
17 / 8 \text { in } \times 17 / 8 \text { in. }\end{array}$ & $\begin{array}{c}\text { LC. LN } \\
\text { Rolled Bar } \\
17 / 8 \text { in } \times 17 / 8 \text { in. }\end{array}$ & $\begin{array}{l}\text { LC. IN } \\
\text { Plate } \\
3 / 4 \text { in. }\end{array}$ & $\begin{array}{l}\text { LC. LN } \\
\text { Plate } \\
3 / 4 \text { in }\end{array}$ & $\begin{array}{l}\text { Plate } \\
3 / 4 \text { in. }\end{array}$ & $\begin{array}{l}\text { Plate } \\
3 / 4 \text { in. }\end{array}$ & $\begin{array}{l}\text { Plate } \\
3 / 4 \text { in. }\end{array}$ & $\begin{array}{c}\text { Rolled } \\
\text { Bar } \\
1 \text { 1/4 in. Dia. }\end{array}$ \\
\hline$\% \mathrm{C}$ & 013 & 013 & 0107 & 0114 & 011 & 0028 & 0055 & 0058 & 0048 & 0053 & 082 & 081 & 009 & 007 \\
\hline$\% \mathrm{Mn}$ & 095 & 093 & 096 & 094 & 081 & 061 & 079 & 080 & 082 & 074 & 023 & 025 & 027 & 024 \\
\hline $\begin{array}{l}\% \mathrm{P} \\
\% \mathrm{~S}\end{array}$ & - & 0023 & 0020 & 0024 & 0021 & 0008 & 0009 & 0009 & 0009 & 0008 & 0023 & 0016 & - & - \\
\hline $\begin{array}{l}\% \mathrm{~S} \\
\% \mathrm{~S}_{1}\end{array}$ & - & 0004 & 0010 & 0011 & 0014 & 0014 & 0013 & 0013 & 0014 & 0015 & 0002 & 0008 & 0007 & 0007 \\
\hline $\begin{array}{l}\% \mathrm{~S}_{1} \\
\% \mathrm{Cr}\end{array}$ & 025 & 019 & 023 & 023 & 024 & 041 & 037 & 037 & 036 & 036 & 039 & 031 & 026 & 025 \\
\hline$\% \mathrm{Cr}$ & 1550 & 1530 & 1358 & 1564 & 1510 & & 1619 & 1616 & 1633 & 1638 & 406 & 427 & 1604 & 1476 \\
\hline $\begin{array}{l}\% \mathrm{~N}_{1} \\
\% \mathrm{Fe}\end{array}$ & 430 & 433 & 422 & 417 & 422 & 429 & 450 & 449 & 441 & 444 & 010 & 017 & 7473 & 7638 \\
\hline $\begin{array}{l}\% \mathrm{Fe} \\
\% \mathrm{Mo}\end{array}$ & $\overline{275}$ & $\overline{283}$ & $\overline{285}$ & $\overline{2} \overline{75}$ & 58 & $\overline{9}$ & 287 & - & - & & & & 840 & 813 \\
\hline $\begin{array}{l}\% \mathrm{Mo} \\
\% \mathrm{Cu}\end{array}$ & -2 & - & 285 & 275 & $\begin{array}{l}285 \\
010\end{array}$ & 281 & 287 & 286 & 277 & 274 & 486 & 503 & - & - \\
\hline$\% \mathrm{~N}_{2}$ & 010 & 0095 & 0089 & $\overrightarrow{0084}$ & $\begin{array}{l}010 \\
0078\end{array}$ & $\overline{0.75}$ & $0 \overline{064}$ & - & - & - & 009 & 005 & 018 & 014 \\
\hline$\% \mathrm{C}^{2}$ & - & - & - & - & $\stackrel{0.078}{-}$ & 0054 & 0064 & 0068 & 0062 & 0064 & - & $\overrightarrow{2}$ & - & - \\
\hline$\% \mathrm{~B}$ & - & - & - & - & $=$ & $\begin{array}{l}0000 \\
0005\end{array}$ & $\overline{-}$ & - & - & - & 015 & 013 & - & - \\
\hline$\% \mathrm{~W}$ & - & - & - & - & - & - & - & $\bar{z}$ & $\overline{-}$ & - & $6 \overline{07}$ & $6 \overline{42}$ & - & - \\
\hline$\% \mathrm{Sn}_{1}$ & - & - & - & - & - & - & - & - & - & - & 0012 & - & - & - \\
\hline$\% \mathrm{~V}$ & - & - & - & - & - & - & - & - & - & - & 175 & 198 & - & - \\
\hline $\begin{array}{l}\text { Procure- } \\
\text { ment } \\
\text { Spec }\end{array}$ & - & AMS5743C & - & - & AMS5549B & - & - & - & - & - & $\sigma$ & - & ASTM B-168 & $\begin{array}{c}\text { MIL- } \\
\text { N-6710 }\end{array}$ \\
\hline $\begin{array}{l}\text { Procure- } \\
\text { ment Con- } \\
\text { dithon }\end{array}$ & Eq $\&$ OT & Eq \& OT & Eq \& OT & Eq \& OT & Eq \& OT & $\mathrm{Eq}_{\mathrm{q}} \& \mathrm{OT}$ & Eq \& OT & Eq \& OT & Eq \& OT & Eq \& OT & $\begin{array}{c}\text { Over } \\
\text { Tempered }\end{array}$ & $\begin{array}{c}\text { Fully } \\
\text { Annealed }\end{array}$ & Annealed & Annealed \\
\hline
\end{tabular}

NOTES: *Ordening data in purchase order was also provided.

Delled with equal reductions in the longitudinal and transverse directions. LC-Low Carbon

LN-Low Nitrogen

Eg-Equalized

OT-Over-Tempered 


\section{TABLE 13. AVERAGE DIMENSIONAL CHANGES FROM THE ORIGINAL AS-RECEIVED DIMENSION OF THE AM-355 BRAZING FIXTURE PLATES}

\begin{tabular}{|c|c|c|c|c|c|}
\hline \multirow[b]{3}{*}{ Heat } & \multirow{3}{*}{$\begin{array}{l}\text { Condition Measured } \\
\text { (With Hot Lift-Off } \\
\text { and Flattening } \\
\text { As Indicated) }\end{array}$} & \multicolumn{4}{|c|}{ Dimensional Change from Original (Mils Per Inch) } \\
\hline & & \multicolumn{2}{|c|}{ Top Plate } & \multicolumn{2}{|c|}{ Bottom Plate } \\
\hline & & Longitudinal & Transverse & Longitudinal & Transverse \\
\hline \multirow[t]{4}{*}{$\begin{array}{l}\text { Set } \\
\text { No. } 1 \\
26818\end{array}$} & lst Braze $(b)+$ Sub-cool $(c)$ & -0.3 & +0.1 & Not Measured & \\
\hline & 2nd Braze $(b)+S u b-c o o l(c)$ & -1.2 & -1.2 & +0.3 & +0.5 \\
\hline & $\begin{array}{l}\text { 3rd Braze }(\mathrm{b})+\text { Sub-cool } \\
+ \text { Restorative Cycle }(\mathrm{a}),(\mathrm{c})\end{array}$ & -2.4 & -2.9 & -0.3 & -1.3 \\
\hline & $\begin{array}{l}\text { 4th Braze }(\mathrm{b})+\text { Sub-cool } \\
+ \text { Restorative Cycle }(\mathrm{a}),(\mathrm{c})\end{array}$ & -3.6 & -5.1 & -0.7 & -2.2 \\
\hline \multirow[t]{2}{*}{$\begin{array}{l}\text { Set } \\
\text { No. } 2 \\
26818\end{array}$} & lst Braze $(b)+\operatorname{Sub-cool}(d)$ & +1.7 & +1.3 & +1.7 & +1.4 \\
\hline & 2nd Braze(b) + Sub-cool(d) & +1.7 & +0.5 & +1.6 & +1.0 \\
\hline $\begin{array}{l}\text { Set } \\
\text { No. } 3 \\
26818\end{array}$ & lst Braze $(b)+S u b-c^{\prime} o l^{(e)}$ & -0.3 & -0.3 & +0.8 & +0.7 \\
\hline
\end{tabular}

NOTES: (a) Restorative treatment-1710F for 1 hour +3 hours at $-100 F$.

(b) Hot lift-off of the grid at about 200F was used during the cool from the brazing temperature.

(c) Flattening of the fixture plates in a hydraulic press at room temperature was used each time after the braze and before the sub-cool, after the sub-cool, and after the restorative cycle.

(d) No flattening of the fixture plates was used.

(e) Flattening of the fixture plates was used after the sub-cool only. 
TABLE 14. DIMENSIONAL DIFFERENCE BETWEEN THE INITIAL AND LAST BRAZE CYCLE MEASUREMENTS (PROCESS A-NiCrFe

ALLOY 600 BRAZING FIXTURES)

\section{Orientation}

With Respect to No. of

Fixture Direction Rolling Direction

$\mathrm{BA}-2$
$\mathrm{~S} / \mathrm{N}-01$

$\mathrm{BA}-2$

A and B Parallel

Cycles

16

Top Mils

Plate

Mils/Inch

$+4.0^{*}$

$+0.3$

Bottom Plate

$\mathrm{S} / \mathrm{N}-01$

BA -1

$\mathrm{S} / \mathrm{N}-02$

BA-1

$\mathrm{S} / \mathrm{N}-02$
C and D Perpendicular

A and B Parallel

$\mathrm{C}$ and D

Perpendicular
16

$+1.5^{* *}$

$+0.1$

$+2.0^{* *}$

$+0.1$

$23+12.5^{*}$

$+0.8$

$+4.0^{*}$

$+0.3$

23

$+0.1$

$+5.5^{* *}$

$+0.3$
Mils Mils/Inch

$+2.0 * \quad .+0.1$

*Average Value $=\left(\frac{A+B}{2}\right)_{\text {Final }}-\left(\frac{A+B}{2}\right)_{\text {Initial }}$

**Average Value $=\left(\frac{C+D}{2}\right)_{\text {Final }}-\left(\frac{C+D}{2}\right)_{\text {Initial }}$ 